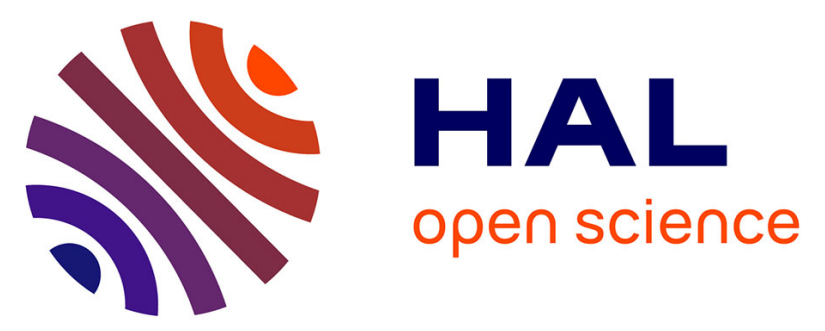

\title{
Zinc, aluminum and group 3 metal complexes of sterically demanding naphthoxy-pyridine ligands: Synthesis, structure, and use in ROP of racemic lactide and $\beta$-butyrolactone
}

Yulia Chapurina, Thierry Roisnel, Jean-François Carpentier, Evgeny Kirillov

\section{To cite this version:}

Yulia Chapurina, Thierry Roisnel, Jean-François Carpentier, Evgeny Kirillov. Zinc, aluminum and group 3 metal complexes of sterically demanding naphthoxy-pyridine ligands: Synthesis, structure, and use in ROP of racemic lactide and $\beta$-butyrolactone. Inorganica Chimica Acta Reviews, 2015, 431, pp.161-175. 10.1016/j.ica.2014.11.002 . hal-01091458

HAL Id: hal-01091458

https://hal-univ-rennes1.archives-ouvertes.fr/hal-01091458

Submitted on 5 Dec 2014

HAL is a multi-disciplinary open access archive for the deposit and dissemination of scientific research documents, whether they are published or not. The documents may come from teaching and research institutions in France or abroad, or from public or private research centers.
L'archive ouverte pluridisciplinaire HAL, est destinée au dépôt et à la diffusion de documents scientifiques de niveau recherche, publiés ou non, émanant des établissements d'enseignement et de recherche français ou étrangers, des laboratoires publics ou privés. 


\section{For the Table of content entry}

n<smiles>CC1OC(=O)C(C)OC1=O</smiles>

n

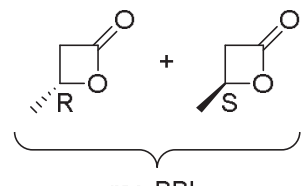

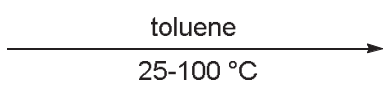

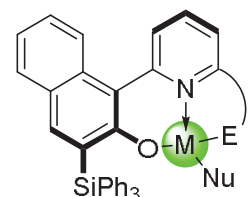

$E=O, N$

$M=Z n$

Ac

Sc, Y, La

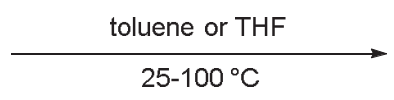

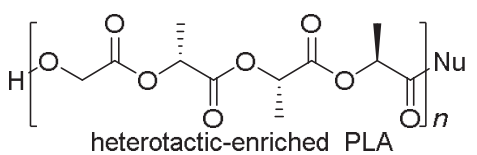

$\left(P_{\text {r }}\right.$ up to 0.80$)$

TOF up to $1840 \mathrm{~mol} \cdot \mathrm{mol}^{-1} \cdot \mathrm{h}^{-1}$

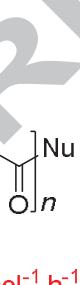

Zinc, aluminum and group 3 metal complexes supported by tridentate naphthoxy-pyridine ligands were prepared and used as initiators/catalysts for the ring-opening polymerization of racemic-lactide and racemic- $\beta$-butyrolactone, affording heterotactic- enriched PLAs and atactic PHBs, respectively. 
Zinc, Aluminum and Group 3 Metal Complexes of Sterically Demanding NaphthoxyPyridine Ligands: Synthesis, Structure, and Use in ROP of racemic Lactide and $\beta$ Butyrolactone

Yulia Chapurina, ${ }^{a}$ Thierry Roisnel, ${ }^{\mathrm{b}}$ Jean-François Carpentier*,a and Evgeny Kirillov*,a

${ }^{a}$ Organometallics: Materials and Catalysis and ${ }^{b}$ Centre de Diffractométrie X, Institut des Sciences Chimiques de Rennes, UMR 6226 CNRS-Université de Rennes 1, F-35042 Rennes Cedex, France

Abstract: New potentially tridentate, bulky ortho- $\mathrm{Ph}_{3}$ Si-substituted naphthol-pyridine proligands a-f were synthesized and introduced onto zinc, aluminum and group 3 metal centers $(\mathrm{M}=\mathrm{Sc}, \mathrm{Y}, \mathrm{La})$ using straightforward one-step alkane or amine elimination protocols. The solid-state structures of these mononuclear zinc $(\mathbf{1 a}, \mathbf{1 c}, \mathbf{1 d}, \mathbf{2 c}$ and $\mathbf{2 e})$ and aluminum (3c) complexes were determined by single-crystal X-ray diffraction studies, while the solution structures were established using ${ }^{1} \mathrm{H},{ }^{13} \mathrm{C}\left\{{ }^{1} \mathrm{H}\right\}$ and ${ }^{29} \mathrm{Si} /{ }^{29} \mathrm{Si}\left\{{ }^{1} \mathrm{H}\right\}$ (when appropriate) NMR spectroscopy. For all complexes, only one species (isomer) of $C_{1}$ symmetry was observed by NMR spectroscopy in the broad temperature range. Most of these complexes are effective initiators for the ring-opening polymerization (ROP) of racemic lactide (rac-LA) at 25-100 ${ }^{\circ} \mathrm{C}$, affording poly(lactides)s (PLAs) generally with unimodal dispersities and molecular weights in good agreement with calculated values. An yttrium complex (4e) proved the most active $\left(\mathrm{TOF}=1840 \mathrm{~mol}(\mathrm{LA}) \cdot \mathrm{mol}(\mathrm{Y})^{-1} \cdot \mathrm{h}^{-1}\right.$ at $\left.25^{\circ} \mathrm{C}\right)$ and yielded heterotactic-enriched PLAs $\left(P_{\mathrm{r}}\right.$ up to 0.80$)$ in toluene, while atactic PHBs are formed in the ROP of racemic $\beta$ butyrolactone ( $r a c-B B L)$ under the same conditions.

\footnotetext{
*Corresponding authors: Fax: (+33)(0)223-236-939. E-mail: evgueni.kirillov@univrennes1.fr; jean-francois.carpentier@univ-rennes1.fr
} 


\section{Introduction}

Stereocontrolled ring-opening polymerization (ROP) of racemic cyclic esters (e.g., lactide (rac-LA) and $\beta$-butyrolactone (rac-BBL)), mediated by discrete organometallic precursors, has been the subject of numerous studies in the last years. ${ }^{1}$ Polymerization of these renewable monomers under appropriate conditions can lead to polymers exhibiting a wide range of microstructures (iso/hetero(syndio)/atactic, and also stereoblock and gradient), which may confer, in each specific case, high crystallinity, improved elastomeric properties and controlled biodegradability. The ligand nature (geometry) plays a pivotal role in the polymerization stereocontrol, even if stereoselection during coordination/insertion of the monomer onto a metal center occurs via a chain-end control (CEM) rather than an enantiomorphic site control mechanism (SCM), which is the more "natural" process for chirality transfer onto a growing polymeric chain.

In our ongoing survey of new ancillaries for engineering of potent catalysts/initiators for stereocontrolled ROP of cyclic esters, we have designed a bis(naphthoxy)pyridine ligand platform (Scheme 1). ${ }^{3,4}$ The non-coplanar orientation of the bridging pyridine and adjacent naphthoxy groups within the latter system, upon stereoselective coordination with group 4 metals ( $\mathrm{Ti}, \mathrm{Zr}$ and $\mathrm{Hf}$ ), can give rise to two distinct geometries, namely, $C_{\mathrm{s}}$-symmetric (mesolike) and $C_{2}$-symmetric (rac-like) isomers. ${ }^{5}$ This interconversion between two geometries is anticipated to exert some special influence on the stereocontrollablity of the metal complexes towards the polymerizations of cyclic esters such as rac-LA and rac-BBL, leading to polyesters with different tacticities (e.g., atactic or hetero/syndiotactic). Also, if such interconversion would occur on the timescale of polymerization propagation ("oscillating" behavior), it could lead to stereoblock architectures (i.e., macromolecules enchaining segments of different tacticities). In fact, reversible interconversion between such $C_{\mathrm{s}^{-}}$and $C_{2^{-}}$ symmetric isomers of group 4 metal complexes has been demonstrated to take place in 
toluene solution with a moderate activation barrier $\left(\Delta \mathrm{G}_{298}^{\neq}=13.8-15.6 \mathrm{kcal} \cdot \mathrm{mol}^{-1}\right)$. Yet, in our previous attempts intended to extend this coordination chemistry to groups 3 ( $\mathrm{Sc}, \mathrm{Y}$ and La) and $13(\mathrm{Al})$ metals, for each compound, solely the isomer exhibiting the $C_{\mathrm{s}}$-symmetric coordination of the ligand has been observed and isolated. ${ }^{5}$ For all of these different complexes, interconversion between the $C_{\mathrm{s}^{-}}$and a putative $C_{2}$-symmetric isomers was not observed in solution using VT NMR spectroscopic studies. The latter behavior may stem either from a much higher interconversion barrier (kinetic control), intrinsic to such bis(naphthoxy)pyridine complexes of groups 3 and 13 metals, or from basic instability of the associated $C_{2}$-isomer (thermodynamic control). When used as initiators/precatalysts in ROP of $r a c$-LA and $r a c$-BBL, these group 3 metal bis(naphthoxy)pyridine complexes were found to be moderately heteroselective and syndioselective, respectively, while the aluminum complexes appeared to be non-stereoselective. ${ }^{5}$

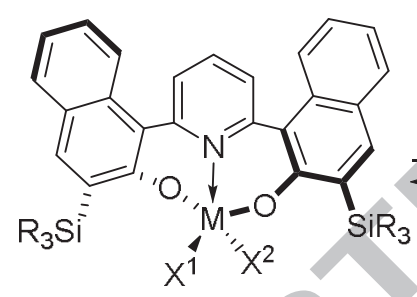

$\mathrm{C}_{2}$-symmetric ligand

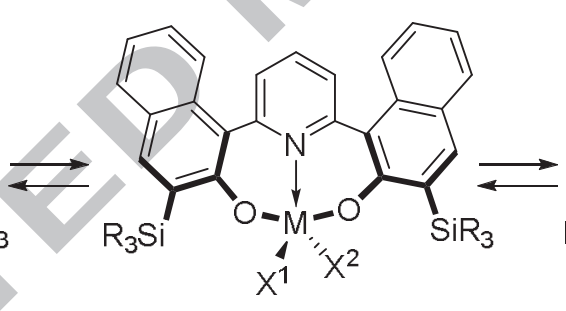

$C_{\mathrm{s}}$-symmetric ligand

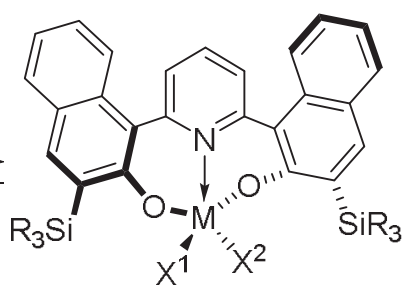

$\mathrm{C}_{2}$-symmetric ligand

$$
\begin{gathered}
M=\text { group } 4 \text { metal }(\mathrm{Ti}, \mathrm{Zr}, \mathrm{Hf}) \\
X^{1}=\mathrm{X}^{2}=\mathrm{CH}_{2} \mathrm{Ph}, \mathrm{NMe}_{2} \\
M=\text { group } 3 \text { metal }(\mathrm{Sc}, \mathrm{Y}, \mathrm{La}) \\
X^{1}=\mathrm{N}(\mathrm{SiHMe})_{2}, X^{2}=\mathrm{THF} \\
M=\operatorname{group~} 13 \text { metal }(\mathrm{Al}) \\
X^{1}\left(X^{2}\right)=\mathrm{Me}, \mathrm{OiPr}, \mathrm{OCH}(\mathrm{Me})\left(\mathrm{CH}_{2}\right)_{n} \mathrm{CO}_{2} \mathrm{R}^{\prime}\left(\mathrm{R}^{\prime}=\mathrm{Me}, \mathrm{Pr} ; \mathrm{n}=0,1\right)
\end{gathered}
$$

Scheme 1. $\mathrm{Ph}_{3} \mathrm{Si}$-substituted bis(naphthoxy)pyridine-based polymerization systems.

Thus, we decided to set up more flexible ligand platforms that combine the conformationally stable naphthoxy-pyridine scaffold and pending heteroatom-containing donating groups. We surmised that the implementation of these ligands would provide a less 
sterically rigid binding with metal center ${ }^{6}$ and would allow preparation of complexes featuring relatively easy dynamic interconversion between isomers of different geometries.

In this contribution, two main categories of asymmetrically substituted pyridinenaphthol proligands were considered (Scheme 2): (i) proligands a-d bearing $O$-based pendant donating groups, which would result in monoanionic $\{\mathrm{ONO}\}^{-}$ligand platforms, and (ii) proligands incorporating $\mathrm{N}$-based pendant donating groups for the synthesis of complexes with both monoanionic $\{\mathrm{ONN}\}^{-}$(e) and dianionic $\{\mathrm{ONN}\}^{2-}$ (f) ligand platforms. The synthesis of the corresponding complexes of zinc, aluminum and group 3 metals ( $\mathrm{Sc}, \mathrm{Y}$ and La) was investigated, and the obtained compounds were studied as initiators in the ROP of rac-LA and rac-BBL.
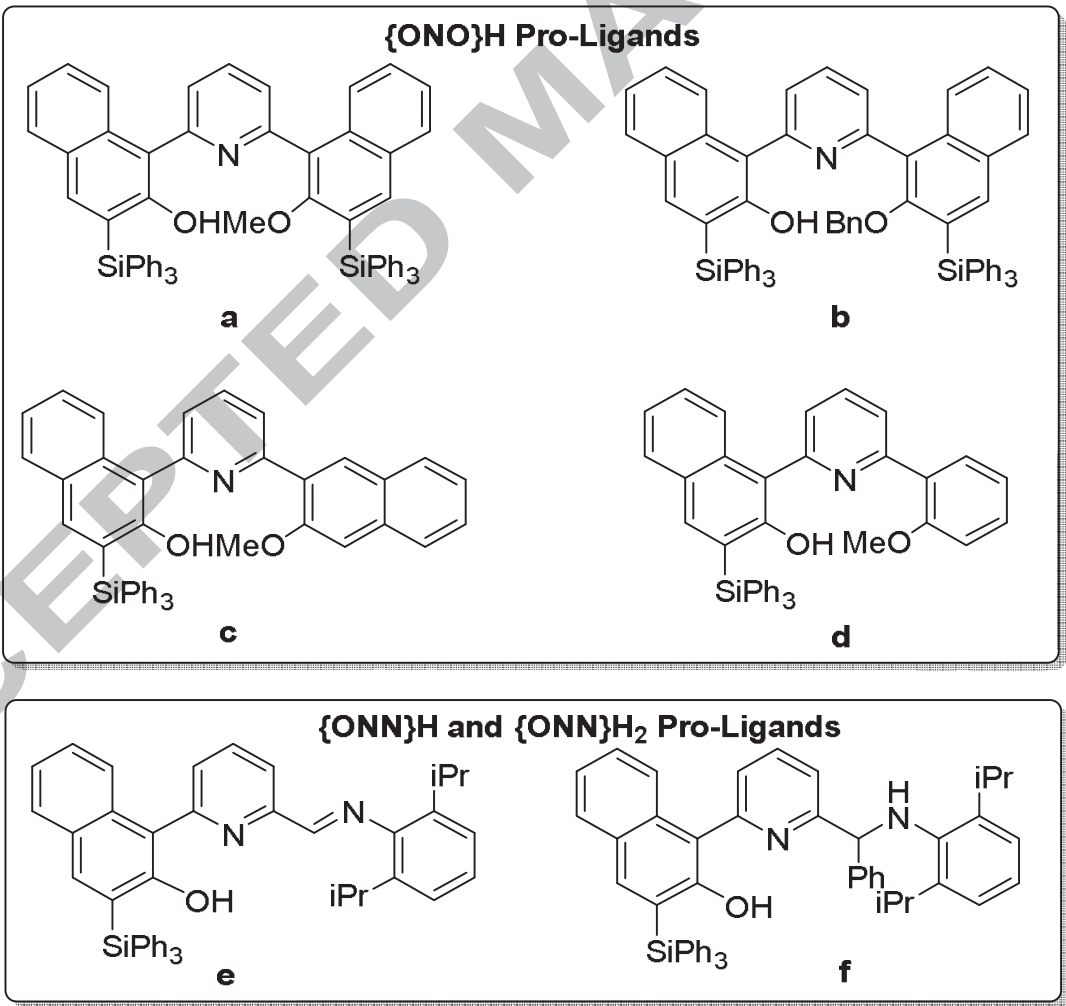

Scheme 2. Tridentate pyridine-linked naphthol-based proligands a-f used in this study.

\section{Results and Discussion}


Synthesis of Proligands. Asymmetric pyridine-linked proligands $\mathbf{a}$ and $\mathbf{b}$ were prepared starting from the diproteo bis(naphthol)pyridine proligand previously described by our group (Scheme 3). ${ }^{5 \mathrm{a}}$ The two-step procedure involves deprotonation of the latter precursor with $\mathrm{PhCH}_{2} \mathrm{~K}$ in THF followed by methylation or benzylation reaction with MeI or $\mathrm{BnBr} / \mathrm{Bu}_{4} \mathrm{NI}$ to afford $\mathbf{a}$ and $\mathbf{b}$, respectively. Analytically pure proligands were obtained after column chromatography in $49 \%$ and $46 \%$ yields, respectively.

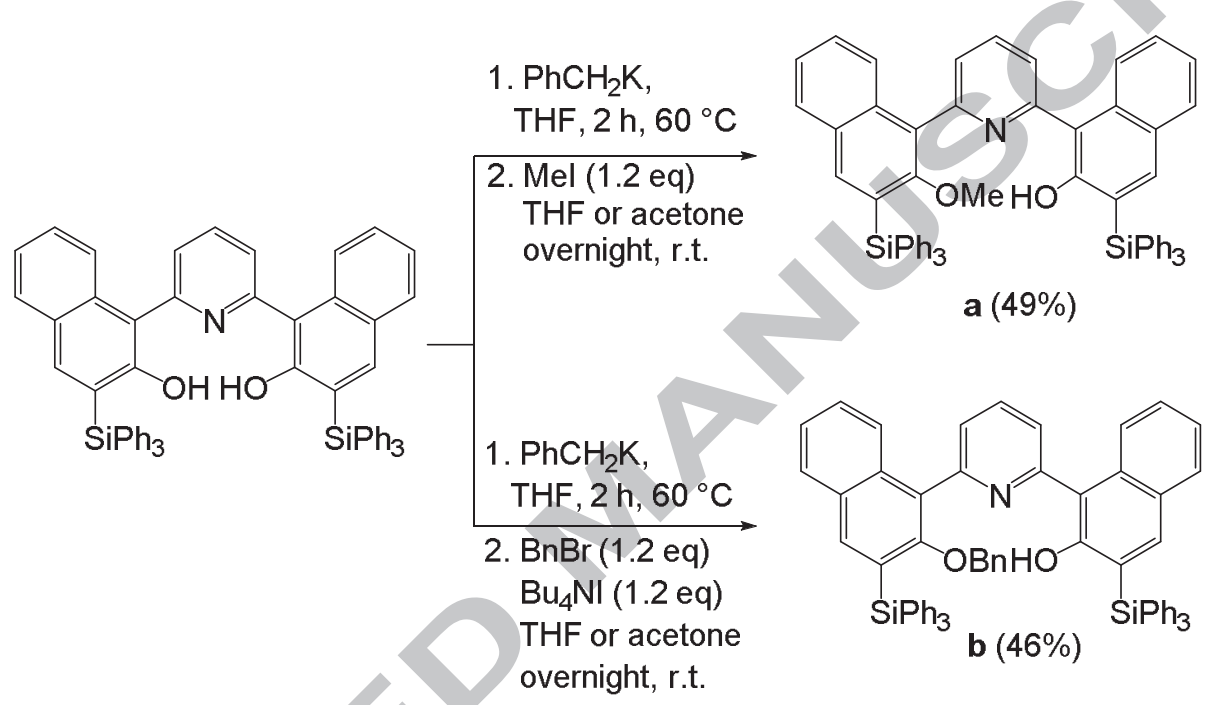

Scheme 3. Synthesis of proligands $\mathbf{a}$ and $\mathbf{b}$.

The synthesis of $\mathbf{c}$ and $\mathbf{d}$ was accomplished via Suzuki coupling between 2-bromo-6(2-(methoxymethoxy)-3-(triphenylsilyl)naphthalen-1-yl)pyridine (see the Experimental Section) and the corresponding boronic acid, followed by deprotection (Scheme 4). Both compounds were obtained in $66 \%$ and $94 \%$ yields, respectively, after recrystallization. 


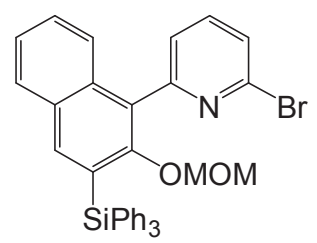

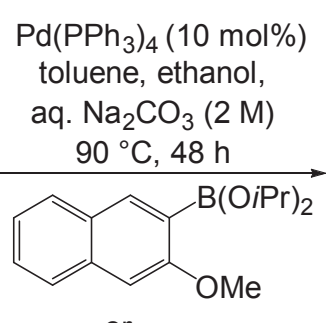

or<smiles>COc1ccccc1Br</smiles>

$\underset{\text { reflux, } 4 \mathrm{~h}}{\stackrel{\mathrm{HCl} / \mathrm{EtOH} / \mathrm{CHCl}_{3}}{\longrightarrow}}$<smiles>CCCCc1cc2ccccc2c(-c2cccc(-c3cc4ccccc4cc3OC)n2)c1O</smiles><smiles>COc1cccc(-c2cccc(-c3c(O)c([SbH])cc4ccccc34)n2)c1</smiles>

Scheme 4. Synthesis of proligands $\mathbf{c}$ and $\mathbf{d}$.

Compound e was obtained in $76 \%$ yield by a standard condensation of 6-(2-hydroxy3-(triphenylsilyl)naphthalen-1-yl)picolinaldehyde (see the Experimental Section) with 2,6diisopropylaniline (Scheme 5). Further reaction of isolated e with a 3-fold excess of $\mathrm{PhLi}$, followed by hydrolysis, gave compound $\mathbf{f}$ in $90 \%$ yield.<smiles>O=Cc1cccc(-c2c(O)c(SCc3ccccc3)cc3ccccc23)n1</smiles>

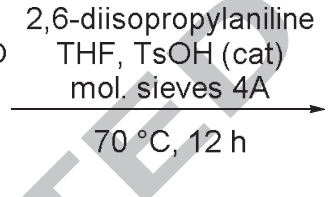
$70^{\circ} \mathrm{C}, 12 \mathrm{~h}$<smiles>CC(C)c1ccc(C=Nc2c(C(C)C)cccc2C(C)C)c(C(C)C)c1</smiles><smiles>CCC(C)c1cccc(C(C)C)c1NC(c1cccc(-c2c(O)c(S)cc3ccccc23)n1)C(C)C</smiles>

Scheme 5. Synthesis of proligands $\mathbf{e}$ and $\mathbf{f}$.

Proligands $\mathbf{a}-\mathbf{f}$ are stable compounds, readily soluble in aromatic hydrocarbons (benzene, toluene) and other common solvents $\left(\mathrm{CHCl}_{3}, \mathrm{CH}_{2} \mathrm{Cl}_{2}\right.$, THF). These compounds were fully characterized by ${ }^{1} \mathrm{H}$ and ${ }^{13} \mathrm{C}$ NMR spectroscopy, elemental analysis and X-ray crystallography (Figures S57 and Tables S1 and S2). 
Synthesis of Zinc, Aluminum and Group 3 Metal Complexes. The preparation of alkyl- and amido-zinc complexes supported by these bulky naphthoxy-based ligands was carried out by direct $\sigma$-bond metathesis of $\mathrm{ZnEt}_{2}$ and $\mathrm{Zn}\left[\mathrm{N}\left(\mathrm{SiMe}_{3}\right)_{2}\right]_{2}$, respectively, with proligands a-d. Generally, the reactions took place in toluene at room temperature, concomitantly eliminating 1 equiv of ethane or $\mathrm{HN}\left(\mathrm{SiMe}_{3}\right)_{2}$, respectively.

1. Ligands of ONO-type. Within the series of complexes of $\{\mathrm{ONO}\}^{-}$ligands (Scheme 2, top), both the corresponding ethyl-zinc (1a, 1c and 1d) and amido-zinc (2c and 2d) compounds were isolated in high yields. The reaction of $\mathbf{b}$ with $\mathrm{Zn}\left[\mathrm{N}\left(\mathrm{SiMe}_{3}\right)_{2}\right]_{2}$ appeared to be problematic, and mixtures of the desired complex $\mathbf{2} \mathbf{b}$ with the initial proligand were systematically obtained. The outcome of these tests did not change even upon heating at 80 ${ }^{\circ} \mathrm{C}$ over one week. The reasons for such reactivity remained unclear, and $\mathbf{1 b}$ was not isolated pure. The reaction of $\mathbf{b}$ with $\mathrm{Et}_{2} \mathrm{Zn}$ did not take place in benzene or toluene even upon reflux.

In a similar manner, dimethyl-aluminum complex $\mathbf{3 c}$ was prepared by treatment of the parent proligand with a small excess of $\mathrm{AlMe}_{3}$ in toluene at room temperature and isolated as a red crystalline solid in $88 \%$ yield (Scheme 6). Due to difficulties encountered for $\mathrm{Zn}$ and $\mathrm{Ln}$ (vide infra) chemistries, neither a nor $\mathbf{b}$ were tested with Al.

The complexes were characterized by NMR spectroscopy in solution and elemental analysis and X-ray crystallography in the solid state (vide infra). The ${ }^{1} \mathrm{H}$ and ${ }^{13} \mathrm{C}\left\{{ }^{1} \mathrm{H}\right\}$ NMR spectra of 1a, 1c, 1d, $2 \mathbf{c}, \mathbf{2 d}$ and $3 \mathbf{c}$ confirm the nature of the compounds. In particular, the ${ }^{13} \mathrm{C}$ NMR chemical shifts (less sensitive than ${ }^{1} \mathrm{H}$ signals to anisotropic effects quite likely in those complexes having multiple aromatic rings) for the $\mathrm{Zn}-\mathrm{CH}_{2} \mathrm{CH}_{3}(\delta-1.8$ and $11.8(\mathbf{1 a})$, -1.2 and $12.8(\mathbf{1 c}),-2.4$ and $12.3(\mathbf{1 d}) \mathrm{ppm}), \mathrm{Zn}-\mathrm{N}\left(\mathrm{SiMe}_{3}\right)_{2}(\delta 5.4(\mathbf{2 c}), 5.5(\mathbf{2 d})$ and $4.9(\mathbf{2 e})$ $\mathrm{ppm})$ and $\mathrm{Al}-\mathrm{Me}(\boldsymbol{\delta}-9.7(\mathbf{3 c})$ and $-14.2(\mathbf{3 e}) \mathrm{ppm})$ groups are in line with those reported in the literature for analogous Zn-ethyl, ${ }^{7} \mathrm{Zn}$-amido ${ }^{8}$ and Al-methyl ${ }^{4,5 b, c}$ complexes. These NMR data also all testify of the asymmetric nature of these complexes in solution. Due to the substantial bulkiness of the ligand scaffolds, some of the complexes (1a and 1d) exhibited a 
moderate fluxional behavior. Hence, the room-temperature ${ }^{1} \mathrm{H}$ NMR spectrum of $\mathbf{1 a}$ in toluene- $d_{8}$ (Figure S23) displayed a series of broadened signals due to fluxional dynamics arising from a hindered reorganization of the geometry (presumably, via reversible decoordination and rotation of the bulky MeO-naphthyl moiety and/or reciprocal reorganization of the adjacent naphthoxy and pyridine moieties). Upon lowering the temperature, all signals sharpened and a well-resolved NMR spectrum for this compound was recorded at $-20{ }^{\circ} \mathrm{C}$ (Figures S20-S22), consistent with the presence of a single $C_{1}$-symmetric species. For other compounds in this series, this reorganization process appeared to be more facile and the corresponding ${ }^{1} \mathrm{H}$ NMR spectra all displayed sharp resonances at room temperature (see the SI).

We also investigated the coordination of an $\{\mathrm{ONO}\}$ ligand on group 3 metals through aminolysis of $\operatorname{Ln}\left[\mathrm{N}\left(\mathrm{SiHMe}_{2}\right)_{2}\right]_{3} \mathrm{THF}(\mathrm{Ln}=\mathrm{Y}, \mathrm{La})$ with an equimolar amount of a. The reactions were monitored by ${ }^{1} \mathrm{H}$ NMR spectroscopy in toluene- $d_{8}$ at $25{ }^{\circ} \mathrm{C}$. Under these conditions, complete consumption of the proligand, accompanied with concomitant release of 1 equiv of $\mathrm{HN}\left(\mathrm{SiHMe}_{2}\right)_{2}$, was observed within $18 \mathrm{~h}$ for both yttrium and lanthanum. Unfortunately, the ${ }^{1} \mathrm{H}$ NMR spectra of both products appeared to remain very broad over the large temperature range -50 to $+80{ }^{\circ} \mathrm{C}$, and these NMR data were not conclusive as to the nature of the product(s) formed. Also, all attempts to crystallize these materials failed. Due to these difficulties, the coordination chemistry of other $\{\mathrm{ONO}\}$ ligands with group 3 metals was not further investigated. 


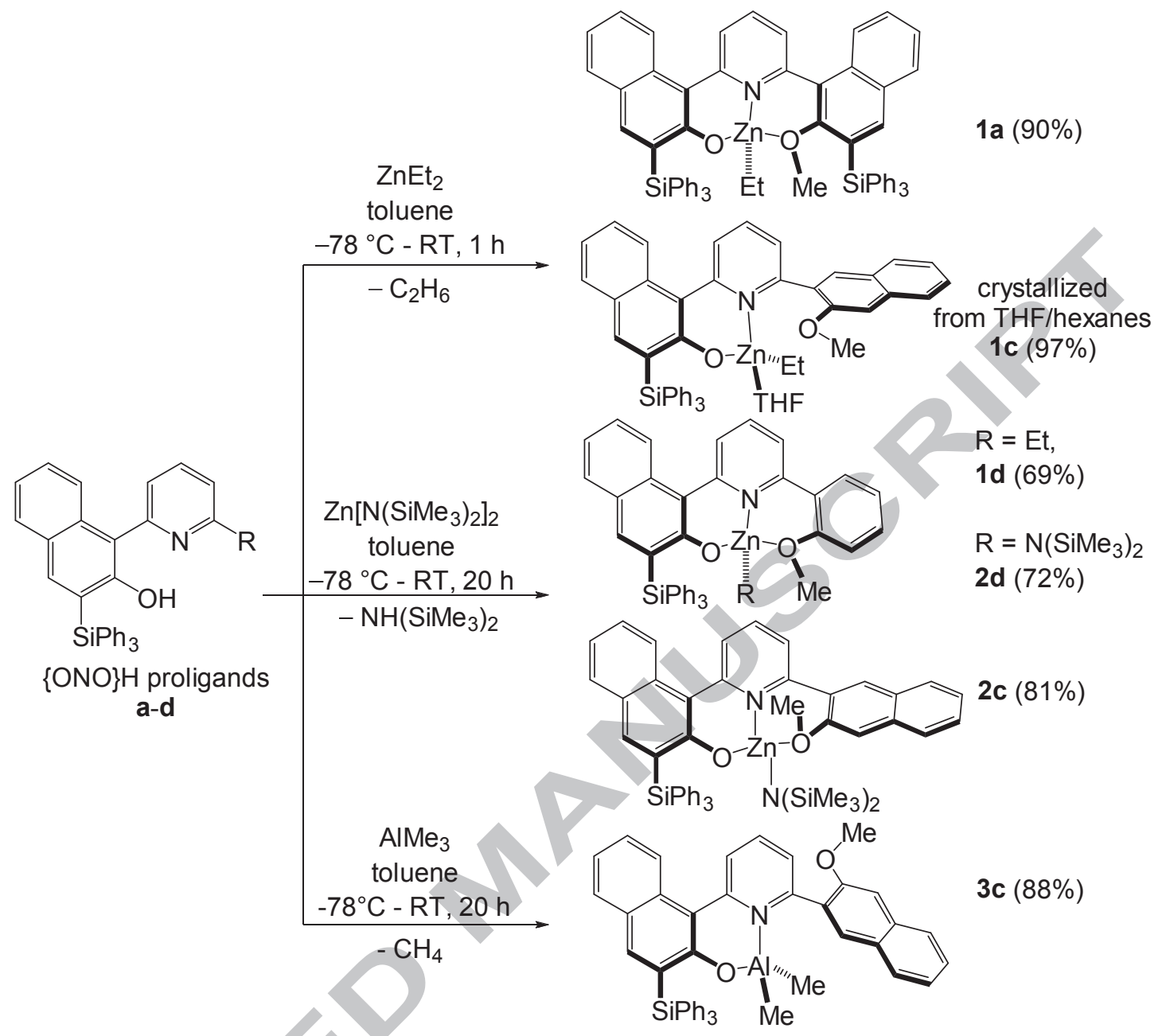

Scheme 6. Synthesis of $\{\mathrm{ONO}\}^{-}$complexes of $\mathrm{Zn}(\mathbf{1 a}-\mathbf{d}, \mathbf{2 d}$ and $\mathbf{2 c})$ and $\mathrm{Al}(\mathbf{3 c})$.

2. Ligands of ONN-type. Analogous reactivity studies were performed for the $\{\mathrm{ONN}\}$-type proligand $\mathbf{e}$ (Scheme 7). Reaction of e with 1 equiv of $\mathrm{Zn}\left[\mathrm{N}\left(\mathrm{SiMe}_{3}\right)_{2}\right]_{2}$ gave the desired complex 2e with high yield. On the other hand, using a similar protocol as that employed for the synthesis of $\mathbf{3 c}$, the reaction of $\mathbf{e}$ with 1 equiv of $\mathrm{AlMe}_{3}$ afforded after a standard workup, instead of the desired 3e, the monomethyl-aluminum complex 3e' containing a new dianionic $\{\mathrm{ONN}\}^{2-}$ ligand. This result is in line with previous observations made on the coordination of imino-based ligands on $\mathrm{AlMe}_{3}$, which typically resulted in nucleophilic addition of a methyl group on the $\mathrm{C}=\mathrm{N}$ bond. ${ }^{9}$ 
Reaction of e with 1 equiv of $\mathrm{Y}\left[\mathrm{N}\left(\mathrm{SiHMe}_{2}\right)_{2}\right]_{3} \mathrm{THF}$ successfully yielded the corresponding THF-free diamido compound 4e (Scheme 7).

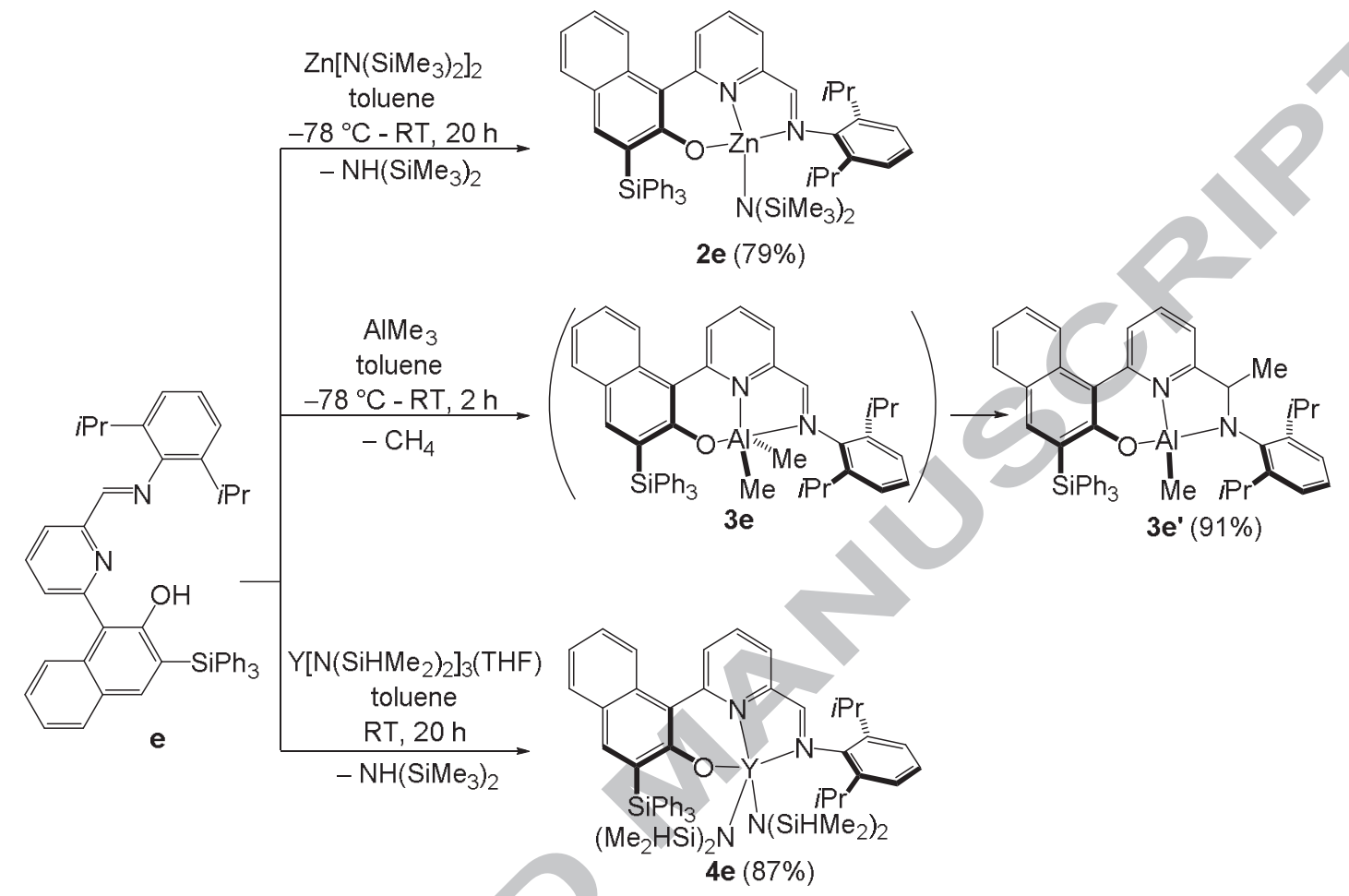

Scheme 7. Synthesis of $\{\mathrm{ONN}\}$ and $\{\mathrm{ONN}\}^{2-}$ complexes of $\mathrm{Zn}(\mathbf{2 e}), \mathrm{Al}(\mathbf{3 e}$ ') and $\mathrm{Y}(\mathbf{4 e})$.

Complexes 2e, 3e' and 4e were characterized by ${ }^{1} \mathrm{H},{ }^{13} \mathrm{C}\left\{{ }^{1} \mathrm{H}\right\}$ and ${ }^{29} \mathrm{Si}$ (for $4 \mathbf{e}$ ) NMR spectroscopy in solution, and elemental analysis and X-ray diffraction study (for 2e) in the solid state. The fluxional dynamic behavior observed for $\mathbf{2 e}$ and $\mathbf{4 e}$ in benzene solution (Fig. S32, S38 and S40) may arise from hindered rotation associated to the bulky diisopropylphenyl and amido groups. All three complexes featured asymmetric structures in solution, as revealed by ${ }^{1} \mathrm{H}$ and ${ }^{13} \mathrm{C}\left\{{ }^{1} \mathrm{H}\right\}$ NMR spectroscopy. For instance, the $i \operatorname{Pr}$ groups of the diisopropylphenyl groups gave rise to two sets of signals in the corresponding NMR spectra. In $4 \mathbf{e}$, the two $\mathrm{N}\left(\mathrm{SiHMe}_{2}\right)_{2}$ groups were also found non-equivalent and appeared as two sets of signals in the corresponding ${ }^{1} \mathrm{H},{ }^{13} \mathrm{C}$ and ${ }^{29} \mathrm{Si}$ NMR spectra (Figures S38, S39 and S42, respectively); those signals do not coalesce, even upon heating at $60{ }^{\circ} \mathrm{C}$. 
The amine elimination reactions between $\mathbf{f}$ and 1 equiv of $\operatorname{Ln}\left[\mathrm{N}(\mathrm{SiHMe})_{2}\right]_{3} \mathrm{THF}(\mathrm{Ln}=$ Sc, Y and La) were investigated (Scheme 8). The reactions took place at $50{ }^{\circ} \mathrm{C}$ overnight with complete consumption of the proligand and concomitant release of 2 equiv of $\mathrm{HN}\left(\mathrm{SiHMe}_{2}\right)_{2}$ to afford $\mathbf{5 f}(\mathrm{Y})$ and $\mathbf{6 f}(\mathrm{La})$. For the $\mathrm{Sc}$ analogue $\mathbf{4 f}$, an extended reaction time (one week) was required for completion of the reaction. This reactivity trend is in agreement with the larger ionic character of $\mathrm{Y}$ and $\mathrm{La}\left(\mathrm{Y}^{+3}(\mathrm{CN}=6): 0.90 \AA, \mathrm{La}^{+3}(\mathrm{CN}=6): 1.03 \AA\right)$ as compared to that of $\mathrm{Sc}\left(\mathrm{Sc}^{+3}(\mathrm{CN}=6): 0.75 \AA\right) .{ }^{10}$ After a standard workup, the monoamido complexes 4-5f of the dianionic $\{\mathrm{ONN}\}$-type ligand were isolated in good yields (67-83\%).
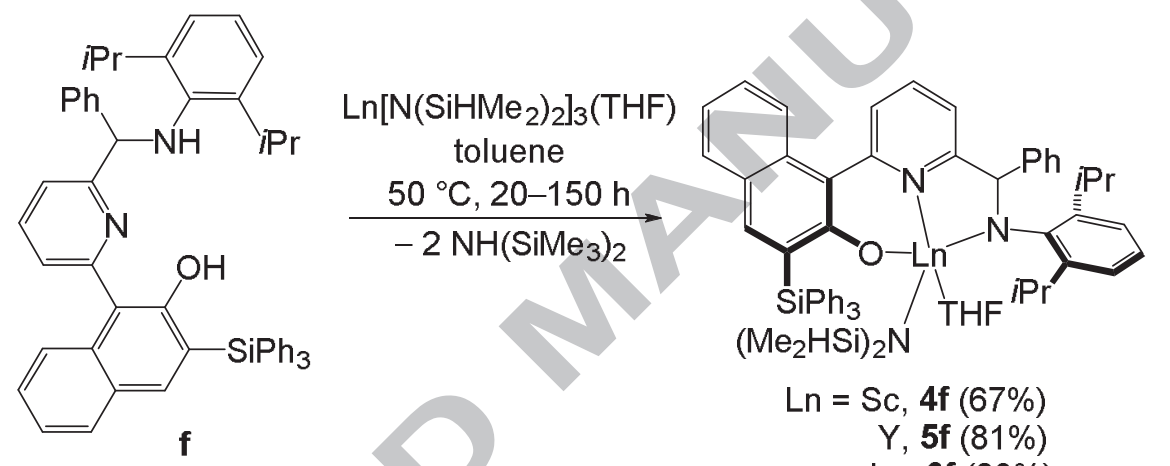

$$
\begin{array}{r}
\operatorname{Ln}=\mathrm{Sc}, \mathbf{4 f}(67 \%) \\
\text { Y, } 5 \mathbf{f}(81 \%) \\
\text { La, } 6 \mathbf{f}(83 \%)
\end{array}
$$

Scheme 8. Synthesis of $\{\mathrm{ONN}\}^{2-}$ complexes of Sc (4f), Y (5f) and La (6f).

These compounds are readily soluble in aromatic hydrocarbons (benzene, toluene) and in THF. The structures of these complexes were established on the basis of ${ }^{1} \mathrm{H},{ }^{13} \mathrm{C}\left\{{ }^{1} \mathrm{H}\right\}$, ${ }^{29} \mathrm{Si}\left\{{ }^{1} \mathrm{H}\right\}$ and ${ }^{29} \mathrm{Si}$ NMR spectroscopy and elemental analysis. By analogy with group 3 metal complexes of dianionic bis(naphthoxy)pyridine ligands, ${ }^{5 b}$ the mono-THF adducts $\mathbf{4 f - 6 f}$ are most probably mononuclear and five-coordinate in benzene or toluene solutions. The chemical shifts of the $\mathrm{SiH}$ moiety $\left(\delta 4.70-4.84 \mathrm{ppm}\right.$ at room temperature in $\left.\mathrm{C}_{6} \mathrm{D}_{6}\right)$ for $\mathbf{4 f}, \mathbf{5 f}$ and $\mathbf{6 f}$ and the ${ }^{1} J_{\mathrm{Si}-\mathrm{H}}$ coupling constants $(180,165$ and $163 \mathrm{~Hz}$, respectively) were found in the regular range of values, arguing against strong $\beta-\mathrm{Si}-\mathrm{H}^{\cdots} \mathrm{Ln}$ agostic interactions with the metal centers in solution. ${ }^{11}$ The structures of all complexes are asymmetric in solution over a broad 
temperature range, as judged from the ${ }^{1} \mathrm{H}$ NMR data obtained for $\mathbf{5 f}$ (Figure S51). Also, no interconversion between asymmetric species having different geometries was evidenced for the latter species by variable-temperature ${ }^{1} \mathrm{H}$ NMR spectroscopy. ${ }^{12}$

Solid-State Structures of Zinc and Aluminum Complexes. Single crystals of zinc and aluminum complexes suitable for X-ray diffraction analysis were obtained from the following mixtures: $\mathrm{C}_{6} \mathrm{H}_{6} /$ heptane $\left(\mathbf{1} \cdot 1.5 \mathrm{C}_{6} \mathrm{H}_{6},\right)$, THF/hexane (1c and $\mathbf{3} \mathbf{c}^{\cdot} \mathrm{C}_{4} \mathrm{H}_{8} \mathrm{O}$ ) and toluene/hexane $\left(\mathbf{1 a} \cdot 0.5 \mathrm{C}_{7} \mathrm{H}_{8}, \mathbf{2} \mathbf{c}\right.$ and $\left.\mathbf{2 e}\right)$. The crystallographic data of these complexes are summarized in Table S3 and important bond distances and angles are given in the corresponding Figures 1-6.

In the solid state, all the complexes feature a monomeric structure with the metal center in a distorted tetrahedral geometry. The common feature observed in these molecular structures lies in the non-coplanarity of the naphthoxy and pyridine planes. The twist angles between these two fragments range from 42.04 to $55.8^{\circ}$, which falls within the range of values (38.7-64.4 ${ }^{\circ}$ observed for related bis(naphthoxy)pyridine complexes of group 3 and 4 metals. $^{3,5}$

In zinc complexes 1a, 1d, 2c and 2e, the metal center lies in a (distorted) tetrahedral environment, coordinated by the tridentate ligands and the ethyl or bis(trimethylsilyl)amido group. In 1c, the ligand is only $\kappa^{2}$-coordinated by its $\mathrm{O}$ (naphthoxy) and $\mathrm{N}$ (pyridine) and the metal center is also four-coordinated by an additional THF molecule (instead of the ligand methoxy, in contrast to 1d). The $\mathrm{Zn}-\mathrm{O}$ (naphthoxy) (1.912(4)-1.979(3) $\AA$ ), $\mathrm{Zn}-\mathrm{N}$ (pyridine) $(2.037(3)-2.133(2) \quad \AA), \quad \mathrm{Zn}-\mathrm{C}($ ethyl $) \quad(1.956(3)-1.977(3) \quad \AA) \quad$ and $\quad \mathrm{Zn}-\mathrm{N}($ amido $)$ (1.9015(16)-1.902(3) $\AA$ ) bond lengths are in the range of, or are close to those observed in related compounds $\left(2.021(2)-2.029(2),{ }^{13} 1.962(2)-2.054(4),{ }^{7,8,14} 1.958(3)-1.981(2)^{7,14,15}\right.$ and 1.869(2)-1.920(4) $\AA^{8}{ }^{8}$ respectively). Noteworthy, the $\mathrm{Zn}-\mathrm{N}(\mathrm{imino})$ bond distance in $2 \mathrm{e}$ (2.162 (3) $\AA$ ) is $c a .0 .1 \AA$ longer than that reported for related compounds (1.872(1)-1.977(4) 
$\AA$ ). This elongation can probably be a result of a significant steric hindrance in $2 \mathbf{e}$.

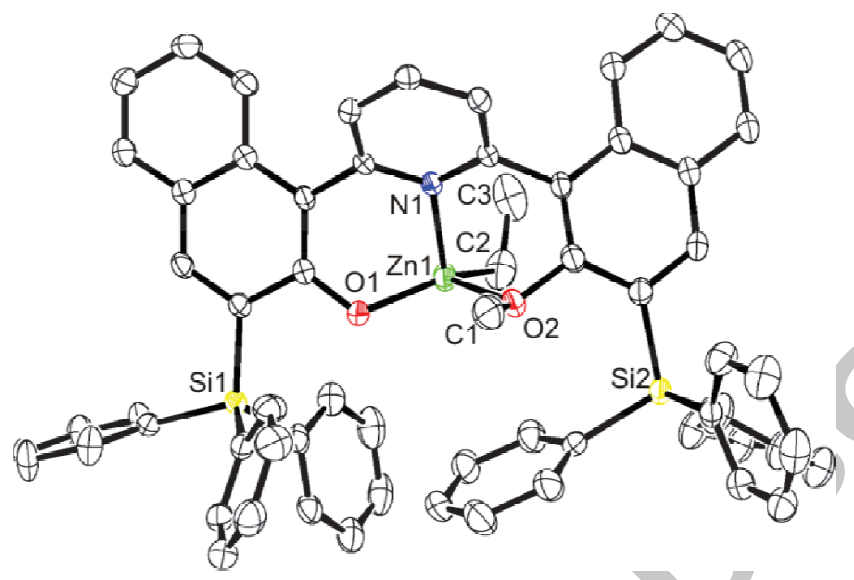

Figure 1. Solid-state molecular structure of $1 \mathbf{a} \cdot 0.5 \mathrm{C}_{7} \mathrm{H}_{8}$ (thermal ellipsoids drawn at $50 \%$ probability; all solvent molecules and hydrogen atoms are omitted for clarity). Selected bond distances $(\AA)$ and angles (deg): $\mathrm{Zn}(1)-\mathrm{O}(1), 1.912(4) ; \mathrm{Zn}(1)-\mathrm{O}(2), 2.238(4) ; \mathrm{Zn}(1)-\mathrm{N}(1)$, 2.103(2); $\mathrm{Zn}(1)-\mathrm{C}(2), \quad 1.956(3) ; \mathrm{Zn}(1)-\mathrm{C}(2)-\mathrm{C}(3), \quad 112.0(2) ; \mathrm{O}(1)-\mathrm{Zn}(1)-\mathrm{O}(2), \quad 97.2(2) ;$ $\mathrm{Zn}(1)-\mathrm{O}(2)-\mathrm{C}(1), 125.3(2) ; \mathrm{O}(1)-\mathrm{Zn}(1)-\mathrm{N}(1), 90.3(7) ; \mathrm{O}(2)-\mathrm{Zn}(1)-\mathrm{N}(1), 79.5(7) ; \mathrm{C}(2)-$ $\mathrm{Zn}(1)-\mathrm{N}(1), 116.55(11)$.

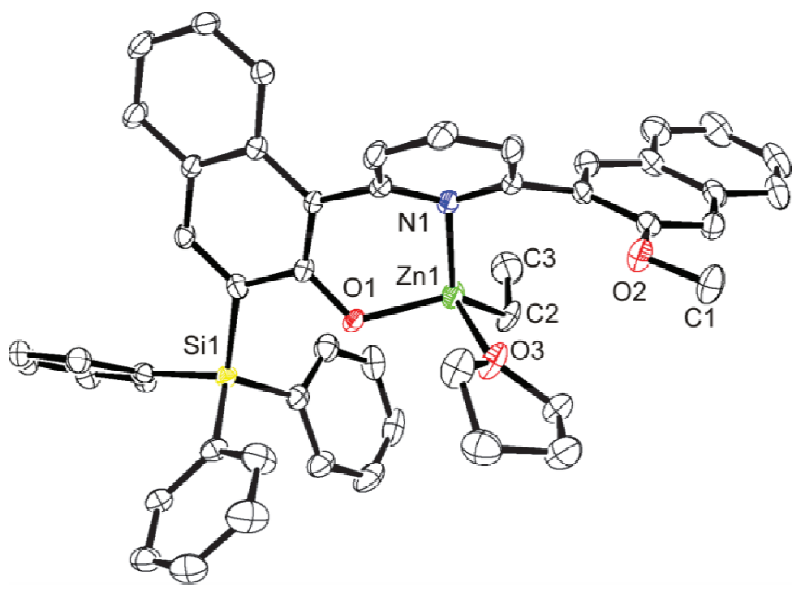


Figure 2. Solid-state molecular structure of $\mathbf{1 c}$ (thermal ellipsoids drawn at 50\% probability; all hydrogen atoms are omitted for clarity). Selected bond distances (Å) and angles (deg): $\mathrm{Zn}(1)-\mathrm{O}(1), 1.9386(18) ; \mathrm{Zn}(1)-\mathrm{N}(1), 2.133(2) ; \mathrm{Zn}(1)-\mathrm{C}(2), 1.977(3) ; \mathrm{Zn}(1)-\mathrm{O}(3), 2.138(2)$; $\mathrm{Zn}(1)-\mathrm{C}(2)-\mathrm{C}(3), 119.6(2) ; \mathrm{O}(1)-\mathrm{Zn}(1)-\mathrm{O}(3), 91.08(8) ; \mathrm{O}(3)-\mathrm{Zn}(1)-\mathrm{N}(1), 89.60(8) ; \mathrm{O}(1)-$ $\mathrm{Zn}(1)-\mathrm{N}(1), 91.23(8) ; \mathrm{C}(2)-\mathrm{Zn}(1)-\mathrm{N}(1), 133.03(11)$.

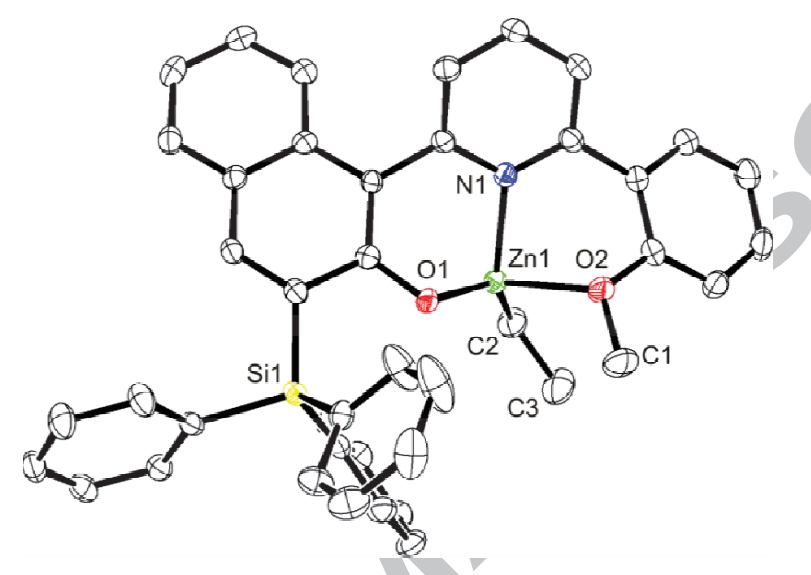

Figure 3. Solid-state molecular structure of $\mathbf{1 d}^{1} 1.5 \mathrm{C}_{6} \mathrm{H}_{6}$ (thermal ellipsoids drawn at $50 \%$ probability; all solvent molecules and hydrogen atoms are omitted for clarity). Selected bond distances ( $\mathrm{A})$ and angles (deg): $\mathrm{Zn}(1)-\mathrm{O}(1), \quad$ 1.9390(18); Zn(1)-O(2), 2.265(2); Zn(1)-N(1), 2.065(2); $\mathrm{Zn}(1)-\mathrm{C}(2), \quad 1.960(3) ; \mathrm{Zn}(1)-\mathrm{C}(2)-\mathrm{C}(3), 116.4(2) ; \mathrm{O}(1)-\mathrm{Zn}(1)-\mathrm{O}(2), \quad 95.52(8)$; $\mathrm{Zn}(1)-\mathrm{O}(2)-\mathrm{C}(1), \quad 116.23(18) ; \mathrm{O}(1)-\mathrm{Zn}(1)-\mathrm{N}(1), \quad 88.65(8) ; \mathrm{O}(2)-\mathrm{Zn}(1)-\mathrm{N}(1), \quad 79.05(8) ;$ $\mathrm{C}(2)-\mathrm{Zn}(1)-\mathrm{N}(1), 130.94(11)$. 


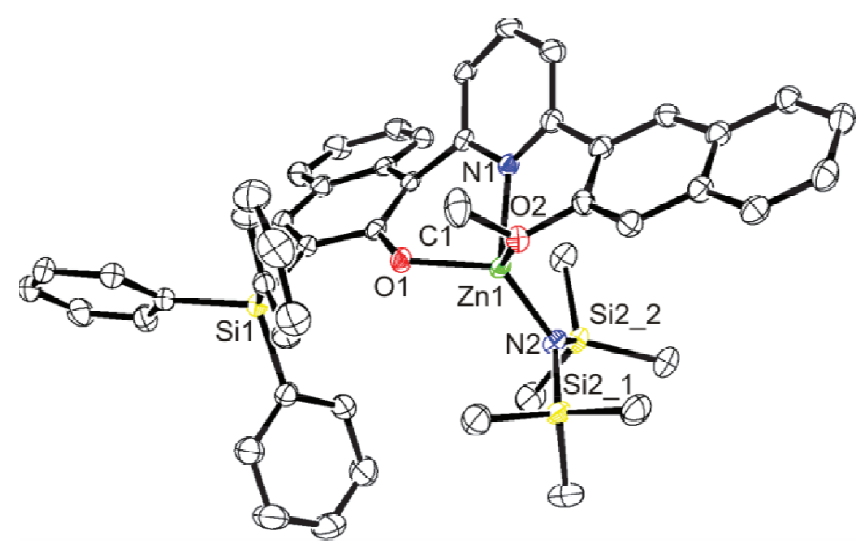

Figure 4. Solid-state molecular structure of $\mathbf{2 c}$ (thermal ellipsoids drawn at 50\% probability; all hydrogen atoms are omitted for clarity). Selected bond distances ( $)$ and angles (deg): $\mathrm{Zn}(1)-\mathrm{O}(1), 1.9363(13) ; \mathrm{Zn}(1)-\mathrm{O}(2), 2.1454(13) ; \mathrm{Zn}(1)-\mathrm{N}(1), 2.0422(16) ; \mathrm{Zn}(1)-\mathrm{N}(2)$, 1.9015(16); $\mathrm{N}(1)-\mathrm{Zn}(1)-\mathrm{N}(2), 131.71(7) ; \mathrm{O}(1)-\mathrm{Zn}(1)-\mathrm{O}(2), 97.65(5) ; \mathrm{Zn}(1)-\mathrm{O}(2)-\mathrm{C}(1)$, 118.08(12); $\mathrm{O}(1)-\mathrm{Zn}(1)-\mathrm{N}(1), \quad 90.57(6) ; \quad \mathrm{O}(2)-\mathrm{Zn}(1)-\mathrm{N}(1), \quad 84.98(6) ; \quad \mathrm{O}(1)-\mathrm{Zn}(1)-\mathrm{N}(2)$, 127.68(7), O(2)-Zn(1)-N(2), 112.96(6).

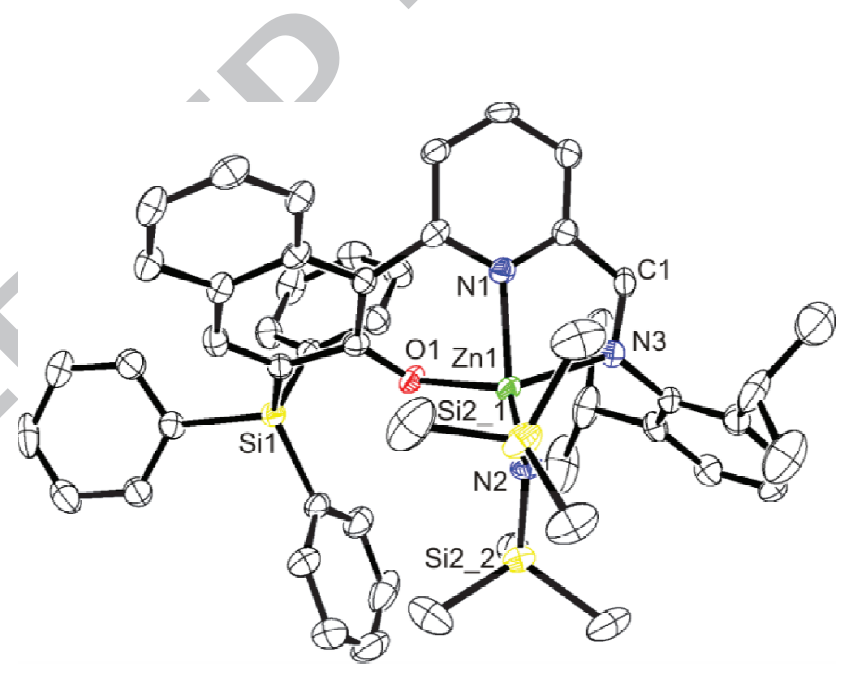

Figure 5. Solid-state molecular structure of 2e (thermal ellipsoids drawn at 50\% probability; all hydrogen atoms are omitted for clarity). Selected bond distances $(\AA)$ and angles (deg): $\mathrm{Zn}(1)-\mathrm{O}(1), 1.979(3) ; \mathrm{Zn}(1)-\mathrm{N}(1), 2.037(3) ; \mathrm{Zn}(1)-\mathrm{N}(2), 1.902(3) ; \mathrm{Zn}(1)-\mathrm{N}(3), 2.162(3) ;$ $\mathrm{N}(3)-\mathrm{C}(1), 1.276(5) ; \mathrm{N}(1)-\mathrm{Zn}(1)-\mathrm{N}(2), 130.35(13) ; \mathrm{O}(1)-\mathrm{Zn}(1)-\mathrm{N}(3), 119.03(11) ; \mathrm{Zn}(1)-$ 
$\mathrm{N}(3)-\mathrm{C}(1), \quad 111.2(3) ; \quad \mathrm{O}(1)-\mathrm{Zn}(1)-\mathrm{N}(1), \quad 84.80(12) ; \mathrm{N}(1)-\mathrm{Zn}(1)-\mathrm{N}(3), \quad 78.22(13) ; \quad \mathrm{O}(1)-$ $\mathrm{Zn}(1)-\mathrm{N}(2), 122.61(13), \mathrm{N}(2)-\mathrm{Zn}(1)-\mathrm{N}(3), 112.51(13)$.

The overall geometry and metal coordination environment in $\mathbf{3 c}$ are the same as those observed before in four-coordinated dimethyl-aluminum complexes of both bi- and tridentate $o$-Ph ${ }_{3} \mathrm{Si}$-substituted phenoxy-imino ligands. ${ }^{16}$ The Al-O(naphthoxy) (1.781(2) $\left.\AA\right)$, Al-N(pyridine) $(2.023(2) \AA)$, and Al-C(methyl) (1.943(3)-1.968(4) $\AA$ ) bond distances are in the normal range found for the abovementioned complexes (1.772(2)-1.861(3), 2.027(3) and $1.951(2)-1.979(3) \AA)^{16}$

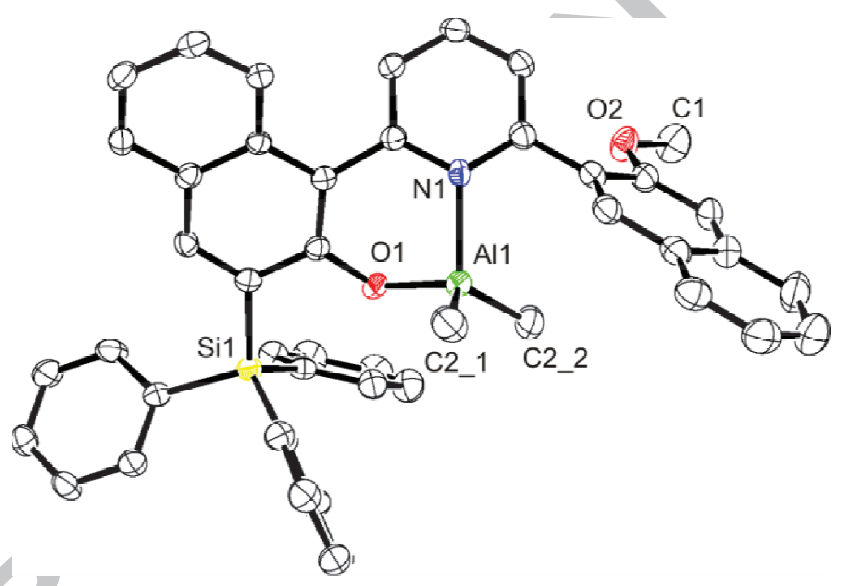

Figure 6. Solid-state molecular structure of $3 \mathbf{c}^{\cdot} \mathrm{C}_{4} \mathrm{H}_{8} \mathrm{O}$ (thermal ellipsoids drawn at $50 \%$ probability; all solvent molecules and hydrogen atoms are omitted for clarity). Selected bond distances $(\AA)$ and angles $(\mathrm{deg}): \mathrm{Al}(1)-\mathrm{O}(1), 1.781(2) ; \mathrm{Al}(1)-\mathrm{N}(1), 2.023(2) ; \mathrm{Al}(1)-\mathrm{C}\left(2 \_1\right)$, 1.968(4); $\quad \mathrm{Al}(1)-\mathrm{C}\left(2 \_2\right), \quad 1.943(3) ; \quad \mathrm{O}(1)-\mathrm{Al}(1)-\mathrm{N}(1), \quad 92.13(9) ; \quad \mathrm{O}(1)-\mathrm{Al}(1)-\mathrm{C}\left(2 \_1\right)$, 111.78(12); $\mathrm{O}(1)-\mathrm{Al}(1)-\mathrm{C}\left(2 \_2\right), \quad 106.12(13), \mathrm{N}(1)-\mathrm{Al}(1)-\mathrm{C}\left(2 \_1\right), \quad 110.30(12) ; \mathrm{N}(1)-\mathrm{Al}(1)-$ $\mathrm{C}\left(2 \_2\right), 112.21(12)$. 
Recrystallization of $\mathbf{3} \mathbf{e}^{\prime}$ from a solution in a toluene/hexanes mixture unexpectedly resulted in isolation of crystals of product 3e", arising from adventitious hydrolysis of the parent monomethyl complex. The molecular structure of $\mathbf{3 e}$ " is depicted in Figure 7. In the oxo-bridged structure of this molecule, each of the two tetrahedral aluminum centers is $\kappa^{3}$ coordinated by a tridentate ligand. The $\mathrm{Al}-\mathrm{O}$ and $\mathrm{Al}-\mathrm{N}$ bond lengths in 3e" are comparable to those observed in $\mathbf{3 c}$ and other related complexes of $o-\mathrm{Ph}_{3} \mathrm{Si}$-substituted phenoxy-imino ligands. ${ }^{16}$

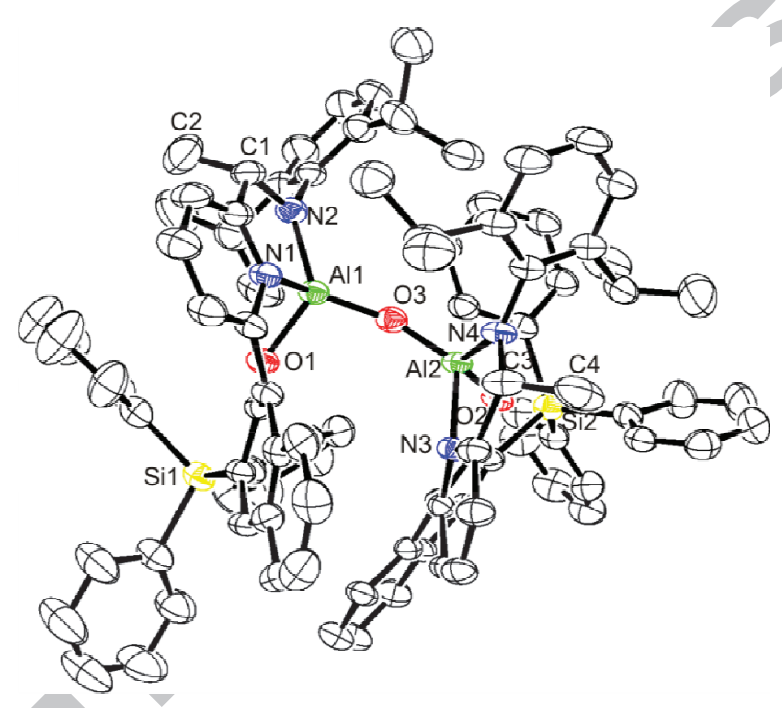

Figure 7. Solid-state molecular structure of $\mathbf{3 e}$ " (thermal ellipsoids drawn at 50\% probability; all hydrogen atoms are omitted for clarity). Selected bond distances (Å) and angles (deg): $\mathrm{Al}(1)-\mathrm{O}(1), 1.7794(15) ; \mathrm{Al}(1)-\mathrm{N}(1), 1.9318(17) ; \mathrm{Al}(1)-\mathrm{N}(2), 1.817(2) ; \mathrm{N}(2)-\mathrm{C}(1), 1.473(3) ;$ $\mathrm{Al}(1)-\mathrm{O}(3), 1.690(2) ; \mathrm{N}(1)-\mathrm{Al}(1)-\mathrm{N}(2), 86.52(8) ; \mathrm{O}(1)-\mathrm{Al}(1)-\mathrm{N}(1), 89.15(7) ; \mathrm{Al}(1)-\mathrm{N}(2)-$ $\mathrm{C}(1), 115.64(14) ; \mathrm{N}(2)-\mathrm{C}(1)-\mathrm{C}(2), 112.6(2) ; \mathrm{O}(1)-\mathrm{Al}(1)-\mathrm{N}(2), 124.66(8), \mathrm{Al}(1)-\mathrm{O}(3)-\mathrm{Al}(2)$, 154.80(9).

Studies on Ring-Opening Polymerization of rac-Lactide (rac-LA) and racButyrolactone (rac-BBL). The new zinc, aluminum and group 3 metals complexes have 
potentially active nucleophilic groups (i.e., alkyl and amido) and their performances as initiators of the ROP of racemic lactide and $\beta$-butyrolactone were assessed. Representative results are summarized in Tables 1 and 2 .

(insert Table 1 here)

Zinc-based Initiators. Not surprisingly in light of the poor nucleophilicity of the ethyl group, zinc ethyl complexes 1a, $1 \mathbf{c}$ and $\mathbf{1 d}$ proved to be quite poor initiators in the ROP of rac-LA. The polymerization did not take place at room temperature and substantial heating $\left(60-100{ }^{\circ} \mathrm{C}\right)$ was required to achieve high conversions. Complex 1a containing the $\mathrm{Ph}_{3}$ Si-disubstituted bis(naphthoxy) ligand was not active even under these conditions (Table 1, entries 1 and 2). When combined with isopropanol (5 equiv), 1a appeared to be active at $100{ }^{\circ} \mathrm{C}$, slowly converting 100 and 1,000 equiv of lactide (entries 3 and 4, respectively). The atactic PLAs formed under those conditions had unimodal, although broadened molecular distributions with the experimental number-average molecular weights being close to the calculated ones (based on the converted monomer-to-alcohol ratio).

Complexes with the less bulky ligands $\mathbf{1 c}$ and $\mathbf{1 d}$ exhibited higher activity than $\mathbf{1 a}$ and enabled the conversion of 100 equiv of rac-lactide within a few minutes at $80{ }^{\circ} \mathrm{C}$ in toluene or at $60^{\circ} \mathrm{C}$ in $\mathrm{THF}$ solution, even without addition of isopropanol (entries 6, 7 and 5, respectively). The resulting slightly heterotactic-enriched PLAs $\left(P_{\mathrm{r}}=0.65-0.75\right)$ have relatively broad molecular distributions $\left(\bigoplus_{\mathrm{M}}=1.5-2.1\right)$.

As expected, the more nucleophilic amide-zinc complexes $\mathbf{2 c}, \mathbf{2 d}$ and $\mathbf{2 e}$ proved to be active at room temperature, enabling the conversion of 100-2,000 equiv of rac-LA within relatively short periods of time (entries $8-12,15-17$ ). The PLAs obtained with $\mathbf{2 c}$ and $\mathbf{2 d}$ under these conditions had also unimodal, yet rather broad molecular weight distributions $\left(\bigoplus_{\mathrm{M}}\right.$ $=1.3-2.0$ ), which argues for their unoptimal initiation efficiency and/or propensity to promote side-reactions such as transesterification. Remarkably, 2e even without $i \mathrm{PrOH}$ (entries 16 and 17) afforded PLAs with rather narrow polydispersities $\left(\bigoplus_{M}=1.11\right)$ and good agreement 
between the experimental and calculated molecular weights. The presence of isopropanol turned out to be detrimental for the activities of these systems. For instance, the combinations of $2 \mathbf{c}$ or $2 \mathbf{e}$ with $\underline{i} \mathrm{PrOH}$ (one equiv) were completely inactive at room temperature (entries 13, 18 and 19). Actually, an NMR monitoring of the reaction of $\mathbf{2 c}$ with one equiv of isopropanol in toluene- $d_{8}$ at room temperature indicated decomposition of the complex with release of protio c. Homo-decoupled ${ }^{1} \mathrm{H}$ NMR spectroscopy showed that the PLAs obtained with systems 2c, 2d and 2e all had a slightly heterotactic-enriched microstructures $\left(P_{\mathrm{r}}=\right.$ $0.65-0.76)$.

The performance of $\mathbf{2 c}$ and $\mathbf{2 e}$, the most active complexes towards $r a c$-LA, were next assessed in the ROP of rac-BBL. Polymerization occurred only upon heating at $60-80{ }^{\circ} \mathrm{C}$ and complete conversions were reached after longer time periods (Table 2, entries 2 and 3). Despite the absence of co-initiator / chain-transfer agent $(i \mathrm{PrOH})$, the initiation with these systems appeared remarkably efficient and PHBs featuring narrow molecular weight distributions were isolated $\left(\oslash_{\mathrm{M}}=1.07-1.23\right)$. Yet, the experimental number average molecular weights were not systematically close to the calculated ones. Also, polymerizations with $\mathbf{2 c}$ and $\mathbf{2 e}$ were found to be essentially nonstereoselective.

(insert Table 2 here)

Aluminum-based Initiators. ROP of rac-LA with dimethyl-aluminum $3 \mathbf{c}$ and monomethyl-aluminum $3 \mathbf{e}^{\prime}$ proceeded at $100{ }^{\circ} \mathrm{C}$ in toluene (Table 1, entries 20-23). In general, a good control over the polymerization was achieved with both systems in the presence of isopropanol, as evidenced by the relatively narrow molecular weight distribution of the resulting polymers $\left(\bigoplus_{\mathrm{M}}=1.17-1.37\right)$ and the good agreement between observed and theoretical molecular weights calculated on the assumption of the growth on one macromolecular chain per metal center. The homo-decoupled ${ }^{1} \mathrm{H}$ NMR experiments conducted on the PLAs samples produced with these aluminum compounds indicated that all 
of them are atactic. On the other hand, complexes $\mathbf{3 c}$ and $\mathbf{3 e}$ ' were found completely inactive towards rac-BBL (Table 2, entries 7-9), which is not unsurprising for aluminum complexes. ${ }^{1}$

Group 3 Metal-based Initiators. The group 3 diamido $4 \mathbf{e}$ and monoamido $\mathbf{5 f}$ and $\mathbf{6 f}$ were found very active toward the ROP of $r a c$-LA at room temperature (Table 1, entries 24-28, 30-35); nearly quantitative conversions of the monomer were achieved within a few minutes (for $4 \mathbf{e}$, TOF up to $1840 \mathrm{~mol}(\mathrm{LA}) \cdot \mathrm{mol}(\mathrm{Y})^{-1} \cdot \mathrm{h}^{-1}$ at $25^{\circ} \mathrm{C}$ ). Without the addition of isopropanol, yttrium compound $\mathbf{4 e}$ gave PLAs with broad molecular weight distributions $\left(\bigoplus_{\mathrm{M}}\right.$ $=2.1$, entries 24-26) and number-average molecular weight values generally twice larger with respect to those calculated from the monomer-to-yttrium ratio. The reactions proceeded even faster in the presence of isopropanol (compare entries 24/27 and 26/28) and all the PLAs formed under those conditions had unimodal narrow molecular distributions $\left(\bigoplus_{\mathrm{M}}=\right.$ 1.21-1.35) and experimental number-average molecular weights $\left(M_{\mathrm{n}}\right)$ quite close to the calculated values (entries 27 and 28), indicating a more controlled behavior.

Within the $\mathbf{f}$ series, the activity of complexes clearly follows the order of ionic radii of metals $\operatorname{La}(\mathbf{6 f})>Y(\mathbf{5 f})>\operatorname{Sc}(\mathbf{4 f})$. Thus, for scandium complex $\mathbf{4 f}$, a substantial heating was required to achieve a good conversion (entry 29). Such trend was already observed for a similar series of group 3 metal amino-alkoxy-bis(phenolate) complexes and was explained on account of a more sterically hindered metal center. ${ }^{17}$ These lanthanide systems provided relatively broad molecular weight distributions $\left(\nexists_{\mathrm{M}}=1.4-2.0\right)$, which do not improve much if isopropanol is used as chain-transfer agent (compare entries 30/33 and 34/35). Homodecoupled ${ }^{1} \mathrm{H}$ NMR spectroscopy showed that the PLAs formed with these systems have heterotactic-enriched microstructures with the probability of racemic linkage ranging from $0.78-0.80$ for $4 \mathbf{e}$ to $0.57-0.69$ for $\mathbf{4 - 6 f}$.

In line with previous reports, ${ }^{5 b, 17}$ the activities of complexes $\mathbf{4 e}$ and $\mathbf{4 - 6 \mathbf { f }}$ in the ROP of rac-BBL were found inferior to those of rac-LA (Table 2, entries 10-14). For instance, polymerization reactions with $\mathbf{5 f}$ and $\mathbf{6 f}$ required longer periods of time, while with $\mathbf{4 f}$ they 
did not take place at all even at $60{ }^{\circ} \mathrm{C}$. For the most active 4e, the TOF was up to 900 $\operatorname{mol}(\mathrm{BBL}) \cdot \mathrm{mol}(\mathrm{Y})^{-1} \cdot \mathrm{h}^{-1}$ at $25{ }^{\circ} \mathrm{C}$. The resulting PHBs had molecular weights distributions that were unimodal, although somewhat large $\left(\bigoplus_{\mathrm{M}}=1.5-1.9\right)$. None of these complexes proved to be stereoselective, giving mostly atactic PHB polymers $\left(P_{\mathrm{r}}=0.42-0.66\right)$.

\section{Conclusions}

Several new series of bulky $\mathrm{Ph}_{3}$ Si-substituted tridentate naphthol-pyridine proligands have been conveniently prepared and straightforwardly installed onto $\mathrm{Zn}, \mathrm{Al}$ and group 3 metals ( $\mathrm{Sc}, \mathrm{Y}$ and $\mathrm{La}$ ) as alkyl and amido complexes. These monomeric and monometallic complexes all adopt $C_{1}$-symmetry both in the solid state and in solution (benzene, toluene or THF).

Studies in the ROP of rac-LA and rac-BBL indicated that some of these systems exhibit significant activity, good molecular weight control and narrow molecular weight distributions. On the other hand, modest degrees of stereocontrol were achieved with these systems. The performances of the complexes obtained in this study compare well with that of their corresponding imino-phenoxide and related analogues. ${ }^{5 b, 15,16,18}$

\section{Experimental Section}

General Considerations. All manipulations were performed under a purified argon atmosphere using standard Schlenk techniques or in a glovebox $\left(<1 \mathrm{ppm}_{2},<5 \mathrm{ppm} \mathrm{H}_{2} \mathrm{O}\right)$. Solvents were distilled from $\mathrm{Na} /$ benzophenone $\left(\mathrm{THF}, \mathrm{Et}_{2} \mathrm{O}\right.$ ) or $\mathrm{Na} / \mathrm{K}$ alloy (toluene, hexane and pentane) under argon, degassed thoroughly and stored under argon prior to use. Deuterated solvents were stored over Na/K alloy (benzene- $d_{6}$, toluene- $d_{8}$, THF- $d_{8} ;>99.5 \% \mathrm{D}$, Eurisotop) and vacuum-transferred just before use. $\mathrm{CDCl}_{3}$ was dried over a mixture of 3 and $4 \AA$ molecular sieves. Precursors $\mathrm{Ln}\left[\mathrm{N}\left(\mathrm{SiHMe}_{2}\right)_{2}\right]_{3}(\mathrm{THF}) \quad(\mathrm{Ln}=\mathrm{Sc}, \mathrm{Y}, \mathrm{La})^{19}$ and $\mathrm{Zn}\left[\mathrm{N}\left(\mathrm{SiMe}_{3}\right)\right]_{2}{ }^{20}$ were prepared as described in the literature. Other starting materials were 
purchased from Acros, Strem, Alfa and Aldrich and used as received. Racemic lactide (racLA) and racemic $\beta$-butyrolactone (rac-BBL) were received from Aldrich and TCI, respectively. Purification of $r a c$-LA required a three-step procedure involving first a recrystallization from a hot, concentrated $i \mathrm{PrOH}$ solution $\left(80^{\circ} \mathrm{C}\right)$, followed by two subsequent recrystallizations in hot toluene $\left(100{ }^{\circ} \mathrm{C}\right)$. Rac-BBL was freshly distilled from $\mathrm{CaH}_{2}$ under nitrogen and degassed thoroughly by freeze-thaw-vacuum cycles prior to use. After purification, $r a c$-LA and $r a c$-BBL were stored at $-30{ }^{\circ} \mathrm{C}$ in the glove-box.

Instrumentation and Measurements. NMR spectra of complexes were recorded on Bruker Avance DRX 400 and AM-500 spectrometers in Teflon-valved NMR tubes at 25 ${ }^{\circ} \mathrm{C}$ unless otherwise indicated. ${ }^{1} \mathrm{H}$ and ${ }^{13} \mathrm{C}$ NMR chemical shifts are reported in ppm $v s$. $\mathrm{SiMe}_{4}$ and were determined by reference to the residual solvent peaks. Assignment of resonances for organometallic complexes was made from $2 \mathrm{D}{ }^{1} \mathrm{H}-{ }^{13} \mathrm{C}$ HMQC and HMBC NMR experiments. ${ }^{29} \mathrm{Si}$ chemical shifts were determined with respect to the external reference $\left(\mathrm{Me}_{4} \mathrm{Si}\right)$.

Elemental analyses $(\mathrm{C}, \mathrm{H}, \mathrm{N})$ were performed on recrystallized samples that were thoroughly dried under vacuum, using a Flash EA1112 CHNS Thermo Electron apparatus and are the average of two independent determinations.

Size exclusion chromatography (SEC) analyses of PLAs and PHBs were performed in THF $\left(1,0 \mathrm{~mL} \cdot \mathrm{min}^{-1}\right)$ at $20{ }^{\circ} \mathrm{C}$ using a Polymer Laboratories PL-GPC 50 plus apparatus equipped with two ResiPore $300 \times 7.5 \mathrm{~mm}$ columns, and RI and Dual angle LS (PL-LS 45/90) detectors. The number-average molecular masses $\left(M_{\mathrm{n}}\right)$ and polydispersity index $\left(M_{\mathrm{w}} / M_{\mathrm{n}}\right)$ of the polymers were calculated with reference to a universal calibration $v s$. polystyrene standards. Reported experimental SEC molar mass values $\left(M_{\mathrm{n}}, \mathrm{SEC}\right)$ for PLA samples were corrected by a factor of 0.58 as previously established; ${ }^{21}$ those of PHBs are uncorrected. Unless otherwise stated, the SEC traces of the polymers all exhibited a unimodal, and usually symmetrical, peak. 


\section{(3-(Methoxymethoxy)-4-(4,4,5,5-tetramethyl-1,3,2-dioxaborolan-2-}

yl)naphthalen-2-yl)triphenylsilane. To a solution of [3-(methoxymethoxy)-2naphthyl)](triphenylsilane $)^{3}(5.00 \mathrm{~g}, 11.19 \mathrm{mmol})$ in THF (100 mL) was added TMEDA (1.67 $\mathrm{mL}, 11.21 \mathrm{mmol})$ followed by addition of $\mathrm{sec}-\mathrm{BuLi}(9.12 \mathrm{~mL}$ of a $1.3 \mathrm{M}$ solution in hexane/cyclohexane, $11.86 \mathrm{mmol}$ ) at $-78{ }^{\circ} \mathrm{C}$. The reaction mixture was stirred at room temperature overnight. Then, 2-isopropoxy-4,4,5,5-tetramethyl-1,3,2-dioxaborolane (3.65 $\mathrm{mL}, 17.90 \mathrm{mmol}$ ) was added via syringe at $-78{ }^{\circ} \mathrm{C}$. After $30 \mathrm{~min}$ at $-78{ }^{\circ} \mathrm{C}$, the flask was removed from the cooling bath and allowed to warm to room temperature while stirring; the reaction mixture was stirred at $70^{\circ} \mathrm{C}$ overnight. The reaction was quenched with saturated aqueous ammonium chloride and extracted with $\mathrm{CH}_{2} \mathrm{Cl}_{2}(3 \times 50 \mathrm{~mL})$. The combined organic layers were dried over magnesium sulfate and evaporated to yield a yellowish solid. The product was purified by passing through a short silica column using $\mathrm{CH}_{2} \mathrm{Cl}_{2}$ as eluent, to afford the product as an off-white solid $(5.45 \mathrm{~g}, 85 \%) .{ }^{1} \mathrm{H} \mathrm{NMR}\left(500 \mathrm{MHz}, \mathrm{CDCl}_{3}, 298 \mathrm{~K}\right): \delta$ $8.00\left(\mathrm{~d},{ }^{3} J_{H-H}=8.4,1 \mathrm{H}\right.$, aryl-CH$), 7.76(\mathrm{~s}, 1 \mathrm{H}, \operatorname{aryl}-\mathrm{CH}), 7.61\left(\mathrm{~d},{ }^{3} J_{H-H}=7.6,6 \mathrm{H}\right.$, aryl-CH$)$, 7.47-7.44 (m, 1H, aryl-CH), 7.41-7.38 (m, 4H, aryl-CH), 7.36-7.33 (m, 6H, aryl-CH), 7.31-7.28 (m, $1 \mathrm{H}$, aryl-CH), $4.67\left(\mathrm{~s}, 2 \mathrm{H}, \mathrm{CH}_{2} \mathrm{OCH}_{3}\right), 2.89\left(\mathrm{~s}, 3 \mathrm{H}, \mathrm{CH}_{2} \mathrm{OCH}_{3}\right), 1.48(\mathrm{~s}, 12 \mathrm{H}$, $\left.\operatorname{BOC}\left(\mathrm{CH}_{3}\right)_{2}\right) .{ }^{13} \mathrm{C} \mathrm{NMR}\left(125 \mathrm{MHz}, \mathrm{CDCl}_{3}, 298 \mathrm{~K}\right): \delta 162.2$ (aryl- $\left.\mathrm{Cq}\right), 142.3(\operatorname{aryl}-\mathrm{CH}), 139.0$ $(\operatorname{aryl}-C \mathrm{q}), 136.4(\operatorname{aryl}-C H), 136.3(\operatorname{aryl}-C H), 135.2(\operatorname{aryl}-C \mathrm{q}), 129.4(\operatorname{aryl}-C \mathrm{q}), 129.2$ (aryl$C H), 128.8$ (aryl- $C H), 128.1$ (aryl- $C H), 127.6(\operatorname{aryl}-C H), 127.0$ (aryl- $C H), 126.9$ (aryl-Cq), 126.6 (aryl- $\mathrm{CH}), 123.8$ (aryl- $\mathrm{CH}), 96.0\left(\mathrm{CH}_{2} \mathrm{OCH}_{3}\right), 84.3\left(\left(\mathrm{BOC}\left(\mathrm{CH}_{3}\right)_{2}\right)\right), 55.4\left(\mathrm{CH}_{2} \mathrm{OCH}_{3}\right)$, 25.9 $\left(\mathrm{BOC}\left(\mathrm{CH}_{3}\right)_{2}\right)$. Anal. Calcd for $\mathrm{C}_{36} \mathrm{H}_{37} \mathrm{BO}_{4} \mathrm{Si}: \mathrm{C}, 75.52 ; \mathrm{H}, 6.51$. Found: $\mathrm{C}, 75.48 ; \mathrm{H}$, 6.54 .

2-Bromo-6-(2-(methoxymethoxy)-3-(triphenylsilyl)naphthalen-1-yl)pyridine. An oven-dried $250 \mathrm{~mL}$ Schlenk flask, equipped with a stirring bar and a Teflon valve, was charged with 2,6-dimethylpyridine (2.47 g, $10.47 \mathrm{mmol})$, (3-(methoxymethoxy)-4-(4,4,5,5tetramethyl-1,3,2-dioxaborolan-2-yl)naphthalen-2-yl)triphenylsilane (5.45 g, $9.52 \mathrm{mmol})$, 
$\mathrm{Pd}\left(\mathrm{PPh}_{3}\right)_{4}(0.55 \mathrm{~g}, 0.47 \mathrm{mmol})$ and $\mathrm{K}_{3} \mathrm{PO}_{4}(4.05 \mathrm{~g}, 19.11 \mathrm{mmol})$ under argon. Then, dry toluene $(100 \mathrm{~mL})$ was added via syringe. The reaction mixture was stirred at room temperature for $30 \mathrm{~min}$, during this time the bright yellow color faded to pale yellow (with insoluble white $\mathrm{K}_{3} \mathrm{PO}_{4}$ ). The flask was placed in an oil bath at $115{ }^{\circ} \mathrm{C}$ with stirring for 3 days. Then, the reaction mixture was cooled to room temperature and the suspension was filtered through celite with the aid of $\mathrm{Et}_{2} \mathrm{O}$. Volatiles were removed under vacuum and the resulting residue was purified by recrystallization using an $\mathrm{Et}_{2} \mathrm{O} / \mathrm{CH}_{2} \mathrm{Cl}_{2}$ mixture (1:1) to give a solid (3.00 g, 52\%). ${ }^{1} \mathrm{H}$ NMR (500 MHz, $\left.\mathrm{CDCl}_{3}, 298 \mathrm{~K}\right): \delta 7.88$ (s, 1H, aryl-CH), 7.69-7.67 (m, $2 \mathrm{H}$, aryl-CH), $7.64\left(\mathrm{~d},{ }^{3} J_{H-H}=7.4,7 \mathrm{H}\right.$, aryl- $\left.\mathrm{CH}\right), 7.53-7.47(\mathrm{~m}, 3 \mathrm{H}$, aryl-CH$), 7.43-7.42(\mathrm{~m}$, $3 \mathrm{H}$, aryl-CH), 7.39-7.37 (m, 1H, aryl-CH), 3.91 (s, 2H, $\left.\mathrm{CH}_{2} \mathrm{OCH}_{3}\right), 2.62\left(\mathrm{~s}, 3 \mathrm{H}, \mathrm{CH}_{2} \mathrm{OCH}_{3}\right)$. ${ }^{13} \mathrm{C}$ NMR (125 MHz, $\mathrm{CDCl}_{3}, 298 \mathrm{~K}$ ): $\delta 157.9$ (aryl-Cq), 157.2 (aryl-Cq), 141.6 (aryl-CH), 141.4 (aryl-Cq), 138.6 (aryl- $C H$ ), 136.5 (aryl- $C H$ ), 134.8 (aryl- $C q), 134.6$ (aryl- $C q), 130.2$ (aryl-Cq), 129.5 (aryl-CH), 128.9 (aryl- $C \mathrm{q}), 128.5$ (aryl- $\mathrm{CH}), 127.8$ (aryl-CH), 127.7 (arylCH), 126.7 (aryl-Cq), 126.6 (aryl- $C H$ ), 125.9 (aryl-CH), 124.9 (aryl-CH), 124.8 (aryl- $C H$ ), $99.4\left(\mathrm{CH}_{2} \mathrm{OCH}_{3}\right), 56.0\left(\mathrm{CH}_{2} \mathrm{OCH}_{3}\right)$. Anal. Calcd for $\mathrm{C}_{35} \mathrm{H}_{28} \mathrm{BrNO}_{2} \mathrm{Si}: \mathrm{C}, 69.76 ; \mathrm{H}, 4.68 ; \mathrm{N}$, 2.32. Found: $\mathrm{C}, 69.72 ; \mathrm{H}, 4.56 ; \mathrm{N}, 2.30$.

6-(2-(Methoxymethoxy)-3-(triphenylsilyl)naphthalen-1-yl)picolinaldehyde. (3(Methoxymethoxy)-4-(4,4,5,5-tetramethyl-1,3,2-dioxaborolan-2-yl)naphthalen-2yl)triphenylsilane $(5.00 \mathrm{~g}, 8.7 \mathrm{mmol})$ and $\mathrm{Na}_{2} \mathrm{CO}_{3}(1.91 \mathrm{~g}, 18.1 \mathrm{mmol})$ were dissolved in a degassed $\mathrm{H}_{2} \mathrm{O} / \mathrm{MeOH}$ mixture $(4: 1,60 \mathrm{~mL})$. The resulting solution was added via cannula to a solution of 6-bromopicolinaldehyde (1.35 g, $7.2 \mathrm{mmol})$ and $\mathrm{Pd}\left(\mathrm{PPh}_{3}\right)_{4}(416 \mathrm{mg}, 0.36 \mathrm{mmol})$ in degassed toluene $(50 \mathrm{~mL})$. The biphasic mixture was heated to $90{ }^{\circ} \mathrm{C}$ for $48 \mathrm{~h}$ under vigorous stirring. After cooling to room temperature, the organic phase was separated and washed with $\mathrm{Et}_{2} \mathrm{O}(3 \times 25 \mathrm{~mL})$. The combined organic extracts were washed with $\mathrm{H}_{2} \mathrm{O}(3 \times$ $25 \mathrm{~mL})$ and brine $(1 \times 20 \mathrm{~mL})$, and dried over $\mathrm{Na}_{2} \mathrm{SO}_{4}$. Volatiles were removed under vacuum, and the resulting brown oil was chromatographed on silica using $\mathrm{CH}_{2} \mathrm{Cl}_{2}$ as eluent. 


\section{ACCEPTED MANUSCRIPT}

The early fractions containing (3-(methoxymethoxy)-4-(4,4,5,5-tetramethyl-1,3,2dioxaborolan-2-yl)naphthalen-2-yl)triphenylsilane and 6-bromopicolinaldehyde were separated. The remaining fractions were combined and volatiles were removed under vacuum to provide 6-(2-(methoxymethoxy)-3-(triphenylsilyl)naphthalen-1-yl)picolinaldehyde as a yellow solid (2.50 g, 63\%). ${ }^{1} \mathrm{H}$ NMR (500 MHz, $\left.\mathrm{CDCl}_{3}, 298 \mathrm{~K}\right): \delta 10.19$ (s, 1H, CHO), 8.04-8.03 (m, 1H, aryl-CH), $7.96(\mathrm{~s}, 1 \mathrm{H}$, aryl- $\mathrm{CH}), 7.79-7.75(\mathrm{~m}, 2 \mathrm{H}$, aryl-CH), 7.70-7.68 (m, 6H, aryl-CH), 7.49-7.40 (m, 13H, aryl-CH), 3.89 (br s, $\left.2 \mathrm{H}, \mathrm{CH}_{2} \mathrm{OCH}_{3}\right), 2.55(\mathrm{~s}, 3 \mathrm{H}$, $\left.\mathrm{CH}_{2} \mathrm{OCH}_{3}\right) .{ }^{13} \mathrm{C}$ NMR $\left(125 \mathrm{MHz}, \mathrm{CDCl}_{3}, 298 \mathrm{~K}\right): \delta 193.7$ (CHO), 157.7 (aryl-Cq), 157.5 (aryl-Cq), 152.6 (aryl-Cq), 141.7 (aryl-CH), 137.3 (aryl-CH), 136.5 (aryl-CH), 134.7 (arylCq), 134.6 (aryl-Cq), 131.6 (aryl-CH), 130.4 (aryl-Cq), 129.6 (aryl-CH), 129.1 (aryl-Cq), 128.7 (aryl- $C H), 127.9(\operatorname{aryl}-C H), 127.8(\operatorname{aryl}-C H), 127.1(\operatorname{aryl}-C q), 125.0(\operatorname{aryl}-C H), 124.6$ (aryl- $\mathrm{CH}), \quad 120.0 \quad(\operatorname{aryl}-\mathrm{CH}), \quad 99.5 \quad\left(\mathrm{CH}_{2} \mathrm{OCH}_{3}\right), 55.9\left(\mathrm{CH}_{2} \mathrm{OCH}_{3}\right)$. Anal. Calcd for $\mathrm{C}_{36} \mathrm{H}_{29} \mathrm{NO}_{3} \mathrm{Si}: \mathrm{C}, 78.37 ; \mathrm{H}, 5.30 ; \mathrm{N}, 2.54$. Found: C, 78.42; H, 5.35; N, 2.60.

6-(2-Hydroxy-3-(triphenylsilyl)naphthalen-1-yl)picolinaldehyde.

(Methoxymethoxy)-3-(triphenylsilyl)naphthalen-1-yl)picolinaldehyde (2.50 g, $4.53 \mathrm{mmol})$ was dissolved in a mixture of concentrated $\mathrm{HCl}(20 \mathrm{~mL}), \mathrm{CHCl}_{3}(30 \mathrm{~mL})$, and $\mathrm{EtOH}(40 \mathrm{~mL})$, and the solution was refluxed for $4 \mathrm{~h}$. The reaction mixture was cooled to $0{ }^{\circ} \mathrm{C}$ and then carefully diluted with a concentrated solution of $\mathrm{NaOH}(50 \mathrm{~mL})$. Then, a concentrated solution of $\mathrm{NH}_{4} \mathrm{Cl}$ was added to adjust the $\mathrm{pH}$ value to $7-8$. The product was extracted with $\mathrm{CH}_{2} \mathrm{Cl}_{2}(3 \times 20 \mathrm{~mL})$, and the combined organic extracts were dried over $\mathrm{MgSO}_{4}$ and evaporated to afford the desired compound as a yellow solid $(1.20 \mathrm{~g}, 52 \%) . \quad{ }^{1} \mathrm{H}$ NMR (400 $\left.\mathrm{MHz}, \mathrm{CDCl}_{3}, 298 \mathrm{~K}\right): \delta 12.01(\mathrm{~s}, 1 \mathrm{H}, \mathrm{OH}), 10.09(\mathrm{~s}, 1 \mathrm{H}, \mathrm{CHO}), 8.28\left(\mathrm{~d},{ }^{3} J_{H-H}=8.6 \mathrm{~Hz}, 1 \mathrm{H}\right.$, aryl-CH), $8.14\left(\mathrm{t},{ }^{3} J_{H-H}=8.1,2 \mathrm{H}, \operatorname{aryl}-\mathrm{C} H\right), 8.00-7.92(\mathrm{~m}, 5 \mathrm{H}, \operatorname{aryl}-\mathrm{CH}), 7.85\left(\mathrm{~d},{ }^{3} J_{H-H}=6.5\right.$, $5 \mathrm{H}$, aryl-CH), $7.76\left(\mathrm{~d},{ }^{3} J_{H-H}=7.9,1 \mathrm{H}, \operatorname{aryl}-\mathrm{C} H\right), 7.73\left(\mathrm{~d},{ }^{3} J_{H-H}=8.1,1 \mathrm{H}, \operatorname{aryl}-\mathrm{CH}\right), 7.65(\mathrm{~d}$, ${ }^{3} J_{H-H}=7.4,1 \mathrm{H}$, aryl-CH $), 7.55-7.45(\mathrm{~m}, 5 \mathrm{H}$, aryl-CH), 7.39-7.32 (m, 2H, aryl-CH). 
Proligand a. A Schlenk flask was charged with a 1,1'-(pyridine-2,6-diyl)bis(3(triphenylsilyl)naphthalen-2-ol) ${ }^{3}(1.00 \mathrm{~g}, 1.13 \mathrm{mmol})$ and $\mathrm{PhCH}_{2} \mathrm{~K}(0.148 \mathrm{~g}, 1.13 \mathrm{mmol})$, and THF (ca. $10 \mathrm{~mL}$ ) was vacuum transferred in at $-78{ }^{\circ} \mathrm{C}$. The reaction mixture was gently warmed to room temperature and stirred for $2 \mathrm{~h}$ at $60{ }^{\circ} \mathrm{C}$. To this mixture, MeI $(77.8 \mu \mathrm{L}, 1.25$ mmol) was added dropwise at $-78{ }^{\circ} \mathrm{C}$. The reaction mixture was stirred for $24 \mathrm{~h}$ at $60{ }^{\circ} \mathrm{C}$, cooled to room temperature, diluted with water $(50 \mathrm{~mL})$, and extracted with $\mathrm{CH}_{2} \mathrm{Cl}_{2}(3 \times 20$ $\mathrm{mL}$ ). The combined organic extracts were dried over $\mathrm{MgSO}_{4}$ and evaporated to dryness. The crude material contained $c a .50 \%$ of the desired product, 1-(6-(2-methoxy-3(triphenylsilyl)naphthalen-1-yl)pyridin-2-yl)-3-(triphenylsilyl)naphthalen-2-ol, as judged by ${ }^{1} \mathrm{H}$ NMR spectroscopy. This crude material was purified by column chromatography (silica, heptane/EtOAc (9:1), $\left.\mathrm{R}_{f}=0.10\right)$ and recrystallized from an heptane/EtOAc $(9: 1)$ mixture to give, after drying under vacuum, an analytically pure yellow microcrystalline material $(0.50$ g, 49\%). ${ }^{1} \mathrm{H}$ NMR $\left(400 \mathrm{MHz}, \mathrm{CDCl}_{3}, 298 \mathrm{~K}\right): \delta 12.87$ (br s, $\left.1 \mathrm{H}, \mathrm{OH}\right), 8.22\left(\mathrm{~d},{ }^{3} J_{H-H}=8.6\right.$, 1H, aryl-CH), 7.91-7.87 (m, 2H, aryl-CH), $7.78(\mathrm{~s}, 1 \mathrm{H}$, aryl- $\mathrm{CH}), 7.67(\mathrm{~s}, 1 \mathrm{H}$, aryl-CH), 7.64-7.60 (m, 2H, aryl-CH), 7.56-7.51 (m, 12H, aryl- $\mathrm{CH}), 7.44-7.39(\mathrm{~m}, 2 \mathrm{H}$, aryl- $\mathrm{CH})$, 7.32-7.16 (m, 22H, aryl-CH), $2.29\left(\mathrm{~s}, 3 \mathrm{H}, \mathrm{OCH}_{3}\right) .{ }^{13} \mathrm{C} \mathrm{NMR}\left(100 \mathrm{MHz}, \mathrm{CDCl}_{3}, 298 \mathrm{~K}\right): \delta$ 160.5 (aryl-Cq), 160.4 (aryl-Cq), 156.9 (aryl-Cq), 154.1 (aryl-Cq), 142.8 (aryl-CH), 141.1 (aryl- $\mathrm{CH}), 137.2(\operatorname{aryl}-\mathrm{CH}), 136.6(\operatorname{aryl}-\mathrm{CH}), 136.4$ (aryl- $\mathrm{CH}), 134.8$ (aryl-Cq), 134.7 (aryl$C \mathrm{q}), 134.6$ (aryl-Cq), 133.2 (aryl-Cq), 130.2 (aryl-Cq), 129.4 (aryl-CH), 129.3 (aryl-CH), 129.2 (aryl- $C H), 129.1$ (aryl- $C \mathrm{q}), 128.8$ (aryl- $C \mathrm{q}), 128.7$ (aryl- $\mathrm{CH}), 127.8$ (aryl- $\mathrm{CH}), 127.7$ (aryl-CH), $127.6(\operatorname{aryl}-C H), 125.9$ (aryl-Cq), 125.2 (aryl-Cq), 124.7 (aryl-CH), 124.6 (aryl$C H), 124.5$ (aryl- $C H), 124.4$ (aryl- $C H), 123.6$ (aryl-CH), 122.8 (aryl- $C H), 113.0$ (aryl-Cq), $60.4\left(\mathrm{CH}_{3}\right)$. Anal. Calcd for $\mathrm{C}_{62} \mathrm{H}_{47} \mathrm{NO}_{2} \mathrm{Si}_{2}: \mathrm{C}, 83.28 ; \mathrm{H}, 5.30 ; \mathrm{N}, 1.57$. Found: $\mathrm{C}, 83.35 ; \mathrm{H}$, $5.16 ; \mathrm{N}, 1.53$.

Proligand $\mathbf{b}$. Using a procedure similar to that described above for $\mathbf{a}$, proligand $\mathbf{b}$ was obtained 1,1'-(pyridine-2,6-diyl)bis(3-(triphenylsilyl)naphthalen-2-ol) $\quad\left(\begin{array}{lll}1.00 & \mathrm{~g}, & 1.13\end{array}\right.$ 
mmol), $\mathrm{PhCH}_{2} \mathrm{~K}(0.148 \mathrm{~g}, 1.13 \mathrm{mmol}), \mathrm{Bu}_{4} \mathrm{NI}(0.461 \mathrm{~g}, 1.25 \mathrm{mmol})$ and $\mathrm{BnBr}(148.5 \mu \mathrm{L}$, $1.25 \mathrm{mmol})$. The crude material contained $c a .50 \%$ of desired product, 1-(6-(2-(benzyloxy)3-(triphenylsilyl)naphthalen-1-yl)pyridin-2-yl)-3-(triphenylsilyl)naphthalen-2-ol, as judged by ${ }^{1} \mathrm{H}$ NMR spectroscopy. This crude material was purified by column chromatography (silica, heptane/toluene (6:4), $\left.\mathbf{R}_{f}=0.33\right)$. Pure compound $\mathbf{b}$ was recovered as a pale yellow powder (0.50 g, 46\%). ${ }^{1} \mathrm{H}$ NMR (400 MHz, $\left.\mathrm{CDCl}_{3}, 298 \mathrm{~K}\right): \delta 12.94(\mathrm{~s}, 1 \mathrm{H}, \mathrm{OH}), 8.15\left(\mathrm{~d},{ }^{3} J_{H-H}=8.5\right.$, $1 \mathrm{H}$, aryl-CH), $7.84\left(\mathrm{~s}, 1 \mathrm{H}\right.$, aryl-CH), $7.72\left(\mathrm{~d},{ }^{3} J_{H-H}=8.0,1 \mathrm{H}\right.$, aryl- $\left.\mathrm{CH}\right), 7.68(\mathrm{~s}, 1 \mathrm{H}$, aryl-CH$)$, $7.62\left(\mathrm{~d},{ }^{3} J_{H-H}=7.4,1 \mathrm{H}\right.$, aryl-CH$), 7.63-7.52(\mathrm{~m}, 16 \mathrm{H}, \operatorname{aryl}-\mathrm{CH}), 7.41-7.37(\mathrm{~m}, 1 \mathrm{H}$, aryl-CH$)$, 7.32-7.15 (m, 21H, aryl-CH), $6.88\left(\mathrm{t},{ }^{3} J_{H-H}=7.3,1 \mathrm{H}, \mathrm{OCH}_{2} P h\right), 6.78\left(\mathrm{t},{ }^{3} J_{H-H}=7.5,2 \mathrm{H}\right.$, $\left.\mathrm{OCH}_{2} \mathrm{Ph}\right), 6.23\left(\mathrm{~d},{ }^{3} \mathrm{~J}_{\mathrm{H}-\mathrm{H}}=7.3,2 \mathrm{H}, \mathrm{OCH}_{2} \mathrm{Ph}\right), 3.81\left(\mathrm{~s}, 2 \mathrm{H}, \mathrm{OCH}_{2} \mathrm{Ph}\right) .{ }^{13} \mathrm{C} \mathrm{NMR}(100 \mathrm{MHz}$, $\mathrm{CDCl}_{3}, 298 \mathrm{~K}$ ): $\delta 160.4$ (aryl-Cq), 159.4 (aryl-Cq), 156.5 (aryl-Cq), 154.0 (aryl-Cq), 142.8 (aryl-CH), $141.4(\operatorname{aryl}-\mathrm{CH}), 137.5$ (aryl-Cq), 137.1 (aryl- $C H), 136.6(\operatorname{aryl}-\mathrm{CH}), 136.5$ (arylCH), 134.8 (aryl-Cq), 134.7 (aryl-Cq), 134.6 (aryl-Cq), 133.2 (aryl-Cq), 130.3 (aryl-Cq), 129.5 (aryl- $C H), 129.4$ (aryl- $C H), 129.3$ (aryl- $C H), 129.0$ (aryl-Cq), 128.9 (aryl-Cq), 128.7 (aryl- $\mathrm{CH}), 127.8(\operatorname{aryl}-\mathrm{CH}), 127.7(\operatorname{aryl}-\mathrm{CH}), 127.6(\operatorname{aryl}-\mathrm{CH}), 127.3\left(\operatorname{aryl}-\mathrm{CH}, \mathrm{OCH}_{2} P h\right)$, 127.1 (aryl-Cq, $\left.\mathrm{OCH}_{2} P h\right), 126.6\left(\operatorname{aryl}-\mathrm{CH}, \mathrm{OCH}_{2} P h\right), 126.2\left(\operatorname{aryl}-\mathrm{CH}, \mathrm{OCH}_{2} P h\right), 125.2$ (aryl$C q), 125.1$ (aryl- $C H), 124.7$ (aryl- $C H), 124.6$ (aryl- $C H), 124.5$ (aryl- $C H), 123.7$ (aryl- $C H$ ), $122.9(\operatorname{aryl}-\mathrm{CH}), 113.3(\operatorname{aryl}-\mathrm{Cq}), 75.9\left(\mathrm{OCH}_{2} \mathrm{Ph}\right)$. Anal. Calcd for $\mathrm{C}_{68} \mathrm{H}_{51} \mathrm{NO}_{2} \mathrm{Si}_{2}: \mathrm{C}, 84.17$; H, 5.30; N, 1.44. Found: C, 84.55; H, 5.22; N, 1.47. Yellow crystals of b suitable for X-ray diffraction analysis were obtained by prolonged crystallization from $\mathrm{CHCl}_{3}$ at room temperature.

Proligand c. A solution of 2-bromo-6-(2-(methoxymethoxy)-3(triphenylsilyl)naphthalen-1-yl)pyridine $(1.00 \mathrm{~g}, 1.66 \mathrm{mmol})$, (3-methoxynaphthalen-2yl)boronic acid ( $0.335 \mathrm{~g}, 1.66 \mathrm{mmol}), \mathrm{Na}_{2} \mathrm{CO}_{3}$ ( $20 \mathrm{~mL}$ of a $2 \mathrm{M}$ solution in water), $\mathrm{EtOH}$ (20 $\mathrm{mL})$ and toluene $(50 \mathrm{~mL})$ was stirred under argon. After $20 \mathrm{~min}, \mathrm{Pd}\left(\mathrm{PPh}_{3}\right)_{4}(0.095 \mathrm{~g}, 0.08$ mmol) was added and the solution was refluxed at $90{ }^{\circ} \mathrm{C}$ for $48 \mathrm{~h}$. The reaction mixture was 
allowed to cool down to room temperature, added to water $(50 \mathrm{~mL})$, and extracted with $\mathrm{CH}_{2} \mathrm{Cl}_{2}(3 \times 50 \mathrm{~mL})$. The combined organic layers were dried over magnesium sulfate and evaporated to yield a yellow solid. This solid was dissolved in a mixture of concentrated $\mathrm{HCl}$ $(20 \mathrm{~mL}), \mathrm{CHCl}_{3}(30 \mathrm{~mL})$, and $\mathrm{EtOH}(40 \mathrm{~mL})$, and the solution was refluxed for $4 \mathrm{~h}$. The reaction mixture was cooled to $0{ }^{\circ} \mathrm{C}$ and then carefully diluted with a concentrated solution of $\mathrm{NaOH}(50 \mathrm{~mL})$. Then, a concentrated solution of $\mathrm{NH}_{4} \mathrm{Cl}$ was added to adjust the $\mathrm{pH}$ value to 7-8. The product was extracted with $\mathrm{CH}_{2} \mathrm{Cl}_{2}(3 \times 20 \mathrm{~mL})$, and the combined organic extracts were dried over $\mathrm{MgSO}_{4}$ and evaporated to afford desired compound as a yellow solid. This material was recrystallized using a $\mathrm{Et}_{2} \mathrm{O} / \mathrm{CH}_{2} \mathrm{Cl}_{2}$ mixture (9:1) to afford pure $\mathbf{c}(0.70 \mathrm{~g}, 66 \%)$. ${ }^{1} \mathrm{H}$ NMR $\left(400 \mathrm{MHz}, \mathrm{CDCl}_{3}, 298 \mathrm{~K}\right): \delta 12.56(\mathrm{br} \mathrm{s}, 1 \mathrm{H}, \mathrm{OH}), 8.25\left(\mathrm{~d},{ }^{3} J_{H-H}=8.5,1 \mathrm{H}\right.$, aryl$\mathrm{CH}), 8.06\left(\mathrm{~s}, 1 \mathrm{H}\right.$, aryl-CH), $7.95\left(\mathrm{t},{ }^{3} J_{H-H}=7.8,1 \mathrm{H}\right.$, aryl-CH $), 7.87\left(\mathrm{~d},{ }^{3} J_{H-H}=7.9,1 \mathrm{H}\right.$, aryl$\mathrm{CH}), 7.83-7.81(\mathrm{~m}, 2 \mathrm{H}$, aryl-CH$), 7.74\left(\mathrm{~d},{ }^{3} J_{H-H}=6.8,7 \mathrm{H}\right.$, aryl-CH $), 7.69-7.67(\mathrm{~m}, 2 \mathrm{H}$, aryl$\mathrm{CH}), 7.49-7.46(\mathrm{~m}, 2 \mathrm{H}$, aryl-CH$), 7.44-7.37(\mathrm{~m}, 10 \mathrm{H}$, aryl-CH$), 7.29\left(\mathrm{t},{ }^{3} J_{H-H}=7.4,1 \mathrm{H}\right.$, aryl$\mathrm{CH}), 7.18(\mathrm{~s}, 1 \mathrm{H}$, aryl- $\mathrm{CH}), 3.57\left(\mathrm{~s}, 3 \mathrm{H}, \mathrm{OCH}_{3}\right) .{ }^{13} \mathrm{C} \mathrm{NMR}\left(100 \mathrm{MHz}, \mathrm{CDCl}_{3}, 298 \mathrm{~K}\right): \delta$ 159.6 (aryl-Cq), 155.9 (aryl-Cq), 155.5 (aryl-Cq), 155.2 (aryl-Cq), 142.3 (aryl-CH), 137.5 $(\operatorname{aryl}-\mathrm{CH}), 136.5(\operatorname{aryl}-\mathrm{CH}), 135.2(\operatorname{aryl}-\mathrm{CH}), 135.1(\operatorname{aryl}-\mathrm{CH}), 134.8(\operatorname{aryl}-\mathrm{Cq}), 133.2$ (aryl$C q), 130.7$ (aryl-CH), 130.6 (aryl-CH), 129.5 (aryl-Cq), 129.4 (aryl-CH), 129.2 (aryl-CH), 128.8 (aryl-Cq), 128.6 (aryl-Cq), 128.1 (aryl- $C H), 127.7$ (aryl- $C H), 127.1$ (aryl- $C H), 126.4$ $(\operatorname{aryl}-\mathrm{CH}), 125.4(\operatorname{aryl}-\mathrm{Cq}), 124.3(\operatorname{aryl}-\mathrm{CH}), 124.2(\operatorname{aryl}-\mathrm{CH}), 123.5(\operatorname{aryl}-\mathrm{CH}), 122.8$ (aryl$C H), 121.9(\operatorname{aryl}-\mathrm{CH}), 114.7$ (aryl- $C \mathrm{q}), 106.3(\operatorname{aryl}-\mathrm{CH}), 55.0\left(\mathrm{CH}_{3}\right)$. Anal. Calcd for $\mathrm{C}_{44} \mathrm{H}_{33} \mathrm{NO}_{2} \mathrm{Si}: \mathrm{C}, 83.12 ; \mathrm{H}, 5.23 ; \mathrm{N}, 2.20$. Found: C, 83.10; H, 5.19; N, 2.28.

Proligand d. Using a procedure similar to that described above for $\mathbf{c}$, compound $\mathbf{d}$ was obtained from 2-bromo-6-(2-(methoxymethoxy)-3-(triphenylsilyl)naphthalen-1yl)pyridine (1.00 g, $1.66 \mathrm{mmol}), 2$-methoxyphenylboronic acid $(0.252 \mathrm{~g}, 1.66 \mathrm{mmol})$ and $\mathrm{Pd}\left(\mathrm{PPh}_{3}\right)_{4}(0.095 \mathrm{~g}, 0.08 \mathrm{mmol})$. The resulting yellow solid was washed with pentane and recrystallized from $\mathrm{CH}_{2} \mathrm{Cl}_{2}$ to afford $\mathbf{d}(0.91 \mathrm{~g}, 93 \%) .{ }^{1} \mathrm{H} \mathrm{NMR}\left(400 \mathrm{MHz}, \mathrm{CDCl}_{3}, 298 \mathrm{~K}\right): \delta$ 
$12.55(\mathrm{~s}, 1 \mathrm{H}, \mathrm{OH}), 8.24\left(\mathrm{~d},{ }^{3} J_{H-H}=8.5,1 \mathrm{H}\right.$, aryl- $\left.\mathrm{CH}\right), 7.92\left(\mathrm{t},{ }^{3} J_{H-H}=7.8,1 \mathrm{H}\right.$, aryl-CH$), 7.84$ $\left(\mathrm{d},{ }^{3} J_{H-H}=8.9,2 \mathrm{H}\right.$, aryl-CH), $7.74\left(\mathrm{~d},{ }^{3} J_{H-H}=7.7,6 \mathrm{H}\right.$, aryl-CH $), 7.67\left(\mathrm{~d},{ }^{3} J_{H-H}=8.1,1 \mathrm{H}\right.$, aryl$\mathrm{CH}), 7.61-7.57\left(\mathrm{~m}, 2 \mathrm{H}\right.$, aryl-CH), 7.48-7.38 (m, 11H, aryl-CH), $7.29\left(\mathrm{t},{ }^{3} J_{H-H}=7.4,1 \mathrm{H}\right.$, aryl$\mathrm{CH}), 7.06\left(\mathrm{t},{ }^{3} J_{H-H}=7.5,1 \mathrm{H}, \operatorname{aryl}-\mathrm{CH}\right), 6.95\left(\mathrm{~d},{ }^{3} J_{H-H}=8.3,1 \mathrm{H}, \operatorname{aryl}-\mathrm{CH}\right), 3.49(\mathrm{~s}, 3 \mathrm{H}$, $\left.\mathrm{OCH}_{3}\right) .{ }^{13} \mathrm{C} \mathrm{NMR}\left(125 \mathrm{MHz}, \mathrm{CDCl}_{3}, 298 \mathrm{~K}\right): \delta 159.6$ (aryl- $\left.\mathrm{Cq}\right), 157.0$ (aryl-Cq), 155.8 (arylCq), 155.6 (aryl-Cq), 142.3 (aryl-CH), 137.4 (aryl-CH), 136.5 (aryl-CH), 135.2 (aryl-Cq), 133.3 (aryl-Cq), 130.7 (aryl- $C H), 130.4$ (aryl-CH), 129.4 (aryl- $C H), 129.2(\operatorname{aryl}-C H), 128.9$ (aryl-Cq), 127.9 (aryl-Cq), 127.7 (aryl-CH), 127.6 (aryl-CH), 125.3 (aryl-Cq), 124.0 (aryl$C H$ ), 123.5 (aryl- $C H$ ), 122.7 (aryl- $C H), 121.7$ (aryl- $C H), 120.8$ (aryl-CH), 114.7 (aryl-Cq), 111.5 (aryl- $\mathrm{CH}), 54.9\left(\mathrm{CH}_{3}\right)$. Anal. Calcd for $\mathrm{C}_{44} \mathrm{H}_{33} \mathrm{NO}_{2} \mathrm{Si}$ : C, 82.02; H, 5.33; N, 2.39. Found: C, 82.06; H, 5.40; N, 2.29.

Proligand e. A solution of 6-(2-hydroxy-3-(triphenylsilyl)naphthalen-1yl)picolinaldehyde $(1.20 \mathrm{~g}, 2.36 \mathrm{mmol})$ and 2,6-diisopropylaniline $(0.54 \mathrm{~g}, 3.07 \mathrm{mmol})$ in THF (50 mL) containing $3 \AA$ molecular sieves and a catalytic amount of TsOH was heated to reflux under argon for $12 \mathrm{~h}$. After filtration and removal of the volatiles under vacuum, the crude material was recrystallized from a $\mathrm{CH}_{2} \mathrm{Cl}_{2} /$ pentane mixture (1:1) to afford e as a microcrystalline yellow solid (1.20 g, 76\%). ${ }^{1} \mathrm{H} \mathrm{NMR}$ (400 MHz, $\left.\mathrm{CDCl}_{3}, 298 \mathrm{~K}\right): \delta 11.86$ (br s, $1 \mathrm{H}, \mathrm{OH}), 8.19(\mathrm{~s}, 1 \mathrm{H}, \mathrm{CH}=\mathrm{N}), 8.15-8.12(\mathrm{~m}, 1 \mathrm{H}, \operatorname{aryl}-\mathrm{CH}), 8.05\left(\mathrm{~d},{ }^{3} J_{H-H}=8.5,1 \mathrm{H}\right.$, aryl$\mathrm{CH}), 7.92-7.91(\mathrm{~m}, 2 \mathrm{H}$, aryl-CH), $7.73(\mathrm{~s}, 1 \mathrm{H}, \operatorname{aryl}-\mathrm{CH}), 7.59-7.55(\mathrm{~m}, 6 \mathrm{H}$, aryl-CH), 7.31-7.18 (m, 12H, aryl-CH), 7.07-7.03 (m, 3H, aryl-CH), 2.87-2.84 (sept, ${ }^{3} J_{H-H}=7.4,2 \mathrm{H}$, $\left.\mathrm{CH}\left(\mathrm{CH}_{3}\right)_{2}\right), 1.07\left(\mathrm{~d},{ }^{3} J_{H-H}=7.4,12 \mathrm{H}, \mathrm{CH}\left(\mathrm{CH}_{3}\right)_{2}\right) .{ }^{13} \mathrm{C} \mathrm{NMR}\left(100 \mathrm{MHz}, \mathrm{CDCl}_{3}, 298 \mathrm{~K}\right): \delta$ $161.8(C \mathrm{H}=\mathrm{N}), 159.4(\operatorname{aryl}-C \mathrm{q}), 156.9$ (aryl-Cq), 152.7 (aryl-Cq), 148.3 (aryl-Cq), 142.9 (aryl-CH), 137.8 (aryl-CH), 137.1 (aryl-Cq), 136.6 (aryl-CH), 136.5 (aryl-CH), 134.7 (arylCq), 133.2 (aryl-Cq), 129.5 (aryl- $C H), 129.4(\operatorname{aryl}-C H), 127.9$ (aryl- $C H), 127.7$ (aryl-CH), 125.1 (aryl-Cq), 124.7 (aryl- $C H), 123.3$ (aryl-CH), 123.2 (aryl- $C H), 119.5$ (aryl- $C H), 113.9$ 
(aryl-Cq), $28.0\left(\mathrm{CH}\left(\mathrm{CH}_{3}\right)_{2}\right), 22.4\left(\mathrm{CH}\left(\mathrm{CH}_{3}\right)_{2}\right)$. Anal. Calcd for $\mathrm{C}_{46} \mathrm{H}_{42} \mathrm{~N}_{2} \mathrm{OSi}$ : C, 82.84; $\mathrm{H}$, 6.35; N, 4.20. Found: C, 82.80; H, 6.39; N, 4.27.

Proligand f. To a solution of e (1.00 g, $1.49 \mathrm{mmol})$ in anhydrous, degassed $\mathrm{Et}_{2} \mathrm{O}$ (5 $\mathrm{mL})$ cooled to $-30{ }^{\circ} \mathrm{C}$ under argon was added phenyllithium $(2.25 \mathrm{~mL}$ of a $2 \mathrm{M}$ solution in dibutyl ether, $4.49 \mathrm{mmol})$. After warming to room temperature, the reaction mixture was stirred for $12 \mathrm{~h}$. The reaction was then quenched with aqueous $\mathrm{NH}_{4} \mathrm{Cl}$. The product was extracted with $\mathrm{Et}_{2} \mathrm{O}(3 \times 20 \mathrm{~mL})$, and the combined organic extracts were dried over $\mathrm{MgSO}_{4}$ and evaporated to afford $\mathbf{f}$ as a microcrystalline yellow solid (1.00 g, 90\%). ${ }^{1} \mathrm{H}$ NMR (500 $\left.\mathrm{MHz}, \mathrm{CDCl}_{3}, 298 \mathrm{~K}\right): \delta 11.66$ (br s, $\left.1 \mathrm{H}, \mathrm{OH}\right), 8.17\left(\mathrm{~d},{ }^{3} J_{H-H}=8.5,1 \mathrm{H}, \operatorname{aryl}-\mathrm{CH}\right), 7.88(\mathrm{~s}, 1 \mathrm{H}$, $\operatorname{aryl-CH}), 7.79\left(\mathrm{~d},{ }^{3} J_{H-H}=4.2,2 \mathrm{H}, \operatorname{aryl}-\mathrm{C} H\right), 7.71-7.68(\mathrm{~m}, 7 \mathrm{H}, \operatorname{aryl}-\mathrm{CH}), 7.67-7.65(\mathrm{~m}, 1 \mathrm{H}$, aryl-CH), 7.50-7.46 (m, 5H, aryl-CH), 7.43-7.39 (m, 6H, aryl-CH), 7.33-7.31 (m, 2H, aryl$\mathrm{CH})$, 7.23-7.20 (m, 3H, aryl-CH), 7.05-7.02 (m, 3H, aryl-CH), $5.24(\mathrm{~s}, 1 \mathrm{H}, \mathrm{CHPh})$, 2.95-2.90 (sept, $\left.{ }^{3} J_{H-H}=6.8,2 \mathrm{H}, \mathrm{CH}\left(\mathrm{CH}_{3}\right)_{2}\right), 1.05\left(\mathrm{~d},{ }^{3} J_{H-H}=6.8,6 \mathrm{H}, \mathrm{CH}\left(\mathrm{CH}_{3}\right)_{2}\right), 1.02\left(\mathrm{~d},{ }^{3} J_{H-}\right.$ $\left.{ }_{H}=6.7,6 \mathrm{H}, \mathrm{CH}\left(\mathrm{CH}_{3}\right)_{2}\right) .{ }^{13} \mathrm{C} \mathrm{NMR}\left(125 \mathrm{MHz}, \mathrm{CDCl}_{3}, 298 \mathrm{~K}\right): \delta 161.1(\operatorname{aryl}-\mathrm{Cq}), 159.7$ (arylCq), 156.7 (aryl-Cq), 142.4 (aryl-CH), 142.1 (aryl-Cq), 141.9 (aryl-Cq), 141.1 (aryl-Cq), 137.4 (aryl-CH), 136.6 (aryl-CH), 134.8 (aryl-Cq), 133.1 (aryl-Cq), 129.4 (aryl-CH), 129.2 (aryl- $\mathrm{CH}), 128.9$ (aryl- $\mathrm{CH}), 128.7$ (aryl- $\mathrm{CH}), 128.6$ (aryl- $\mathrm{CH}), 128.5$ (aryl- $\mathrm{CH}), 127.6$ (aryl$C H), 127.4(\operatorname{aryl}-C H), 127.2(\operatorname{aryl}-C H), 127.1(\operatorname{aryl}-C H), 126.1$ (aryl- $C q), 125.4$ (aryl-Cq), 124.5 (aryl- $\mathrm{CH}), 123.7$ (aryl- $\mathrm{CH}), 123.6$ (aryl- $\mathrm{CH}), 123.3$ (aryl- $\mathrm{CH}), 122.8$ (aryl- $\mathrm{CH}), 119.9$ $(\operatorname{aryl}-\mathrm{CH}), \quad 113.9 \quad(\operatorname{aryl}-\mathrm{Cq}), \quad 69.6 \quad(\mathrm{CHPh}), \quad 27.7 \quad\left(\mathrm{CH}\left(\mathrm{CH}_{3}\right)_{2}\right), \quad 24.1 \quad\left(\mathrm{CH}\left(\mathrm{CH}_{3}\right)_{2}\right), \quad 24.0$ $\left(\mathrm{CH}\left(\mathrm{CH}_{3}\right)_{2}\right)$. Anal. Calcd for $\mathrm{C}_{52} \mathrm{H}_{48} \mathrm{~N}_{2} \mathrm{OSi}$ : C, 83.83; H, 6.49; N, 3.76. Found: C, 83.90; H, $6.45 ; \mathrm{N}, 3.71$.

Complex 1a. A Schlenk flask was charged with proligand a $(0.100 \mathrm{~g}, 0.112 \mathrm{mmol})$ and dried toluene $(c a .10 \mathrm{~mL})$ was transferred in. $\mathrm{ZnEt}_{2}(0.12 \mathrm{~mL}$ of a $1.0 \mathrm{M}$ solution in toluene, $0.12 \mathrm{mmol}$ ) was added to the reaction mixture at $-78{ }^{\circ} \mathrm{C}$. The reaction mixture was gently warmed to room temperature and stirred $12 \mathrm{~h}$. The solution was filtered, evaporated, 
and the residue was washed with pentane and dried under vacuum to give 1a as a yellow microcrystalline material $(0.100 \mathrm{~g}, 90 \%) .{ }^{1} \mathrm{H}$ NMR (500 MHz, toluene- $\left.d_{8}, 253 \mathrm{~K}\right): \delta 8.31$ (s, $1 \mathrm{H}$, aryl-CH), $8.07(\mathrm{~s}, 1 \mathrm{H}$, aryl- $\mathrm{CH}), 7.96-7.94(\mathrm{~m}, 6 \mathrm{H}, \operatorname{aryl}-\mathrm{CH}), 7.91\left(\mathrm{~d},{ }^{3} J_{H-H}=8.5,1 \mathrm{H}\right.$, $\operatorname{aryl}-\mathrm{CH}), 7.79\left(\mathrm{~d},{ }^{3} J_{H-H}=8.3,1 \mathrm{H}, \operatorname{aryl}-\mathrm{CH}\right), 7.74\left(\mathrm{~d},{ }^{3} J_{H-H}=7.2,6 \mathrm{H}, \operatorname{aryl}-\mathrm{C} H\right), 7.37\left(\mathrm{~d},{ }^{3} J_{H-H}\right.$ $=8.1,1 \mathrm{H}, \operatorname{aryl}-\mathrm{CH}), 7.33\left(\mathrm{~d},{ }^{3} J_{H-H}=7.9,1 \mathrm{H}\right.$, aryl- $\left.\mathrm{CH}\right), 7.26\left(\mathrm{~d},{ }^{3} J_{H-H}=8.1,1 \mathrm{H}\right.$, aryl-CH$)$, $7.22-7.16\left(\mathrm{~m}, 14 \mathrm{H}\right.$, aryl-CH), $7.05\left(\mathrm{t},{ }^{3} J_{H-H}=7.6,8 \mathrm{H}\right.$, aryl-CH), $6.77\left(\mathrm{t},{ }^{3} J_{H-H}=7.9,1 \mathrm{H}\right.$, aryl$\mathrm{CH}), 6.45\left(\mathrm{~d},{ }^{3} J_{H-H}=7.5,1 \mathrm{H}, \operatorname{aryl}-\mathrm{CH}\right), 2.34\left(\mathrm{~s}, 3 \mathrm{H}, \mathrm{OCH}_{3}\right), 0.45\left(\mathrm{t},{ }^{3} J_{H-H}=8.1,3 \mathrm{H}\right.$, $\left.\mathrm{ZnCH}_{2} \mathrm{CH}_{3}\right),-0.06-0.14\left(\mathrm{~m}, 1 \mathrm{H}, \mathrm{ZnCH}_{2} \mathrm{CH}_{3}\right),-0.53--0.46\left(\mathrm{~m}, 1 \mathrm{H}, \mathrm{ZnCH}_{2} \mathrm{CH}_{3}\right) .{ }^{13} \mathrm{C}\left\{{ }^{1} \mathrm{H}\right\}$ NMR (125 MHz, toluene- $\left.d_{8}, 298 \mathrm{~K}\right): \delta 169.3$ (aryl-Cq), 158.1 (aryl-Cq), 143.8 (aryl-CH), $142.2(\operatorname{aryl}-\mathrm{CH}), 137.0$ (aryl- $\mathrm{CH}), 136.8$ (aryl- $\mathrm{CH}), 130.1$ (aryl- $\mathrm{CH}), 129.5$ (aryl- $\mathrm{CH}), 129.2$ (aryl- $\mathrm{CH}), 128.9(\operatorname{aryl}-\mathrm{CH}), 128.8(\operatorname{aryl}-\mathrm{CH}), 128.1$ (aryl- $\mathrm{CH}), 128.0(\operatorname{aryl}-\mathrm{CH}), 127.7$ (aryl$\mathrm{CH}), 127.2(\operatorname{aryl}-\mathrm{CH}), 127.0(\operatorname{aryl}-\mathrm{CH}), 125.7$ (aryl- $\mathrm{CH}), 124.5$ (aryl- $\mathrm{CH}), 124.2$ (aryl- $\mathrm{CH})$, 122.7 (aryl- $\mathrm{CH}), 121.1$ (aryl- $\mathrm{CH}), 113.7$ (aryl- $\mathrm{CH}), 59.2\left(\mathrm{OCH}_{3}\right), 11.8\left(\mathrm{ZnCH}_{2} \mathrm{CH}_{3}\right),-1.8$ $\left(\mathrm{ZnCH}_{2} \mathrm{CH}_{3}\right)$ Anal. Calcd for $\mathrm{C}_{64} \mathrm{H}_{51} \mathrm{NO}_{2} \mathrm{Si}_{2} \mathrm{Zn}: \mathrm{C}, 77.83 ; \mathrm{H}, 5.20 ; \mathrm{N}, 1.42$. Found: C, 77.95; $\mathrm{H}, 5.02 ; \mathrm{N}, 1.53$. Yellow crystals of 1a suitable for X-ray diffraction analysis were obtained by prolonged crystallization from $\mathrm{C}_{7} \mathrm{H}_{8} /$ heptane mixture (1:1) at room temperature.

Complex 1c. Using a procedure similar to that described above for 1a, compound 1c was obtained from c $(0.100 \mathrm{~g}, 0.157 \mathrm{mmol})$ and $\mathrm{ZnEt}_{2}(0.17 \mathrm{~mL}$ of a $1.0 \mathrm{M}$ solution in toluene, $0.17 \mathrm{mmol})$ and isolated as a yellow microcrystalline material $(0.111 \mathrm{~g}, 97 \%) .{ }^{1} \mathrm{H}$ NMR $\left(500 \mathrm{MHz}\right.$, THF- $\left.d_{8}, 298 \mathrm{~K}\right): \delta$ 7.95-7.91 (m, 2H, aryl-CH), 7.80-7.74 (m, 4H, aryl$\mathrm{CH}), 7.71(\mathrm{~s}, 1 \mathrm{H}, \operatorname{aryl}-\mathrm{CH}), 7.63\left(\mathrm{~d},{ }^{3} J_{H-H}=7.1,6 \mathrm{H}, \operatorname{aryl}-\mathrm{CH}\right), 7.54\left(\mathrm{~d},{ }^{3} J_{H-H}=7.8,1 \mathrm{H}\right.$, aryl$\mathrm{CH}), 7.46-7.44(\mathrm{~m}, 2 \mathrm{H}, \operatorname{aryl}-\mathrm{CH}), 7.37(\mathrm{~s}, 1 \mathrm{H}, \operatorname{aryl}-\mathrm{CH}), 7.33-7.32(\mathrm{~m}, 1 \mathrm{H}, \operatorname{aryl}-\mathrm{CH})$, 7.26-7.21 (m, 10H, aryl-CH), $6.98\left(\mathrm{t},{ }^{3} J_{H-H}=7.4,1 \mathrm{H}\right.$, aryl-CH), $3.90\left(\mathrm{~s}, 3 \mathrm{H}, \mathrm{OCH}_{3}\right), 0.52(\mathrm{t}$, $\left.{ }^{3} J_{H-H}=8.0,3 \mathrm{H}, \mathrm{ZnCH}_{2} \mathrm{CH}_{3}\right),-0.61\left(\mathrm{q},{ }^{3} J_{H-H}=8.0,2 \mathrm{H}, \mathrm{ZnCH}_{2} \mathrm{CH}_{3}\right) .{ }^{13} \mathrm{C} \mathrm{NMR}(125 \mathrm{MHz}$, THF- $d_{8}, 298 \mathrm{~K}$ ): $\delta 170.8$ (aryl-Cq), 159.6 (aryl-Cq), 156.9 (aryl-Cq), 155.7 (aryl-Cq), 143.3 (aryl-CH), $138.0(\operatorname{aryl}-\mathrm{CH}), 137.6(\operatorname{aryl}-\mathrm{Cq}), 137.4$ (aryl-CH), 137.3 (aryl-CH), 136.9 (aryl- 
Cq), 136.1 (aryl-Cq), 132.9 (aryl-CH), 131.8 (aryl-Cq), 130.7 (aryl-Cq), 129.7 (aryl-CH), 129.6 (aryl-Cq), 129.5 (aryl-Cq), 129.2 (aryl- $C H), 128.9$ (aryl- $C H), 128.4(\operatorname{aryl}-C H), 128.1$ (aryl- $\mathrm{CH}), 128.0(\operatorname{aryl}-\mathrm{CH}), 127.9$ (aryl- $\mathrm{CH}), 127.8$ (aryl- $C \mathrm{q}), 127.4$ (aryl- $\mathrm{CH}), 127.3$ (arylCH), 126.0 (aryl- $C q), 124.9$ (aryl- $C H$ ), 124.2 (aryl- $C H$ ), 122.9 (aryl- $C H), 120.8$ (aryl- $C H$ ), 114.3 (aryl-Cq), 106.9 (aryl- $C \mathrm{H}), 55.85\left(\mathrm{OCH}_{3}\right), 12.75\left(\mathrm{ZnCH}_{2} \mathrm{CH}_{3}\right),-1.15\left(\mathrm{ZnCH}_{2} \mathrm{CH}_{3}\right)$. Anal. Calcd for $\mathrm{C}_{46} \mathrm{H}_{37} \mathrm{NO}_{2} \mathrm{SiZn}: \mathrm{C}, 75.76 ; \mathrm{H}, 5.11 ; \mathrm{N}, 1.92$. Found: $\mathrm{C}, 75.63 ; \mathrm{H}, 5.13 ; \mathrm{N}$, 1.95. Yellow crystals of 1c suitable for X-ray diffraction analysis were obtained by prolonged crystallization from a THF/hexane mixture $(1: 1)$ at room temperature.

Complex 1d. Using a procedure similar to that described above for 1a, compound 1d was obtained from proligand $\mathbf{d}(0.100 \mathrm{~g}, 0.170 \mathrm{mmol})$ and $\mathrm{ZnEt}_{2}(0.19 \mathrm{~mL}$ of a $1.0 \mathrm{M}$ solution in toluene, $0.19 \mathrm{mmol})$ and isolated as a yellow microcrystalline material $(0.080 \mathrm{~g}$, 69\%). ${ }^{1} \mathrm{H}$ NMR $\left(500 \mathrm{MHz}, \mathrm{C}_{6} \mathrm{D}_{6}, 298 \mathrm{~K}\right): \delta 8.11(\mathrm{~s}, 1 \mathrm{H}$, aryl-CH), 7.98-7.96 (m, 6H, aryl$\mathrm{CH}), 7.86\left(\mathrm{~d},{ }^{3} J_{H-H}=8.5,1 \mathrm{H}, \operatorname{aryl}-\mathrm{CH}\right), 7.44\left(\mathrm{~d},{ }^{3} J_{H-H}=8.2,1 \mathrm{H}, \operatorname{aryl}-\mathrm{CH}\right), 7.36\left(\mathrm{~d},{ }^{3} J_{H-H}=\right.$ 8.0, $1 \mathrm{H}$, aryl-CH), 7.21-7.20 (m, 8H, aryl-CH), $7.17\left(\mathrm{~d},{ }^{3} J_{H-H}=7.9,1 \mathrm{H}\right.$, aryl-CH), $7.09(\mathrm{~d}$, ${ }^{3} J_{H-H}=7.3,1 \mathrm{H}$, aryl-CH$), 7.02\left(\mathrm{~d},{ }^{3} J_{H-H}=7.6,1 \mathrm{H}, \operatorname{aryl}-\mathrm{CH}\right), 6.98\left(\mathrm{~d},{ }^{3} J_{H-H}=7.1,1 \mathrm{H}\right.$, aryl$\mathrm{CH}), 6.93\left(\mathrm{~d},{ }^{3} J_{H-H}=7.9,1 \mathrm{H}\right.$, aryl-CH$), 6.85\left(\mathrm{t},{ }^{3} J_{H-H}=7.9,1 \mathrm{H}, \operatorname{aryl}-\mathrm{CH}\right), 6.75\left(\mathrm{t},{ }^{3} J_{H-H}=7.4\right.$, $1 \mathrm{H}$, aryl-CH $), 6.50\left(\mathrm{~d},{ }^{3} J_{H-H}=7.6,1 \mathrm{H}, \operatorname{aryl}-\mathrm{C} H\right), 6.40\left(\mathrm{~d},{ }^{3} J_{H-H}=8.3,1 \mathrm{H}, \operatorname{aryl}-\mathrm{CH}\right), 3.12(\mathrm{~s}$, $\left.3 \mathrm{H}, \mathrm{OCH}_{3}\right), 0.78\left(\mathrm{t},{ }^{3} \mathrm{~J}_{\mathrm{H}-\mathrm{H}}=8.1,3 \mathrm{H}, \mathrm{ZnCH}_{2} \mathrm{CH}_{3}\right), 0.02\left(\mathrm{~s}, 2 \mathrm{H}, \mathrm{ZnCH}_{2} \mathrm{CH}_{3}\right) .{ }^{13} \mathrm{C}$ NMR $(125$ MHz, $\left.\mathrm{C}_{6} \mathrm{D}_{6}, 298 \mathrm{~K}\right): \delta 170.2$ (aryl-Cq), 156.9 (aryl-Cq), 155.4 (aryl-Cq), 153.9 (aryl-Cq), 144.5 (aryl-CH), 138.2 (aryl- $C H), 137.2$ (aryl-Cq), 137.1 (aryl-CH), 136.2 (aryl-Cq), 132.5 (aryl-Cq), 131.3 (aryl-CH), 130.8 (aryl- $C H), 129.9$ (aryl- $C H), 129.3$ (aryl-Cq), 129.1 (aryl$C \mathrm{H}), 128.6(\operatorname{aryl}-\mathrm{Cq}), 128.3(\operatorname{aryl}-\mathrm{CH}), 128.2$ (aryl-Cq), 127.9 (aryl- $\mathrm{CH}), 127.4$ (aryl- $C \mathrm{H})$, 126.9 (aryl-CH), 125.7 (aryl- $C \mathrm{q}), 123.3(\operatorname{aryl}-\mathrm{CH}), 123.0(\operatorname{aryl}-\mathrm{CH}), 121.8(\operatorname{aryl}-\mathrm{CH}), 121.5$ $(\operatorname{aryl}-\mathrm{CH}), \quad 114.2(\operatorname{aryl}-\mathrm{Cq}), 113.6(\operatorname{aryl}-\mathrm{CH}), \quad 56.4\left(\mathrm{OCH}_{3}\right), \quad 12.3 \quad\left(\mathrm{ZnCH}_{2} \mathrm{CH}_{3}\right),-2.44$ $\left(\mathrm{ZnCH}_{2} \mathrm{CH}_{3}\right)$. Anal. Calcd for $\mathrm{C}_{42} \mathrm{H}_{35} \mathrm{NO}_{2} \mathrm{SiZn}: \mathrm{C}, 74.27 ; \mathrm{H}, 5.19 ; \mathrm{N}, 2.06$. Found: C, 74.51; 
$\mathrm{H}, 5.22 ; \mathrm{N}, 2.13$. Yellow crystals of $\mathbf{1 d}$ suitable for X-ray diffraction analysis were obtained by prolonged crystallization from a $\mathrm{C}_{6} \mathrm{H}_{6} /$ hexane mixture (1:1) at room temperature.

Complex 2c. Using a procedure similar to that described above for 1a, compound $\mathbf{2 c}$ was obtained from proligand $\mathbf{c}(0.100 \mathrm{~g}, 0.157 \mathrm{mmol})$ and $\mathrm{Zn}\left[\mathrm{N}\left(\mathrm{SiMe}_{3}\right)_{2}\right]_{2}(0.067 \mathrm{~g}, 0.173$ mmol) and isolated as a yellow microcrystalline material $(0.110 \mathrm{~g}, 81 \%) .{ }^{1} \mathrm{H}$ NMR (500 MHz, $\left.\mathrm{C}_{6} \mathrm{D}_{6}, 298 \mathrm{~K}\right): \delta 8.09\left(\mathrm{~s}, 1 \mathrm{H}\right.$, aryl-CH), $7.98\left(\mathrm{~d},{ }^{3} J_{H-H}=7.4,1 \mathrm{H}\right.$, aryl-CH), $7.93\left(\mathrm{~d},{ }^{3} J_{H-H}\right.$ $=7.5,6 \mathrm{H}$, aryl- $\mathrm{CH}), 7.72(\mathrm{~s}, 1 \mathrm{H}$, aryl- $\mathrm{CH}), 7.55\left(\mathrm{~d},{ }^{3} J_{H-H}=8.0,1 \mathrm{H}, \operatorname{aryl}-\mathrm{CH}\right), 7.52\left(\mathrm{~d},{ }^{3} J_{H-H}=\right.$ 8.3, $1 \mathrm{H}$, aryl- $\mathrm{CH}), 7.48\left(\mathrm{~d},{ }^{3} J_{H-H}=8.1,1 \mathrm{H}\right.$, aryl- $\left.\mathrm{C} H\right), 7.32\left(\mathrm{~d},{ }^{3} J_{H-H}=8.0,1 \mathrm{H}\right.$, aryl-CH$)$, $7.23-7.20\left(\mathrm{~m}, 12 \mathrm{H}\right.$, aryl-CH), $6.97\left(\mathrm{t},{ }^{3} J_{H-H}=7.4,2 \mathrm{H}\right.$, aryl- $\left.\mathrm{CH}\right), 6.89\left(\mathrm{t}^{3} J_{H-H}=7.9,1 \mathrm{H}\right.$, aryl$\mathrm{CH}), 6.64\left(\mathrm{t},{ }^{3} J_{H-H}=7.6,1 \mathrm{H}\right.$, aryl- $\left.\mathrm{CH}\right), 3.15\left(\mathrm{~s}, 3 \mathrm{H}, \mathrm{OCH}_{3}\right), 0.14\left(\mathrm{~s}, 18 \mathrm{H}, \mathrm{ZnN}\left(\mathrm{SiMe}_{3}\right)_{2}\right) .{ }^{13} \mathrm{C}$ NMR (125 MHz, $\left.\mathrm{C}_{6} \mathrm{D}_{6}, 298 \mathrm{~K}\right): \delta 171.5$ (aryl-Cq), 158.0 (aryl-Cq), 153.1 (aryl-Cq), 152.8 (aryl-Cq), $144.9(\operatorname{aryl}-\mathrm{CH}), 138.1(\operatorname{aryl}-\mathrm{CH}), 137.1(\operatorname{aryl}-\mathrm{CH}), 136.9$ (aryl-Cq), 136.3 (arylCq), 134.8 (aryl-Cq), 131.8 (aryl-Cq), $131.4(\operatorname{aryl}-C H), 131.3$ (aryl-Cq), 129.7 (aryl-CH), $129.4(\operatorname{aryl}-C \mathrm{q}), 129.3(\operatorname{aryl}-C \mathrm{q}), 129.2(\operatorname{aryl}-C H), 128.6(\operatorname{aryl}-C \mathrm{q}), 128.5(\operatorname{aryl}-\mathrm{CH}), 128.3$ (aryl- $\mathrm{CH}), 128.2(\operatorname{aryl}-\mathrm{CH}), 128.1(\operatorname{aryl}-\mathrm{CH}), 127.7$ (aryl- $\mathrm{CH}), 127.6$ (aryl- $\mathrm{CH}), 127.3$ (arylCH), $126.6(\operatorname{aryl}-\mathrm{CH}), 125.7(\operatorname{aryl}-\mathrm{Cq}), 121.9$ (aryl- $\mathrm{CH}), 121.8(\operatorname{aryl}-\mathrm{CH}), 117.5$ (aryl-CH), 113.0 (aryl-Cq), $61.4\left(\mathrm{OCH}_{3}\right), 5.4\left(\mathrm{ZnN}(\mathrm{SiMe})_{2}\right)$. Anal. Calcd for $\mathrm{C}_{50} \mathrm{H}_{50} \mathrm{~N}_{2} \mathrm{O}_{2} \mathrm{Si}_{3} \mathrm{Zn}: \mathrm{C}$, 69.78; H, 5.86; N, 3.26. Found: C, 69.86; H, 5.91; N, 3.21. Yellow crystals of $2 \mathbf{c}$ suitable for X-ray diffraction analysis were prepared by prolonged crystallization from a toluene/hexane mixture (1:1) at room temperature.

Complex 2d. Using a procedure similar to that described above for 1a, compound 2d was obtained from proligand $\mathbf{d}(0.100 \mathrm{~g}, 0.170 \mathrm{mmol})$ and $\mathrm{Zn}\left[\mathrm{N}\left(\mathrm{SiMe}_{3}\right)_{2}\right]_{2}(0.072 \mathrm{~g}, 0.187$ mmol) and isolated as a yellow microcrystalline material $(0.099 \mathrm{~g}, 72 \%) .{ }^{1} \mathrm{H}$ NMR (500 $\left.\mathrm{MHz}, \mathrm{C}_{6} \mathrm{D}_{6}, 298 \mathrm{~K}\right): \delta 8.11(\mathrm{~s}, 1 \mathrm{H}, \operatorname{aryl}-\mathrm{CH}), 7.98\left(\mathrm{~d},{ }^{3} J_{H-H}=8.6,1 \mathrm{H}, \operatorname{aryl}-\mathrm{CH}\right), 7.94\left(\mathrm{~d},{ }^{3} J_{H-H}\right.$ $=5.5,6 \mathrm{H}$, aryl-CH $), 7.49\left(\mathrm{~d},{ }^{3} J_{H-H}=8.1,1 \mathrm{H}, \operatorname{aryl}-\mathrm{CH}\right), 7.35\left(\mathrm{~d},{ }^{3} J_{H-H}=7.9,1 \mathrm{H}\right.$, aryl-CH$)$, 7.25-7.23 (m, 10H, aryl-CH), 7.17 (s, 1H, aryl-CH), 7.01-6.97 (m, 2H, aryl-CH), 6.89-6.85 
(m, 2H, aryl-CH), $6.73\left(\mathrm{~d},{ }^{3} J_{H-H}=8.0,1 \mathrm{H}, \operatorname{aryl}-\mathrm{CH}\right), 6.56\left(\mathrm{~d},{ }^{3} J_{H-H}=7.5,1 \mathrm{H}\right.$, aryl-CH$), 3.04$ $\left(\mathrm{s}, 3 \mathrm{H}, \mathrm{OCH}_{3}\right),-0.04$ (s, 18H, ZnN(SiMe $\left.)_{2}\right) .{ }^{13} \mathrm{C} \mathrm{NMR}\left(125 \mathrm{MHz}, \mathrm{C}_{6} \mathrm{D}_{6}, 298 \mathrm{~K}\right): \delta 171.4$ (aryl-Cq), 157.9 (aryl-Cq), 155.4 (aryl-Cq), 152.5 (aryl-Cq), 144.9 (aryl- $C H$ ), 138.0 (arylCq), 137.1 (aryl- $C \mathrm{H}), 136.9$ (aryl-Cq), 136.3 (aryl-Cq), 131.8 (aryl-Cq), 131.5 (aryl- $C H$ ), 130.7 (aryl-CH), 129.9 (aryl- $C \mathrm{q}), 129.6$ (aryl- $C H), 129.1$ (aryl- $C H), 128.3$ (aryl-CH), 128.1 (aryl-Cq), $128.0(\operatorname{aryl}-C H), 127.9$ (aryl-Cq), 126.6 (aryl- $C H), 126.5$ (aryl-CH), 126.1 (aryl$C \mathrm{H}), 123.4(\operatorname{aryl}-\mathrm{CH}), 121.8(\operatorname{aryl}-\mathrm{CH}), 121.3(\operatorname{aryl}-\mathrm{CH}), 121.1$ (aryl- $\mathrm{CH}), 113.0$ (aryl-Cq), $61.5\left(\mathrm{OCH}_{3}\right), 5.49\left(\mathrm{ZnN}(\mathrm{SiMe})_{2}\right)$. Anal. Calcd for $\mathrm{C}_{46} \mathrm{H}_{48} \mathrm{~N}_{2} \mathrm{O}_{2} \mathrm{Si}_{3} \mathrm{Zn}: \mathrm{C}, 68.16 ; \mathrm{H}, 5.97 ; \mathrm{N}$, 3.46. Found: C, 68.09; H, 5.91; N, 3.52.

Complex 2e. Using a procedure similar to that described above for $\mathbf{1 a}$, compound $\mathbf{2 e}$ was obtained from proligand e $(0.100 \mathrm{~g}, 0.149 \mathrm{mmol})$ and $\mathrm{Zn}\left[\mathrm{N}\left(\mathrm{SiMe}_{3}\right)_{2}\right]_{2}(0.069 \mathrm{~g}, 0.178$ mmol) and isolated as a yellow microcrystalline solid (0.105 g, 79\%). ${ }^{1} \mathrm{H}$ NMR (500 MHz, $\left.\mathrm{C}_{6} \mathrm{D}_{6}, 298 \mathrm{~K}\right): \delta 8.08(\mathrm{~s}, 1 \mathrm{H}, \operatorname{aryl}-\mathrm{CH}), 8.04\left(\mathrm{~d},{ }^{3} J_{H-H}=8.2,1 \mathrm{H}, \operatorname{aryl}-\mathrm{CH}\right), 7.86-7.84(\mathrm{~m}, 6 \mathrm{H}$, $\operatorname{aryl}-\mathrm{CH}), 7.67(\mathrm{~s}, 1 \mathrm{H}, \mathrm{CH}=\mathrm{N}), 7.64\left(\mathrm{~d},{ }^{3} J_{H-H}=8.4,1 \mathrm{H}, \operatorname{aryl}-\mathrm{CH}\right), 7.32-7.28(\mathrm{~m}, 2 \mathrm{H}$, aryl$\mathrm{CH}$ ), 7.19-7.18 (m, 8H, aryl-CH), 7.07 (t, ${ }^{3} J_{H-H}=7.5,1 \mathrm{H}$, aryl-CH), 7.01-6.99 (m, 2H, aryl$\mathrm{CH}), 6.68\left(\mathrm{t},{ }^{3} J_{H-H}=7.8,1 \mathrm{H}\right.$, aryl-CH), $6.22\left(\mathrm{~d},{ }^{3} J_{H-H}=7.1,1 \mathrm{H}\right.$, aryl-CH), $3.15(\mathrm{br} \mathrm{s}, 3 \mathrm{H}$, $\left.\mathrm{CH}\left(\mathrm{CH}_{3}\right)_{2}\right), 2.95$ (br s, $\left.1 \mathrm{H}, \mathrm{CH}\left(\mathrm{CH}_{3}\right)_{2}\right), 1.39$ (br s, 3H, $\left.\mathrm{CH}\left(\mathrm{CH}_{3}\right)_{2}\right), 1.12$ (br s, 3H, $\left.\mathrm{CH}\left(\mathrm{CH}_{3}\right)_{2}\right)$, 1.04 (br s, 3H, $\left.\mathrm{CH}\left(\mathrm{CH}_{3}\right)_{2}\right), 0.87$ (br s, 3H, $\left.\mathrm{CH}\left(\mathrm{CH}_{3}\right)_{2}\right),-0.13$ (s, $\left.18 \mathrm{H}, \mathrm{ZnN}\left(\mathrm{SiMe}_{3}\right)_{2}\right) .{ }^{13} \mathrm{C}$ NMR (125 MHz, $\left.\mathrm{C}_{6} \mathrm{D}_{6}, 298 \mathrm{~K}\right): \delta 173.2$ (aryl-Cq), $162.5(C \mathrm{H}=\mathrm{N}), 157.7$ (aryl-Cq), 146.4 $(\operatorname{aryl}-C H), 143.9$ (aryl-Cq), 143.3 (aryl-Cq), 137.3 (aryl-CH), 136.7 (aryl-CH), 136.4 (arylCq), 134.8 (aryl-Cq), 132.2 (aryl-Cq), 130.9 (aryl- $C H$ ), 129.4 (aryl- $C H$ ), 128.8 (aryl-CH), $128.2(\operatorname{aryl}-C q), 127.9(\operatorname{aryl}-C H), 127.8(\operatorname{aryl}-C q), 127.7$ (aryl- $C H), 127.6(\operatorname{aryl}-C H), 127.5$ (aryl- $C H), 127.2$ (aryl-Cq), 122.5 (aryl- $C H), 121.8$ (aryl- $C H), 121.7$ (aryl- $C H), 112.8$ (aryl$C \mathrm{q}), \quad 28.9 \quad\left(\mathrm{CH}\left(\mathrm{CH}_{3}\right)_{2}\right), \quad 27.5 \quad\left(\mathrm{CH}\left(\mathrm{CH}_{3}\right)_{2}\right), \quad 26.1 \quad\left(\mathrm{CH}\left(\mathrm{CH}_{3}\right)_{2}\right), \quad 24.8 \quad\left(\mathrm{CH}\left(\mathrm{CH}_{3}\right)_{2}\right), \quad 23.8$ $\left(\mathrm{CH}\left(\mathrm{CH}_{3}\right)_{2}\right), 20.9\left(\mathrm{CH}\left(\mathrm{CH}_{3}\right)_{2}\right), 4.86\left(\mathrm{ZnN}(\mathrm{SiMe})_{2}\right)$. Anal. Calcd for $\mathrm{C}_{52} \mathrm{H}_{59} \mathrm{~N}_{3} \mathrm{OSi}_{3} \mathrm{Zn}: \mathrm{C}$, 70.04; H, 6.67; N, 4.71. Found: C, 69.92; H, 6.69; N, 4.79 . 
Complex 3c. Using a procedure similar to that described above for 1a, compound 3c was obtained from proligand $\mathbf{c}(0.100 \mathrm{~g}, 0.157 \mathrm{mmol})$ and $\mathrm{AlMe}_{3}(0.17 \mathrm{~mL}$ of a $1.0 \mathrm{M}$ solution in toluene, $0.17 \mathrm{mmol})$ and isolated as a yellow microcrystalline material $(0.096 \mathrm{~g}$, 88\%). ${ }^{1} \mathrm{H}$ NMR (500 MHz, $\left.\mathrm{C}_{6} \mathrm{D}_{6}, 298 \mathrm{~K}\right): \delta 8.31$ (s, 1H, aryl-CH), 7.92-7.90 (m, 6H, aryl$\mathrm{CH}), 7.51\left(\mathrm{~d},{ }^{3} J_{H-H}=8.3,2 \mathrm{H}, \operatorname{aryl}-\mathrm{CH}\right), 7.41\left(\mathrm{~d},{ }^{3} J_{H-H}=8.0,2 \mathrm{H}, \operatorname{aryl}-\mathrm{CH}\right), 7.23\left(\mathrm{q},{ }^{3} J_{H-H}=\right.$ 7.4, 2H, aryl-CH), 7.14-7.12 (m, 8H, aryl-CH), 7.09-7.06 (m, 4H, aryl-CH), $6.98\left(\mathrm{~d},{ }^{3} J_{H-H}=\right.$ 7.7, $1 \mathrm{H}$, aryl-CH), 6.85 (br s, $1 \mathrm{H}$, aryl-CH), $3.23\left(\mathrm{~s}, 3 \mathrm{H}, \mathrm{OCH}_{3}\right),-0.91\left(\mathrm{~s}, 3 \mathrm{H}, \mathrm{Al}\left(\mathrm{CH}_{3}\right)_{2}\right),-$ $1.33\left(\mathrm{~s}, 3 \mathrm{H}, \mathrm{Al}\left(\mathrm{CH}_{3}\right)_{2}\right) .{ }^{13} \mathrm{C} \mathrm{NMR}\left(125 \mathrm{MHz}, \mathrm{C}_{6} \mathrm{D}_{6}, 298 \mathrm{~K}\right): \delta 164.3$ (aryl- $\left.\mathrm{Cq}\right), 156.6$ (arylCq), 155.7 (aryl-Cq), 154.2 (aryl-Cq), 144.2 (aryl- $C H), 137.0$ (aryl- $C H), 136.9$ (aryl- $C H$ ), 136.7 (aryl-CH), 135.4 (aryl-Cq), 135.2 (aryl-Cq), 134.2 (aryl-Cq), 130.1 (aryl-Cq), 129.9 (aryl- $C H), 129.1(\operatorname{aryl}-C H), 129.0(\operatorname{aryl}-C q), 128.9$ (aryl- $C H), 128.3(\operatorname{aryl}-C H), 128.2$ (aryl$C \mathrm{H}), 128.1(\operatorname{aryl}-\mathrm{Cq}), 128.0(\operatorname{aryl}-\mathrm{CH}), 127.9$ (aryl-Cq), 127.8 (aryl-CH), 127.7 (aryl-CH), 127.6 (aryl-Cq), 127.5 (aryl- $C H), 127.2$ (aryl- $C H), 126.5$ (aryl- $C H), 125.3(\operatorname{aryl}-\mathrm{CH}), 124.7$ (aryl- $C \mathrm{H}), 122.5(\operatorname{aryl}-\mathrm{CH}), 114.7$ (aryl-Cq), $106.8(\operatorname{aryl}-\mathrm{CH}), 55.0\left(\mathrm{OCH}_{3}\right),-9.7\left(\mathrm{AlCH}_{3}\right)$, -11.3 $\left(\mathrm{AlCH}_{3}\right)$. Anal. Calcd for $\mathrm{C}_{46} \mathrm{H}_{38} \mathrm{AlNO}_{2} \mathrm{Si}: \mathrm{C}, 79.86 ; \mathrm{H}, 5.54 ; \mathrm{N}, 2.02$. Found: $\mathrm{C}$, 79.89; H, 5.56; N, 2.15. Yellow crystals of 3c suitable for X-ray analysis were obtained by prolonged crystallization from a THF/hexane mixture (1:1) at room temperature.

\section{Reaction of proligand e with AlMe 3 . Synthesis of Complex 3e' and Isolation of}

X-ray Suitable Crystals of 3e'” A Schlenk flask was charged with proligand e $(0.100 \mathrm{~g}$, $0.149 \mathrm{mmol})$ and toluene $(c a .10 \mathrm{~mL})$ was transferred in. $\mathrm{AlMe}_{3}(0.16 \mathrm{~mL}$ of a $1.0 \mathrm{M}$ solution in toluene, $0.165 \mathrm{mmol}$ ) was added to the reaction mixture at $-78{ }^{\circ} \mathrm{C}$. The reaction mixture was stirred at room temperature overnight. The solution was filtered and volatiles were evaporated under vacuum affording 3e' as a pale yellow microcrystalline powder $(0.098 \mathrm{~g}$, 91\%). ${ }^{1} \mathrm{H}$ NMR (500 MHz, $\left.\mathrm{C}_{6} \mathrm{D}_{6}, 298 \mathrm{~K}\right): \delta 8.19\left(\mathrm{~d},{ }^{3} \mathrm{~J}_{H-H}=8.8,1 \mathrm{H}\right.$, aryl-CH), $8.09(\mathrm{~s}, 1 \mathrm{H}$, aryl-CH), 7.83-7.79 (m, 6H, aryl-CH), $7.46\left(\mathrm{~d},{ }^{3} J_{H-H}=8.0,1 \mathrm{H}\right.$, aryl- $\left.\mathrm{CH}\right), 7.32-7.29(\mathrm{~m}, 2 \mathrm{H}$, aryl-CH), 7.17-7.01 (m, 10H, aryl-CH), $7.06\left(\mathrm{t},{ }^{3} J_{H-H}=8.0,3 \mathrm{H}\right.$, aryl-CH), $6.87\left(\mathrm{t},{ }^{3} J_{H-H}=\right.$ 
8.0, $1 \mathrm{H}$, aryl-CH), $6.44\left(\mathrm{~d},{ }^{3} J_{H-H}=7.8,1 \mathrm{H}\right.$, aryl-CH), $4.81\left(\mathrm{q},{ }^{3} J_{H-H}=6.0,1 \mathrm{H}, \mathrm{CHCH}_{3}\right), 3.70$ $\left(\mathrm{sept},{ }^{3} J_{H-H}=6.6,1 \mathrm{H}, \mathrm{CH}\left(\mathrm{CH}_{3}\right)_{2}\right), 3.40\left(\mathrm{sept},{ }^{3} J_{H-H}=6.6,1 \mathrm{H}, \mathrm{CH}\left(\mathrm{CH}_{3}\right)_{2}\right), 1.36\left(\mathrm{~d},{ }^{3} J_{H-H}=6.6\right.$, $\left.3 \mathrm{H}, \mathrm{CH}\left(\mathrm{CH}_{3}\right)_{2}\right), 1.21\left(\mathrm{~d},{ }^{3} J_{H-H}=6.6,3 \mathrm{H}, \mathrm{CH}\left(\mathrm{CH}_{3}\right)_{2}\right), 1.20\left(\mathrm{~d},{ }^{3} J_{H-H}=6.6,3 \mathrm{H}, \mathrm{CH}\left(\mathrm{CH}_{3}\right)_{2}\right)$, $1.03\left(\mathrm{~d},{ }^{3} J_{H-H}=6.0,3 \mathrm{H}, \mathrm{CHCH}_{3}\right), 0.58\left(\mathrm{~d},{ }^{3} \mathrm{~J}_{\mathrm{H}-\mathrm{H}}=6.6,3 \mathrm{H}, \mathrm{CH}\left(\mathrm{CH}_{3}\right)_{2}\right),-0.85\left(\mathrm{~s}, 3 \mathrm{H}, \mathrm{AlCH}_{3}\right)$. ${ }^{13} \mathrm{C}$ NMR (125 MHz, $\left.\mathrm{C}_{6} \mathrm{D}_{6}, 298 \mathrm{~K}\right): \delta 165.4$ (aryl-Cq), 163.9 (aryl-Cq), 152.7 (aryl-Cq), 148.5 (aryl-Cq), $146.6(\operatorname{aryl}-C q), 145.3(\operatorname{aryl}-C H), 142.3(\operatorname{aryl}-C q), 139.2$ (aryl-CH), 136.7 (aryl$C H), 136.6$ (aryl-CH), 135.4 (aryl-Cq), 133.5 (aryl-Cq), 131.0 (aryl-Cq), 129.7 (aryl-CH), 129.1 (aryl- $C H$ ), 128.8 (aryl- $C \mathrm{q}), 127.7$ (aryl- $C \mathrm{H}), 127.6$ (aryl- $\mathrm{CH}), 124.4$ (aryl- $\mathrm{CH}), 124.1$ (aryl- $\mathrm{CH}), 123.4(\operatorname{aryl}-\mathrm{CH}), 123.0(\operatorname{aryl}-\mathrm{CH}), 122.7$ (aryl- $\mathrm{CH}), 118.0(\operatorname{aryl}-\mathrm{CH}), 114.9$ (arylCq), $61.2\left(\mathrm{CHCH}_{3}\right), 27.9\left(\mathrm{CH}\left(\mathrm{CH}_{3}\right)_{2}\right), 27.3\left(\mathrm{CH}\left(\mathrm{CH}_{3}\right)_{2}\right), 26.7\left(\mathrm{CH}\left(\mathrm{CH}_{3}\right)_{2}\right), 25.3\left(\mathrm{CH}\left(\mathrm{CH}_{3}\right)_{2}\right)$, $25.0\left(\mathrm{CH}\left(\mathrm{CH}_{3}\right)_{2}\right), 22.5\left(\mathrm{CH}\left(\mathrm{CH}_{3}\right)_{2}\right), 21.8\left(\mathrm{CHCH}_{3}\right),-14.2\left(\mathrm{AlCH}_{3}\right)$. Anal. Calcd for $\mathrm{C}_{48} \mathrm{H}_{47} \mathrm{AlN}_{2} \mathrm{OSi}: \mathrm{C}, 79.74 ; \mathrm{H}, 6.55 ; \mathrm{N}, 3.87$. Found: $\mathrm{C}, 79.81 ; \mathrm{H}, 6.50 ; \mathrm{N}, 3.80$. Recrystallization of $\mathbf{3} \mathbf{e}^{\prime}$ from a solution in a toluene/hexanes mixture at room temperature resulted in isolation of crystals of partial hydrolysis product 3e",

Complex 4e. A Schlenk flask was charged with proligand e $(0.100 \mathrm{~g}, 0.149 \mathrm{mmol})$ and $\mathrm{Y}\left[\mathrm{N}\left(\mathrm{SiHMe}_{2}\right)_{2}\right]_{3} \mathrm{THF}(0.084 \mathrm{~g}, 0.149 \mathrm{mmol})$, and toluene $(c a .10 \mathrm{~mL})$ was vacuum transferred in. The reaction mixture was stirred for $12 \mathrm{~h}$ at room temperature, then filtered and evaporated under vacuum. The solid residue was washed with pentane $(10 \mathrm{~mL})$ and dried under vacuum to give $4 \mathbf{e}$ as a red microcrystalline material $(0.133 \mathrm{~g}, 87 \%) .{ }^{1} \mathrm{H}$ NMR (500 MHz, $\left.\mathrm{C}_{6} \mathrm{D}_{6}, 333 \mathrm{~K}\right): \delta 8.08(\mathrm{~s}, 1 \mathrm{H}, \operatorname{aryl}-\mathrm{CH}), 7.99(\mathrm{~s}, 1 \mathrm{H}, \mathrm{CH}=\mathrm{N}), 7.91-7.90(\mathrm{~m}, 6 \mathrm{H}$, aryl$\mathrm{CH}), 7.79\left(\mathrm{~d},{ }^{3} J_{H-H}=7.7,1 \mathrm{H}, \operatorname{aryl}-\mathrm{CH}\right), 7.36\left(\mathrm{~d},{ }^{3} J_{H-H}=8.0,1 \mathrm{H}\right.$, aryl-CH$), 7.25-7.24(\mathrm{~m}$, $10 \mathrm{H}$, aryl-CH), $7.12(\mathrm{~s}, 2 \mathrm{H}$, aryl- $\mathrm{CH}), 7.01-6.99\left(\mathrm{~m}, 2 \mathrm{H}\right.$, aryl-CH), $6.89\left(\mathrm{t},{ }^{3} \mathrm{~J}_{H-H}=7.7,1 \mathrm{H}\right.$, $\operatorname{aryl-CH}), 6.53\left(\mathrm{~d},{ }^{3} J_{H-H}=6.2,1 \mathrm{H}, \operatorname{aryl}-\mathrm{CH}\right), 4.67\left(\right.$ br s, $\left.4 \mathrm{H}, \mathrm{N}\left(\mathrm{SiHMe}_{2}\right)_{2}\right), 3.16($ br s, $2 \mathrm{H}$, $\left.\mathrm{CH}\left(\mathrm{CH}_{3}\right)_{2}\right), 1.39\left(\mathrm{~d},{ }^{3} \mathrm{~J}_{H-H}=5.2,6 \mathrm{H}, \mathrm{CH}\left(\mathrm{CH}_{3}\right)_{2}\right), 1.04\left(\mathrm{~d},{ }^{3} J_{H-H}=5.2,6 \mathrm{H}, \mathrm{CH}\left(\mathrm{CH}_{3}\right)_{2}\right),-0.09$ (s, 12H, N(SiHMe $\left.)_{2}\right),-0.16$ (s, 12H, N(SiHMe $\left.)_{2}\right) .{ }^{13} \mathrm{C} \mathrm{NMR}\left(125 \mathrm{MHz}, \mathrm{C}_{6} \mathrm{D}_{6}, 333 \mathrm{~K}\right): \delta$ $171.2(\mathrm{CH} H \mathrm{~N}), 168.9(\operatorname{aryl}-C \mathrm{q}), 159.1(\operatorname{aryl}-C \mathrm{q}), 147.8(\operatorname{aryl}-C \mathrm{q}), 147.3(\operatorname{aryl}-C \mathrm{q}), 146.4$ 
(aryl-CH), $140.3(\operatorname{aryl}-C q), 136.9$ (aryl- $C H), 136.7$ (aryl-CH), 136.2 (aryl-Cq), 135.1 (arylCq), 133.1 (aryl- $C H), 129.3(\operatorname{aryl}-C H), 128.9$ (aryl-CH), 128.8 (aryl-Cq), 127.9 (aryl-CH), 127.6 (aryl- $C H), 127.1$ (aryl- $C H), 125.2$ (aryl-Cq), 124.6 (aryl- $C H), 124.1$ (aryl- $C H), 123.3$ (aryl- $\mathrm{CH}), \quad 121.9$ (aryl- $\mathrm{CH}), \quad 114.9$ (aryl-Cq), $28.5\left(\mathrm{CH}\left(\mathrm{CH}_{3}\right)_{2}\right), 26.2 \quad\left(\mathrm{CH}\left(\mathrm{CH}_{3}\right)_{2}\right), 2.8$ $\left(\mathrm{N}(\mathrm{SiHMe})_{2}\right), 2.2\left(\mathrm{~N}\left(\mathrm{SiH} M e_{2}\right)_{2}\right) .{ }^{29} \mathrm{Si}\left\{{ }^{1} \mathrm{H}\right\} \mathrm{NMR}\left(79 \mathrm{MHz}, \mathrm{C}_{6} \mathrm{D}_{6}, 333 \mathrm{~K}\right): \delta-11.5(\mathrm{~s}, 1 \mathrm{Si}$, $\mathrm{Ph}_{3} \mathrm{Si}$ ), -22.7 (br s, 2Si, $\mathrm{SiHMe}_{2}$ ), -22.8 (br s, 2Si, SiHMe $) .{ }^{29} \mathrm{Si} \mathrm{NMR}\left(79 \mathrm{MHz}, \mathrm{C}_{6} \mathrm{D}_{6}, 333\right.$ $\mathrm{K}): \delta-22.7\left(\mathrm{~d} \mathrm{sept},{ }^{1} J_{\mathrm{Si}-\mathrm{H}}=165,{ }^{2} J_{\mathrm{Si}-\mathrm{H}}=6.8,2 \mathrm{Si}\right),-22.8\left(\mathrm{~d} \mathrm{sept},{ }^{1} J_{\mathrm{Si}-\mathrm{H}}=165,{ }^{2} J_{\mathrm{Si}-\mathrm{H}}=6.8,2 \mathrm{Si}\right)$. Anal. Calcd for $\mathrm{C}_{54} \mathrm{H}_{69} \mathrm{~N}_{4} \mathrm{OSi}_{5} \mathrm{Y}$ : C, 63.62; H, 6.82; N, 5.50. Found: C, 63.70; H, 6.89; N, 5.60 .

Complex 4f. Using a procedure similar to that described above for $\mathbf{4 e}$, compound $\mathbf{4 f}$ was obtained from proligand $\mathbf{f}(0.050 \mathrm{~g}, 0.067 \mathrm{mmol})$ and $\mathrm{Sc}\left[\mathrm{N}\left(\mathrm{SiHMe}_{2}\right)_{2}\right]_{3} \mathrm{THF}(0.0345 \mathrm{~g}$, $0.067 \mathrm{mmol})$. Compound $\mathbf{4 f}$ was isolated as an orange microcrystalline material (0.045 g, 67\%). ${ }^{1} \mathrm{H}$ NMR $\left(500 \mathrm{MHz}, \mathrm{C}_{6} \mathrm{D}_{6}, 298 \mathrm{~K}\right): \delta 8.26\left(\mathrm{~d},{ }^{3} \mathrm{~J}_{H-H}=8.5,1 \mathrm{H}\right.$, aryl-CH), $8.01(\mathrm{~s}, 1 \mathrm{H}$, $\operatorname{aryl}-\mathrm{CH}), 7.87-7.85(\mathrm{~m}, 2 \mathrm{H}, \operatorname{aryl}-\mathrm{CH}), 7.81-7.79(\mathrm{~m}, 6 \mathrm{H}, \operatorname{aryl}-\mathrm{CH}), 7.63\left(\mathrm{~d},{ }^{3} J_{H-H}=7.2,2 \mathrm{H}\right.$, $\operatorname{aryl}-\mathrm{CH}), 7.53\left(\mathrm{~d},{ }^{3} J_{H-H}=7.9,1 \mathrm{H}, \operatorname{aryl}-\mathrm{CH}\right), 7.45\left(\mathrm{~d},{ }^{3} J_{H-H}=7.5,1 \mathrm{H}, \operatorname{aryl}-\mathrm{C} H\right), 7.34\left(\mathrm{~d},{ }^{3} J_{H-H}\right.$ $=8.0,2 \mathrm{H}$, aryl- $\mathrm{CH}), 7.19-7.15(\mathrm{~m}, 9 \mathrm{H}$, aryl-CH$), 7.03-7.00(\mathrm{~m}, 4 \mathrm{H}, \operatorname{aryl}-\mathrm{CH}), 6.83\left(\mathrm{t},{ }^{3} J_{H-H}=\right.$ $7.8,1 \mathrm{H}$, aryl-CH), $6.55\left(\mathrm{~d},{ }^{3} J_{H-H}=7.6,1 \mathrm{H}\right.$, aryl- $\left.\mathrm{CH}\right), 5.58(\mathrm{~s}, 1 \mathrm{H}, \mathrm{CHPh}), 4.84\left(\mathrm{sept},{ }^{3} J_{H-H}=\right.$ 3.0, $\left.2 \mathrm{H}, \mathrm{N}\left(\mathrm{SiH} \mathrm{Me}_{2}\right)_{2}\right), 3.85$ (sept, $\left.{ }^{3} J_{H-H}=6.8,1 \mathrm{H}, \mathrm{CH}\left(\mathrm{CH}_{3}\right)_{2}\right), 3.17-3.14\left(\mathrm{~m}, 3 \mathrm{H}, \alpha-\mathrm{CH}_{2}\right.$, $\left.\mathrm{THF}+\mathrm{CH}\left(\mathrm{CH}_{3}\right)_{2}\right), 3.01-2.99\left(\mathrm{~m}, 2 \mathrm{H}, \alpha-\mathrm{CH}_{2}, \mathrm{THF}\right), 1.47\left(\mathrm{~d},{ }^{3} J_{H-H}=6.8,3 \mathrm{H}, \mathrm{CH}\left(\mathrm{CH}_{3}\right)_{2}\right)$, $1.22\left(\mathrm{~d},{ }^{3} J_{H-H}=6.8,3 \mathrm{H}, \mathrm{CH}\left(\mathrm{CH}_{3}\right)_{2}\right), 1.01\left(\mathrm{~d},{ }^{3} J_{H-H}=6.8,3 \mathrm{H}, \mathrm{CH}\left(\mathrm{CH}_{3}\right)_{2}\right), 0.71-0.67(\mathrm{~m}, 4 \mathrm{H}$, $\left.\beta-\mathrm{CH}_{2} \mathrm{THF}\right), 0.43\left(\mathrm{~d},{ }^{3} J_{H-H}=6.8,3 \mathrm{H}, \mathrm{CH}\left(\mathrm{CH}_{3}\right)_{2}\right), 0.07\left(\mathrm{~d},{ }^{3} J_{H-H}=3.0,6 \mathrm{H}, \mathrm{N}\left(\mathrm{SiH} M e_{2}\right)_{2}\right), 0.05$ $\left(\mathrm{d},{ }^{3} J_{H-H}=3.0,6 \mathrm{H}, \mathrm{N}(\mathrm{SiHMe})_{2}\right) .{ }^{13} \mathrm{C} \mathrm{NMR}\left(125 \mathrm{MHz}, \mathrm{C}_{6} \mathrm{D}_{6}, 298 \mathrm{~K}\right): \delta 166.6$ (aryl-Cq), 165.3 (aryl-Cq), 154.1 (aryl-Cq), 151.6 (aryl-Cq), 147.0 (aryl-Cq), 146.1 (aryl-Cq), 145.5 (aryl-Cq), 145.3 (aryl-CH), 141.4 (aryl-Cq), 141.1 (aryl-Cq),136.8 (aryl-CH), 136.6 (arylCH), 136.5 (aryl- $C H), 135.1$ (aryl- $C q), 129.8$ (aryl- $C H$ ), 129.1 (aryl- $C H$ ), 128.7 (aryl- $C H$ ), 128.3 (aryl- $C \mathrm{q}), 128.1$ (aryl- $\mathrm{CH}), 127.7$ (aryl- $\mathrm{CH}), 127.6$ (aryl- $\mathrm{CH}), 127.2$ (aryl- $\mathrm{CH}), 127.1$ 
$(\operatorname{aryl}-\mathrm{CH}), 127.0(\operatorname{aryl}-\mathrm{CH}), 126.9(\operatorname{aryl}-\mathrm{CH}), 126.4(\operatorname{aryl}-\mathrm{Cq}), 125.9(\operatorname{aryl}-\mathrm{Cq}), 125.0$ (aryl$\mathrm{CH}), 124.4$ (aryl- $\mathrm{CH}), 123.9$ (aryl- $\mathrm{CH}), 123.7$ (aryl- $\mathrm{CH}), 123.5$ (aryl- $\mathrm{CH}), 121.9$ (aryl- $\mathrm{CH})$, 119.3 (aryl- $C H$ ), 117.3 (aryl- $C q), 79.2(\mathrm{CHPh}), 71.7\left(\alpha-\mathrm{CH}_{2}, \mathrm{THF}\right), 27.5\left(\mathrm{CH}\left(\mathrm{CH}_{3}\right)_{2}\right), 27.1$ $\left(\mathrm{CH}\left(\mathrm{CH}_{3}\right)_{2}\right), 26.9\left(\mathrm{CH}\left(\mathrm{CH}_{3}\right)_{2}\right), 25.2\left(\mathrm{CH}\left(\mathrm{CH}_{3}\right)_{2}\right), 25.1\left(\mathrm{CH}\left(\mathrm{CH}_{3}\right)_{2}\right), 25.0\left(\mathrm{CH}\left(\mathrm{CH}_{3}\right)_{2}\right), 24.3(\beta-$ $\left.\mathrm{CH}_{2}, \mathrm{THF}\right), 3.1\left(\mathrm{~N}(\mathrm{SiHMe})_{2}\right), 3.0\left(\mathrm{~N}(\mathrm{SiHMe})_{2}\right) .{ }^{29} \mathrm{Si}\left\{{ }^{1} \mathrm{H}\right\} \mathrm{NMR}\left(79 \mathrm{MHz}, \mathrm{C}_{6} \mathrm{D}_{6}, 298 \mathrm{~K}\right)$ (the signal from the $\mathrm{Ph}_{3} \mathrm{Si}$ group was not observed): $\delta-21.4$ (s, 2Si). ${ }^{29} \mathrm{Si} \mathrm{NMR}(79 \mathrm{MHz}$, $\left.\mathrm{C}_{6} \mathrm{D}_{6}, 298 \mathrm{~K}\right): \delta-21.3\left(\mathrm{~d} \mathrm{~m},{ }^{1} J_{\mathrm{Si}-\mathrm{H}}=180,2 \mathrm{Si}\right)$. Anal. Calcd for $\mathrm{C}_{60} \mathrm{H}_{67} \mathrm{~N}_{3} \mathrm{O}_{2} \mathrm{Si} \mathrm{Si}_{3} \mathrm{Sc}: \mathrm{C}, 72.69$; H, 6.81; N, 4.24. Found: C, 72.61; H, 6.89; N, 4.30.

Complex 5f. A Schlenk flask was charged with proligand f $(0.100 \mathrm{~g}, 0.134 \mathrm{mmol})$ and $\mathrm{Y}\left[\mathrm{N}\left(\mathrm{SiHMe}_{2}\right)_{2}\right]_{3} \mathrm{THF}(0.075 \mathrm{~g}, 0.134 \mathrm{mmol})$, and toluene $(c a .10 \mathrm{~mL})$ was vacuum transferred in. The reaction mixture was stirred $12 \mathrm{~h}$ at $50{ }^{\circ} \mathrm{C}$, then filtered and evaporated under vacuum. The residue was washed with pentane $(10 \mathrm{~mL})$ and dried under vacuum to give $\mathbf{5 f}$ as an orange microcrystalline material $(0.110 \mathrm{~g}, 81 \%) .{ }^{1} \mathrm{H}$ NMR $(400 \mathrm{MHz}$, toluene$\left.d_{8}, 298 \mathrm{~K}\right): \delta 8.09\left(\mathrm{~d},{ }^{3} J_{H-H}=8.6,1 \mathrm{H}\right.$, aryl-CH $), 7.93(\mathrm{~s}, 1 \mathrm{H}, \operatorname{aryl}-\mathrm{CH}), 7.83-7.81(\mathrm{~m}, 6 \mathrm{H}$, $\operatorname{aryl}-\mathrm{CH}), 7.70\left(\mathrm{~d},{ }^{3} J_{H-H}=7.1,2 \mathrm{H}\right.$, aryl-CH$), 7.45-7.40(\mathrm{~m}, 2 \mathrm{H}, \operatorname{aryl}-\mathrm{CH}), 7.35\left(\mathrm{~d},{ }^{3} J_{H-H}=8.0\right.$, 1H, aryl-CH), 7.28-7.24 (m, 3H, aryl- $\mathrm{CH}), 7.23-7.21(\mathrm{~m}, 7 \mathrm{H}$, aryl-CH), 7.13-6.91 (m, 6H, $\operatorname{aryl-CH}), 6.71\left(\mathrm{~d},{ }^{3} J_{H-H}=7.1,1 \mathrm{H}, \operatorname{aryl}-\mathrm{CH}\right), 5.34(\mathrm{~s}, 1 \mathrm{H}, \mathrm{CHPh}), 4.70\left(\mathrm{sept},{ }^{3} J_{H-H}=3.0,2 \mathrm{H}\right.$, $\left.\mathrm{N}\left(\mathrm{Si} H \mathrm{Me}_{2}\right)_{2}\right), 3.77\left(\mathrm{sept},{ }^{3} J_{H-H}=6.8,1 \mathrm{H}, \mathrm{CH}\left(\mathrm{CH}_{3}\right)_{2}\right), 3.12\left(\mathrm{sept},{ }^{3} \mathrm{~J}_{H-H}=6.8,1 \mathrm{H}, \mathrm{CH}\left(\mathrm{CH}_{3}\right)_{2}\right)$, $2.87-2.83\left(\mathrm{~m}, 2 \mathrm{H}, \alpha-\mathrm{CH}_{2}, \mathrm{THF}\right), 2.75-2.71\left(\mathrm{~m}, 2 \mathrm{H}, \alpha-\mathrm{CH}_{2}, \mathrm{THF}\right), 1.42\left(\mathrm{~d},{ }^{3} J_{H-H}=6.8,3 \mathrm{H}\right.$, $\left.\mathrm{CH}\left(\mathrm{CH}_{3}\right)_{2}\right), 1.18\left(\mathrm{~d},{ }^{3} J_{H-H}=6.8,3 \mathrm{H}, \mathrm{CH}\left(\mathrm{CH}_{3}\right)_{2}\right), 1.02\left(\mathrm{~d},{ }^{3} J_{H-H}=6.8,3 \mathrm{H}, \mathrm{CH}\left(\mathrm{CH}_{3}\right)_{2}\right)$, $0.74-0.71\left(\mathrm{~m}, 4 \mathrm{H}, \beta-\mathrm{CH}_{2}, \mathrm{THF}\right), 0.49\left(\mathrm{~d},{ }^{3} J_{H-H}=6.8,3 \mathrm{H}, \mathrm{CH}\left(\mathrm{CH}_{3}\right)_{2}\right), 0.18\left(\mathrm{~d},{ }^{3} J_{H-H}=3.0\right.$, $\left.6 \mathrm{H}, \mathrm{N}\left(\mathrm{SiH} M e_{2}\right)_{2}\right), 0.11\left(\mathrm{~d},{ }^{3} J_{H-H}=3.0,6 \mathrm{H}, \mathrm{N}\left(\mathrm{SiH} M e_{2}\right)_{2}\right) .{ }^{13} \mathrm{C}$ NMR $\left(100 \mathrm{MHz}\right.$, toluene- $d_{8}$, $298 \mathrm{~K}): \delta 168.0(\operatorname{aryl}-C q), 164.8(\operatorname{aryl}-C q), 155.8$ (aryl-Cq), 152.5 (aryl-Cq), 147.8 (aryl-Cq), 147.2 (aryl- $C \mathrm{q}), 146.6$ (aryl-Cq), 145.2 (aryl- $C \mathrm{H}), 137.3$ (aryl- $C \mathrm{q}), 136.9$ (aryl- $C \mathrm{H}), 136.7$ (aryl-CH), $136.4(\operatorname{aryl}-C q), 129.3(\operatorname{aryl}-\mathrm{CH}), 129.2(\operatorname{aryl}-\mathrm{CH}), 129.1$ (aryl- $\mathrm{CH}), 128.9$ (aryl$C \mathrm{H}), 128.5$ (aryl- $\mathrm{CH}), 128.0$ (aryl- $\mathrm{CH}), 127.7$ (aryl- $C \mathrm{q}), 127.4$ (aryl-CH), 127.2 (aryl- $\mathrm{CH})$, 
$127.0(\operatorname{aryl}-\mathrm{CH}), 126.2(\operatorname{aryl}-\mathrm{CH}), 125.3(\operatorname{aryl}-\mathrm{Cq}), 124.9(\operatorname{aryl}-\mathrm{CH}), 124.3(\operatorname{aryl}-\mathrm{CH}), 123.7$ (aryl- $\mathrm{CH}), 123.0(\operatorname{aryl}-\mathrm{CH}), 121.9(\operatorname{aryl}-\mathrm{CH}), 119.8(\operatorname{aryl}-\mathrm{CH}), 117.8(\operatorname{aryl}-\mathrm{Cq}), 81.0(\mathrm{CHPh})$, $70.8\left(\alpha-\mathrm{CH}_{2}\right.$, THF), $27.9\left(\mathrm{CH}\left(\mathrm{CH}_{3}\right)_{2}\right), 27.5\left(\mathrm{CH}\left(\mathrm{CH}_{3}\right)_{2}\right), 26.6\left(\mathrm{CH}\left(\mathrm{CH}_{3}\right)_{2}\right), 25.8\left(\mathrm{CH}\left(\mathrm{CH}_{3}\right)_{2}\right)$, $25.6\left(\mathrm{CH}\left(\mathrm{CH}_{3}\right)_{2}\right), 25.0\left(\mathrm{CH}\left(\mathrm{CH}_{3}\right)_{2}\right), 24.7\left(\beta-\mathrm{CH}_{2}, \mathrm{THF}\right), 3.7\left(\mathrm{~N}(\mathrm{SiHMe})_{2}\right), 3.3\left(\mathrm{~N}(\mathrm{SiHMe})_{2}\right)$. ${ }^{29} \mathrm{Si}\left\{{ }^{1} \mathrm{H}\right\}$ NMR (79 MHz, toluene- $\left.d_{8}, 298 \mathrm{~K}\right): \delta-11.8$ (s, $\left.1 \mathrm{Si}, \mathrm{Ph}_{3} \mathrm{Si}\right),-21.9$ (s, 2Si, SiHMe $)$. ${ }^{29} \mathrm{Si}$ NMR (79 MHz, toluene- $\left.d_{8}, 298 \mathrm{~K}\right): \delta-21.9\left(\mathrm{~d} \mathrm{~m},{ }^{1} J_{\mathrm{Si}-\mathrm{H}}=165,2 \mathrm{Si}\right)$. Anal. Calcd for $\mathrm{C}_{60} \mathrm{H}_{67} \mathrm{~N}_{3} \mathrm{O}_{2} \mathrm{Si}_{3} \mathrm{Y}: \mathrm{C}, 69.60 ; \mathrm{H}, 6.52 ; \mathrm{N}, 4.06$. Found: $\mathrm{C}, 69.85 ; \mathrm{H}, 6.57 ; \mathrm{N}, 4.11$

Complex 6f. Using a procedure similar to that described above for $\mathbf{5 f}$, compound $\mathbf{6 f}$ was obtained from proligand $\mathbf{f}(0.100 \mathrm{~g}, 0.134 \mathrm{mmol})$ and $\mathrm{La}\left[\mathrm{N}\left(\mathrm{SiHMe}_{2}\right)_{2}\right]_{3}(\mathrm{THF})_{2}(0.091 \mathrm{~g}$, $0.134 \mathrm{mmol})$. Compound $\mathbf{6 f}$ was isolated as an orange microcrystalline material $(0.120 \mathrm{~g}$, 83\%). ${ }^{1} \mathrm{H}$ NMR (500 MHz, $\left.\mathrm{C}_{6} \mathrm{D}_{6}, 298 \mathrm{~K}\right): \delta 7.99(\mathrm{~s}, 1 \mathrm{H}$, aryl-CH), 7.84-7.82 (m, 6H, aryl$\mathrm{CH}), 7.74\left(\mathrm{~d},{ }^{3} J_{H-H}=7.1,1 \mathrm{H}\right.$, aryl-CH$), 7.46-7.44(\mathrm{~m}, 1 \mathrm{H}, \operatorname{aryl}-\mathrm{C} H), 7.35\left(\mathrm{~d},{ }^{3} J_{H-H}=8.1,1 \mathrm{H}\right.$, aryl-CH), $7.32\left(\mathrm{~d},{ }^{3} J_{H-H}=8.1,1 \mathrm{H}\right.$, aryl-CH$), 7.27\left(\mathrm{t},{ }^{3} J_{H-H}=7.6 \mathrm{~Hz}, 3 \mathrm{H}\right.$, aryl-CH $), 7.20-7.15$ $(\mathrm{m}, 9 \mathrm{H}, \operatorname{aryl}-\mathrm{CH}), 7.07-7.01(\mathrm{~m}, 5 \mathrm{H}, \operatorname{aryl}-\mathrm{CH}), 6.96-6.93(\mathrm{~m}, 1 \mathrm{H}, \operatorname{aryl}-\mathrm{CH}), 6.86\left(\mathrm{t},{ }^{3} J_{H-H}=\right.$ 7.6, $1 \mathrm{H}$, aryl-CH), $6.69\left(\mathrm{~d},{ }^{3} J_{H-H}=7.6,1 \mathrm{H}, \operatorname{aryl}-\mathrm{CH}\right), 5.40(\mathrm{~s}, 1 \mathrm{H}, \mathrm{CHPh}), 4.78(\mathrm{br} \mathrm{s}, 2 \mathrm{H}$, $\left.\mathrm{N}\left(\mathrm{Si} H \mathrm{Me}_{2}\right)_{2}\right), 3.77\left(\mathrm{sept},{ }^{3} J_{H-H}=6.5,1 \mathrm{H}, \mathrm{CH}\left(\mathrm{CH}_{3}\right)_{2}\right), 3.03\left(\mathrm{sept},{ }^{3} J_{H-H}=6.5,1 \mathrm{H}, \mathrm{CH}\left(\mathrm{CH}_{3}\right)_{2}\right)$, 2.67 (br s, $\left.4 \mathrm{H}, \alpha-\mathrm{CH}_{2}, \mathrm{THF}\right), 1.31\left(\mathrm{~d},{ }^{3} J_{H-H}=6.5,3 \mathrm{H}, \mathrm{CH}\left(\mathrm{CH}_{3}\right)_{2}\right), 1.21\left(\mathrm{~d},{ }^{3} J_{H-H}=6.5,3 \mathrm{H}\right.$, $\left.\mathrm{CH}\left(\mathrm{CH}_{3}\right)_{2}\right), 0.93\left(\mathrm{~d},{ }^{3} J_{H-H}=6.5,3 \mathrm{H}, \mathrm{CH}\left(\mathrm{CH}_{3}\right)_{2}\right), 0.83$ (br s, $\left.4 \mathrm{H}, \beta-\mathrm{CH}_{2}, \mathrm{THF}\right), 0.55\left(\mathrm{~d},{ }^{3} J_{H-H}=\right.$ 6.5, 3H, CH(CH$\left.)_{2}\right), 0.13\left(\mathrm{~d},{ }^{3} J_{H-H}=3.0,6 \mathrm{H}, \mathrm{N}(\mathrm{SiHMe})_{2}\right), 0.11\left(\mathrm{~d},{ }^{3} J_{H-H}=3.0,6 \mathrm{H}\right.$, $\left.\mathrm{N}(\mathrm{SiHMe})_{2}\right) .{ }^{13} \mathrm{C} \mathrm{NMR}\left(125 \mathrm{MHz}, \mathrm{C}_{6} \mathrm{D}_{6}, 298 \mathrm{~K}\right): \delta 168.4$ (aryl-Cq), 162.8 (aryl-Cq), 155.2 (aryl-Cq), 148.6 (aryl-Cq), 148.4 (aryl-Cq), 147.8 (aryl-Cq), 147.2 (aryl-Cq), 144.4 (aryl$C H), 141.4$ (aryl-Cq), 141.1 (aryl-Cq), 137.1 (aryl-Cq), 136.5 (aryl- $C H$ ), 129.0 (aryl-CH), 128.9 (aryl- $C q), 128.8$ (aryl- $C H), 128.7$ (aryl- $C H), 128.5$ (aryl- $C H), 128.4$ (aryl-CH), 128.3 (aryl- $\mathrm{CH}), 127.8$ (aryl- $\mathrm{CH}), 127.2(\operatorname{aryl}-\mathrm{CH}), 127.1$ (aryl- $\mathrm{CH}), 126.9$ (aryl- $\mathrm{CH}), 126.6$ (aryl$\mathrm{CH}), 124.5(\operatorname{aryl}-\mathrm{CH}), 124.3(\operatorname{aryl}-\mathrm{CH}), 123.5(\operatorname{aryl}-\mathrm{CH}), 122.9$ (aryl- $\mathrm{CH}), 121.5$ (aryl- $\mathrm{CH})$, 119.6 (aryl- $\mathrm{CH}), 117.9$ (aryl-Cq), $81.9(\mathrm{CHPh}), 68.9\left(\alpha-\mathrm{CH}_{2}, \mathrm{THF}\right), 27.5\left(\mathrm{CH}\left(\mathrm{CH}_{3}\right)_{2}\right), 27.4$ 
$\left(\mathrm{CH}\left(\mathrm{CH}_{3}\right)_{2}\right), 26.1\left(\mathrm{CH}\left(\mathrm{CH}_{3}\right)_{2}\right), 25.7\left(\mathrm{CH}\left(\mathrm{CH}_{3}\right)_{2}\right), 25.6\left(\mathrm{CH}\left(\mathrm{CH}_{3}\right)_{2}\right), 24.6\left(\beta-C \mathrm{H}_{2}, \mathrm{THF}\right), 3.1$ $\left(\mathrm{N}(\mathrm{SiHMe})_{2}\right), 0.2\left(\mathrm{~N}\left(\mathrm{SiHM} e_{2}\right)_{2}\right) .{ }^{29} \mathrm{Si}\left\{{ }^{1} \mathrm{H}\right\} \mathrm{NMR}\left(79 \mathrm{MHz}, \mathrm{C}_{6} \mathrm{D}_{6}, 298 \mathrm{~K}\right): \delta-11.5(\mathrm{~s}, 1 \mathrm{Si}$, $\left.\mathrm{Ph}_{3} \mathrm{Si}\right),-24.7$ (s, 2Si, SiHMe $)$. ${ }^{29} \mathrm{Si}$ NMR $\left(79 \mathrm{MHz}, \mathrm{C}_{6} \mathrm{D}_{6}, 298 \mathrm{~K}\right): \delta-24.7\left(\mathrm{~d}\right.$ sept,${ }^{1} J_{\mathrm{Si}-\mathrm{H}}=$ $163,{ }^{2} J_{\mathrm{Si}-\mathrm{H}}=6.6,2 \mathrm{Si}$ ). Anal. Calcd for $\mathrm{C}_{60} \mathrm{H}_{67} \mathrm{~N}_{3} \mathrm{O}_{2} \mathrm{Si} \mathrm{Si}_{3} \mathrm{La}: \mathrm{C}, 66.40 ; \mathrm{H}, 6.22 ; \mathrm{N}, 3.87$. Found: C, 66.49; H, 6.19; N, 3.92 .

General Procedure for Polymerization of rac-Lactide. In a typical experiment (Table 1, entry 5), in a glovebox, a Schlenk flask was charged with a solution of complex 1c $(10.0 \mathrm{mg}, 13.7 \mu \mathrm{mol})$ in toluene $(1.0 \mathrm{~mL})$. To this solution, rac-lactide $(0.197 \mathrm{~g}, 1.37 \mathrm{mmol}$, 100 equiv vs. Zn) was added rapidly. The mixture was immediately stirred with a magnetic stirrer bar at $80{ }^{\circ} \mathrm{C}$ for $30 \mathrm{~min}$. Aliquots of the crude material were periodically sampled by pipette for determining the monomer conversion by ${ }^{1} \mathrm{H}$ NMR spectroscopy in $\mathrm{CDCl}_{3}$, from the integration (Int.) ratio Int.polymer/[Int.polymer + Int.monomer $]$, using the methyl hydrogen resonances for PLA at $\delta 1.49 \mathrm{ppm}$ and for LA at $\delta 1.16 \mathrm{ppm}$. The reaction was quenched with a solution of $\mathrm{H}_{2} \mathrm{O}$ in THF ( $c a .1 \mathrm{~mL}, 10 \mathrm{wt}-\%$ ), and the polymer was precipitated with an excess amount of methanol $(c a, 100 \mathrm{~mL})$. The polymer was then filtered and dried under vacuum to a constant weight. The microstructure of PLAs was determined by homodecoupling ${ }^{1} \mathrm{H}$ NMR spectroscopy (methine region) at $20{ }^{\circ} \mathrm{C}$ in $\mathrm{CDCl}_{3}$ on a Bruker $\mathrm{AC}$ 500 spectrometer.

General Procedure for Polymerization of $r a c-\beta$-Butyrolactone. In a typical experiment (Table 2, entry 2), in a glovebox, a Schlenk flask was charged with a solution of complex $2 \mathbf{c}(10.0 \mathrm{mg}, 11.6 \mu \mathrm{mol})$ in toluene $(1.1 \mathrm{~mL})$. To this solution, rac- $\beta$-butyrolactone (0.99 g, 1.16 mmol, 100 equiv vs. Zn) was added rapidly. The mixture was immediately stirred with a magnetic stirrer bar at $80{ }^{\circ} \mathrm{C}$ for $4.5 \mathrm{~h}$. The reaction was processed and workedup similarly to that described above for lactide polymerization. Monomer conversions were calculated from ${ }^{1} \mathrm{H}$ NMR spectra of the crude reaction mixtures in $\mathrm{CDCl}_{3}$, from the

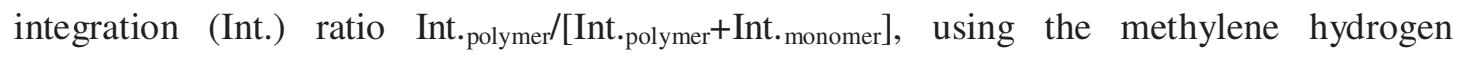


resonances for PHB at $\delta 1.49 \mathrm{ppm}$ and for BBL at $\delta 1.16 \mathrm{ppm}$. The microstructure of PHBs was determined by ${ }^{13} \mathrm{C}$ NMR spectroscopy (methylene region) at $20{ }^{\circ} \mathrm{C}$ in $\mathrm{CDCl}_{3}$ on a Bruker AC-500 spectrometer.

Crystal Structures Determination. Diffraction data for a, $\mathbf{b} \mathrm{CHCl}_{3}, \mathbf{c}, \mathbf{d}, \mathbf{e}^{\cdot} \mathrm{C}_{5} \mathrm{H}_{12}$ and complexes $1 \mathbf{a}^{\circ} 0.5 \mathrm{C}_{7} \mathrm{H}_{8}, \mathbf{1 c}, \mathbf{1} \mathbf{d}^{\cdot} 1.5 \mathrm{C}_{6} \mathrm{H}_{6}, \mathbf{2 c}, \mathbf{2 e}, \mathbf{3} \mathbf{c}^{\cdot} \mathrm{C}_{4} \mathrm{H}_{8} \mathrm{O}, \mathbf{3} \mathbf{e}^{\prime \prime}$ were collected at $100(2) \mathrm{K}$ using a Bruker APEX CCD diffractometer with graphite-monochromatized $\mathrm{MoK}_{\alpha}$ radiation $(\lambda=0.71073 \AA)$. A combination of $\omega$ and $\phi$ scans was carried out to obtain at least a unique data set. The crystal structures were solved by direct methods, remaining atoms were located from difference Fourier synthesis followed by full-matrix least-squares refinement based on F2 (programs SIR97 and SHELXL-97) ${ }^{22}$ with the aid of the WINGX program. ${ }^{23}$ In most cases, many hydrogen atoms could be found from the Fourier difference analysis. Other hydrogen atoms were placed at calculated positions and forced to ride on the attached atom. The hydrogen atom contributions were calculated but not refined. All non-hydrogen atoms were refined with anisotropic displacement parameters. The locations of the largest peaks in the final difference Fourier map calculation as well as the magnitude of the residual electron densities were of no chemical significance. Crystal data and details of data collection and structure refinement for proligands $\mathbf{a}, \mathbf{b} \cdot \mathrm{CHCl}_{3}, \mathbf{c}, \mathbf{d}, \mathbf{e} \cdot \mathrm{C}_{5} \mathrm{H}_{12}$ and complexes $\mathbf{1 a} \cdot 0.5 \mathrm{C}_{7} \mathrm{H}_{8}, \mathbf{1 c}$, $\mathbf{1 d} \cdot 1.5 \mathrm{C}_{6} \mathrm{H}_{6}, \mathbf{2} \mathbf{c}, \mathbf{2} \mathbf{e}, \mathbf{3} \mathbf{c} \cdot \mathrm{C}_{4} \mathrm{H}_{8} \mathrm{O}, \mathbf{3 e}$ '” are summarized in Tables $\mathrm{S} 2$ and $\mathrm{S} 3$.

Acknowledgments. We thank the University of Rennes 1 and CNRS for partial support of this work. We thank S. Sinbandhit (University of Rennes 1) for his help in conducting some NMR experiments.

Supporting Information available. Electronic supplementary information (ESI) available: Representative ${ }^{1} \mathrm{H}$ and ${ }^{13} \mathrm{C}\left\{{ }^{1} \mathrm{H}\right\}$ NMR spectra and crystallographic details of the prepared proligands, complexes and polymers. CCDC 1020173, 1020174, 1020175, 1020176, 
1020177, 1022410, 1020167, 1020168, 1020169, 1020170 and 1020171 contain the supplementary crystallographic data for compounds $\mathbf{a}, \mathbf{b} \cdot \mathrm{CHCl}_{3}, \mathbf{c}, \mathbf{d}, \mathbf{e}^{\cdot} \mathrm{C}_{5} \mathrm{H}_{12}$ and complexes 1a $0.5 \mathrm{C}_{7} \mathrm{H}_{8}, \mathbf{1 c}, \mathbf{1 d} \cdot 1.5 \mathrm{C}_{6} \mathrm{H}_{6}, \mathbf{2 c}, \mathbf{2 e}, \mathbf{3} \mathbf{c} \mathrm{C}_{4} \mathrm{H}_{8} \mathrm{O}, \mathbf{3 e}$ ', respectively. These data can be obtained free of charge from The Cambridge Crystallographic Data Centre via www.ccdc.cam.ac.uk/data_request/cif.

\section{References and Notes}

1 (a) Thomas, C. M. Chem. Soc. Rev. 2010, 39, 165. (b) Stanford, M. J.; Dove, A. P. Chem. Soc. Rev. 2010, 39, 486. (c) Carpentier, J.-F. Macromol. Rapid Commun. 2010, 31, 1696. (d) Dijkstra, P. J.; Du, H.; Feijen, J. Polym. Chem. 2011, 2, 520.

2 A particular case when two stereocontrol mechanisms are operational at the same time has been reported to result in gradient multiblock PLAs, see: Pilone, A.; Press, K.; Goldberg, I.; Kol, M.; Mazzeo, M.; Lamberti, M. J. Am. Chem. Soc. 2014, 136, 2940. Kirillov, E.; Roisnel, T.; Razavi, A.; Carpentier, J.-F. Organometallics 2009, 28, 5036.

4 For leading references to the use of group 13 complexes based on closely related $N$ and/or $O$-based tridentate dianionic ligands in the ROP of lactide/cyclic carbonates, see: (a) Hild, F.; Brelot, L.; Dagorne, S. Organometallics 2011, 30, 5457. (b) Hild, F.; Dagorne, S. Organometallics 2012, 31, 1189. (c) Hild, F.; Neehaul, N.; Bier, F.; Wirsum, M.; Gourlaouen, C.; Dagorne, S. Organometallics 2013, 32, 587.

(a) Grunova, E.; Kirillov, E.; Roisnel, T.; Carpentier, J.-F. Dalton Trans. 2010, 39, 6739. (b) Klitzke, J. S.; Roisnel, T.; Kirillov, E.; Casagrande Jr, O.; Carpentier, J.-F. Organometallics 2014, 33, 309. (c) Klitzke, J. S.; Roisnel, T.; Kirillov, E.; Casagrande Jr, O.; Carpentier, J.-F. Organometallics 2014, in press; dx.doi.org/ 10.1021/om401214q.

6 Related ligand systems have been recently employed for the preparation of complexes of magnesium, calcium and aluminum, see: (a) Yi, W.; Ma, H. Inorg. Chem. 2013, 52, 
11821. (b) Yi, W.; Ma, H. Dalton Trans. 2014, 43, 5200. (c) Gao, B.; Duan, R.; Pang, X.; Li, X.; Qu, Z.; Tang, Z.; Zhuang, X.; Chen, X. Organometallics 2013, 32, 5435. 5051. (b) Darensbourg, D. J.; Karroonnirun, O. Inorg. Chem. 2010, 49, 2360.

(a) Tay, B.-Y.; Wang, C.; Chia, S.-C.; Stubbs, L. P.; Wong, P.-K.; van Meurs, M. Organometallics 2011, 30, 6028. (b) Olson, J. A.; Boyd, R.; Quail, J. W.; Foley, S. R. Organometallics 2008, 27, 5333. (c) Nienkemper, K.; Kehr, G.; Kehr, S.; Frohlich, R.; Erker, G. J. Organomet. Chem. 2008, 693, 1572. Shannon, R. D. Acta Crystallogr., Sect. A 1976, 32, 751.

(a) Procopio, L. J.; Carroll, P. J.; Berry, D. H. J. Am. Chem. Soc.1994, 116, 177. (b) Herrmann, W. A.; Munck, F. C.; Artus, G. R. J.; Runte, O.; Anwander, R. Organometallics 1997, 16, 682. (c) Herrmann, W. A.; Eppinger, J.; Spiegler, M.; Runte, O.; Anwander, R. Organometallics 1997, 16, 1813. (d) Klimpel, M. G.; Gorlitzer, H. W.; Tafipolsky, M.; Spiegler, M.; Scherer, W.; Anwander, R. J. Organomet. Chem. 2002, 647, 236. (e) Sarazin, Y.; Roscsa, D.; Poirier, V.; Roisnel, T.; Silvestru, A.; Maron, L.; Carpentier, J.-F. Organometallics 2010, 29, 6569. (f) Rad'kov, V.; Trifonov, A.; Roisnel, T.; Carpentier, J.-F.; Kirillov, E. Eur. J. Inorg. Chem. 2014, in press; dx.doi.org/10.1002/ejic.201402362.

Complexes $\mathbf{4 f}-\mathbf{5 f}$ have two stereogenic centers $(\mathrm{N}, \mathrm{Ln})$ and also feature atropoisomery (planes of the naphthoxy and pyridine moieties) and should, in principle, exist as diastereomeric mixtures. We suggest that the non-observation of diastereomers in the NMR spectra of these complexes is due to very rapid site-exchange of the THF and amide ligands. Bochmann, M. Dalton Trans. 2009, 8667. 
Ay, S.; Ziegert, R. E.; Zhang, H.; Nieger, M.; Rissanen, K.; Fink, K.; Kubas, A.; Gschwind, R. M.; Brase, S. J. Am. Chem. Soc. 2010, 12899.

Zhang, C.; Wang, Z.-X. J. Organomet. Chem. 2008, 693, 3151.

Normand, M.; Dorcet, V.; Kirillov, E.; Carpentier, J.-F. Organometallics 2013, 32, 1694

17 Chapurina, Y.; Klitzke, J.; de L. Casagrande, O. Jr.; Awada, M.; Dorcet, V.; Kirillov, E.; Carpentier, J.-F. Dalton Trans. 2014, in press; dx.doi.org/10.1039/C4DT01206B.

Bouyahyi, M.; Sarazin, Y.; Casagrande, O. L., Jr.; Carpentier, J.-F. Appl. Organomet. Chem. 2012, 26, 681.

Eppinger, J.; Spiegler, M.; Hieringer, W.; Herrmann, W. A.; Anwander, R. J. Am. Chem. Soc.2000, 122, 3080.

Bochmann, M.; Bwembya, G.; Webb, K. J. Inorg. Synth., 1997, 31, 19.

Kowalski, A.; Duda, A.; Penczek, S. Macromolecules 1998, 31, 2114.

(a) Altomare, A.; Burla, M. C.; Camalli, M.; Cascarano, G.; Giacovazzo, C.; Guagliardi, A.; Moliterni, A. G. G.; Polidori, G.; Spagna, R. J. Appl. Cryst. 1999, 32, 115. (b) Sheldrick, G. M. SHELXS-97, Program for the Determination of Crystal Structures, University of Goettingen (Germany), 1997. (c)Sheldrick, G. M. SHELXL-97, Program for the Refinement of Crystal Structures, University of Goettingen (Germany), 1997. (d) Sheldrick, G. M. Acta Cryst. 2008, 64, 112.

Farrugia, L. J. J. Appl. Cryst. 1999, 32, 837. 
Table 1. ROP of racemic lactide promoted by complexes 1a, 1c, 1d, 2c, 2d, 2e, 3c, 3e', 4e and 4-6f. ${ }^{a}$

\begin{tabular}{|c|c|c|c|c|c|c|c|c|c|c|}
\hline Entry & Complex & $\begin{array}{l}{[\mathrm{LA}]_{0} /[\mathrm{M}]} \\
/[i \mathrm{PrOH}]_{0}{ }^{a}\end{array}$ & $\begin{array}{c}\text { Temp } \\
\left({ }^{\circ} \mathrm{C}\right)\end{array}$ & $\begin{array}{c}\underset{b}{\text { Time }} \\
\text { (h) } \\
\end{array}$ & $\begin{array}{c}\text { Conv. } \\
(\%) \\
\end{array}$ & $\begin{array}{c}M_{\mathrm{n}, \text { theo }}{ }^{d} \\
\left(\mathrm{~g} \cdot \mathrm{mol}^{-1}\right) \\
\left(\times 10^{3}\right)\end{array}$ & $\begin{array}{c}M_{\mathrm{n}, \mathrm{NMR}}{ }^{e} \\
\left(\mathrm{~g} \cdot \mathrm{mol}^{-1}\right) \\
\left(\times 10^{3}\right) \\
\end{array}$ & $\begin{array}{c}M_{\mathrm{n}, \mathrm{SEC}}{ }^{f} \\
\left(\mathrm{~g} \cdot \mathrm{mol}^{-1}\right) \\
\left(\times 10^{3}\right)\end{array}$ & $\bigoplus_{\mathrm{M}}{ }^{f}$ & $P_{\mathrm{r}}^{g}$ \\
\hline 1 & $1 \mathrm{a}$ & 100:1:0 & 25 & 24 & 0 & - & nd & - & - & 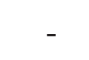 \\
\hline 2 & $1 \mathrm{a}$ & 100:1:0 & 100 & 48 & 0 & - & nd & - & - & \\
\hline 3 & $1 a$ & $100: 1: 5$ & 100 & 48 & 90 & 2.6 & 6.5 & 6.2 & 1.31 & 0.54 \\
\hline 4 & $1 \mathrm{a}$ & 1,000:1:5 & 100 & 144 & 23 & 6.6 & 9.6 & 9.9 & & 0.56 \\
\hline $5^{h}$ & $1 c$ & 100:1:0 & 60 & 4 & 91 & 13.1 & nd & 42.3 & 2.12 & 0.75 \\
\hline 6 & 1c & 100:1:0 & 80 & 0.5 & 92 & 13.2 & nd & & 1.70 & 0.65 \\
\hline 7 & 1d & 100:1:0 & 80 & 0.33 & 82 & 11.8 & nd & & 1.56 & 0.66 \\
\hline 8 & $2 c$ & 100:1:0 & 25 & 0.33 & 90 & 12.9 & nd & 11.7 & 1.68 & 0.72 \\
\hline 9 & $2 c$ & 250:1:0 & 25 & 0.5 & 84 & 30.3 & 10 & 27.7 & 1.91 & 0.73 \\
\hline 10 & $2 c$ & 500:1:0 & 25 & 0.66 & 57 & 41.1 & nd & 40.1 & 1.88 & 0.76 \\
\hline 11 & $2 c$ & 1,000:1:0 & 25 & 1 & 38 & 4.7 & nd & 58.8 & 1.92 & 0.74 \\
\hline 12 & $2 c$ & 2,000:1:0 & 25 & 1.75 & 77 & 222.2 & nd & 216.5 & 2.04 & 0.73 \\
\hline 13 & $2 c$ & 100:1:1 & 25 & 7 & 0 & - & - & - & - & - \\
\hline 14 & $2 c$ & 1,000:1:1 & 100 & 0.13 & 45 & 64.8 & nd & 30.6 & 1.46 & 0.65 \\
\hline 15 & $2 d$ & 100:1:0 & 25 & 0.5 & 36 & 5.2 & 5.7 & 5.4 & 1.32 & 0.75 \\
\hline 16 & $2 e$ & 100:1:0 & & 0.33 & 99 & 14.3 & nd & 13.8 & 1.11 & 0.71 \\
\hline 17 & $2 e$ & 500:1:0 & 25 & 1.33 & 85 & 61.2 & nd & 54.5 & 1.11 & 0.72 \\
\hline 18 & $2 e$ & 100:1:1 & 25 & 24 & 0 & - & - & - & - & - \\
\hline 19 & $2 e$ & $500 \cdot 1 \cdot 1$ & 25 & 24 & 0 & - & - & - & - & - \\
\hline 20 & $3 c$ & $100: 1: 0$ & 100 & 24 & 84 & 12.1 & nd & 29.9 & 1.54 & 0.50 \\
\hline 21 & 3 & 100:1:2 & 100 & 16 & 91 & 13.1 & 13.0 & 12.6 & 1.37 & 0.54 \\
\hline 22 & $3 e^{\prime}$ & 100:1:0 & 100 & 24 & 92 & 13.2 & 12.9 & 13.4 & 1.17 & 0.50 \\
\hline 23 & $3 e^{\prime}$ & 100:1:1 & 100 & 14 & 80 & 11.5 & 12.2 & 11.9 & 1.14 & 0.50 \\
\hline 24 & $4 e$ & 100:1:0 & 25 & 0.17 & 99 & 14.3 & nd & 27.5 & 2.13 & 0.80 \\
\hline $25^{h}$ & $4 e$ & 100:1:0 & 25 & 0.17 & 99 & 14.3 & nd & 33.9 & 2.11 & 0.79 \\
\hline 26 & $4 e$ & 500:1:0 & 25 & 0.5 & 96 & 69.2 & nd & 140.3 & 2.10 & 0.80 \\
\hline 27 & $4 e$ & 100:1:2 & 25 & 0.08 & $>99$ & 14.4 & 10.9 & 11.5 & 1.21 & 0.78 \\
\hline 28 & $4 e$ & $500: 1: 2$ & 25 & 0.25 & 92 & 66.3 & nd & 56.1 & 1.35 & 0.79 \\
\hline
\end{tabular}




\begin{tabular}{ccccccccccc}
29 & 4f & $100: 1: 0$ & 60 & 1 & 68 & 9.8 & 11.6 & 11.0 & 1.47 & 0.58 \\
30 & 5f & $100: 1: 0$ & 25 & 1.67 & 93 & 13.4 & 11.9 & 12.1 & 1.50 & 0.60 \\
$31^{g}$ & 5f & $100: 1: 0$ & 25 & 1 & 83 & 11.9 & nd & 15.2 & 1.54 & 0.69 \\
32 & 5f & $500: 1: 0$ & 25 & 6 & 44 & 31.7 & nd & 28.2 & 1.60 & 0.58 \\
33 & 5f & $100: 1: 1$ & 25 & 0.83 & 98 & 14.1 & 16.4 & 15.8 & 1.43 & 0.57 \\
34 & 6f & $100: 1: 0$ & 25 & 0.25 & 99 & 14.3 & nd & 14.2 & 1.98 & 0.69 \\
35 & 6f & $100: 1: 1$ & 25 & 0.13 & 98 & 14.2 & 13.8 & 13.3 & 1.57 & 0.68 \\
\hline
\end{tabular}

${ }^{a}$ Polymerization conditions otherwise stated: $[\mathrm{rac}-\mathrm{LA}]_{0}=1.0 \mathrm{M}$, solvent $=$ toluene. ${ }^{b}$ Reaction times were not necessarily optimized. ${ }^{c}$ Monomer conversion determined by ${ }^{1} \mathrm{H}$ NMR spectroscopy $\left(\mathrm{CDCl}_{3}, 298 \mathrm{~K}\right)$. Theoretical molecular weight calculated using $M_{\mathrm{n} \text {,theo }}=\operatorname{conv}(\mathrm{LA}) \times[\mathrm{rac}-\mathrm{LA}]_{0} /[\mathrm{M}$ or $i \mathrm{PrOH}] \times M_{\mathrm{LA}} \cdot{ }^{e}$ Determined by ${ }^{1} \mathrm{H}$ NMR spectroscopy. ${ }^{f}$ Experimental molecular weight determined by SEC $v s$. polystyrene standards and corrected by a factor of $0.58 ; \bigoplus_{\mathrm{M}}=M_{\mathrm{w}} / M_{\mathrm{n}} .{ }^{g} P_{\mathrm{r}}$ is the probability of racemic linkage between monomer units, as determined from the methine region of the homonuclear decoupled ${ }^{1} \mathrm{H}$ NMR spectrum. ${ }^{h}$ Carried out in THF. 
Table 2. ROP of racemic $\beta$-butyrolactone promoted by complexes $2 \mathbf{c}, \mathbf{2 e}, \mathbf{3 c}, 3 \mathbf{3}$ ', $4 \mathbf{e}$ and 4-6f. ${ }^{a}$

\begin{tabular}{|c|c|c|c|c|c|c|c|c|c|}
\hline Entry & Complex & $\begin{array}{l}{[\mathrm{BL}]_{0} /[\mathrm{M}]} \\
/[i \mathrm{PrOH}]_{0}{ }^{a}\end{array}$ & $\begin{array}{l}\text { Temp } \\
\left({ }^{\circ} \mathrm{C}\right)\end{array}$ & $\begin{array}{c}\text { Time }^{b} \\
\text { (h) }\end{array}$ & $\begin{array}{c}\text { Conv. }{ }^{c} \\
(\%)\end{array}$ & $\begin{array}{c}M_{\mathrm{n}, \text { theo }}{ }^{d} \\
\left(\mathrm{~g} \cdot \mathrm{mol}^{-1}\right) \\
\left(\times 10^{3}\right)\end{array}$ & $\begin{array}{c}M_{\mathrm{n}, \mathrm{SEC}}{ }^{e} \\
\left(\mathrm{~g} \cdot \mathrm{mol}^{-1}\right) \\
\left(\times 10^{3}\right)\end{array}$ & $\bigoplus_{\mathrm{M}}^{e}$ & $P_{\mathrm{r}}^{g}$ \\
\hline 1 & $2 c$ & 100:1:0 & 25 & 24 & 0 & - & - & - & - \\
\hline 2 & $2 c$ & 100:1:0 & 80 & 4.5 & $>99$ & 8.6 & 19.2 & 1.22 & nd \\
\hline 3 & $2 c$ & 500:1:0 & 60 & 14 & 70 & 30.1 & 39.3 & 1.07 & 0.56 \\
\hline 4 & $2 c$ & 500:1:0 & 80 & 19 & $>99$ & 43.0 & 55.9 & 1.07 & 0.56 \\
\hline $5^{h}$ & $2 c$ & $500: 1: 0$ & 80 & 28 & 52 & 22.4 & 25.6 & 13 & 0.56 \\
\hline 6 & $2 e$ & 100:1:0 & 60 & 4 & 85 & 7.3 & 15. & 1.23 & 0.50 \\
\hline 7 & $3 c$ & $100: 1: 0$ & 60 & 24 & 0 & - & & - & - \\
\hline 8 & $3 c$ & $100: 1: 2$ & 100 & 24 & 0 & - & & - & - \\
\hline 9 & $3 e^{\prime}$ & 100:1:0 & 100 & 24 & 0 & & - & - & - \\
\hline 10 & $4 e$ & $100: 1: 0$ & 25 & 0.08 & 73 & 6.3 & $289.3^{f}$ & $1.54^{f}$ & 0.56 \\
\hline 11 & $4 f$ & 100:1:0 & 60 & 24 & & - & - & - & - \\
\hline 12 & $5 f$ & 100:1:0 & 25 & & aces & nd & nd & nd & nd \\
\hline 13 & $5 f$ & 100:1:0 & 25 & 24 & 97 & 8.3 & 13.1 & 1.89 & 0.42 \\
\hline 14 & $6 f$ & 100:1:0 & 25 & 24 & 81 & 6.9 & 11.1 & 1.48 & 0.66 \\
\hline
\end{tabular}

${ }^{a}$ All reactions performed with $[\mathrm{rac}-\mathrm{BL}]_{0}=1.0 \mathrm{M} .{ }^{b}$ Reaction times were not necessarily optimized. ${ }^{c} \mathrm{BL}$ conversion to PHB determined by ${ }^{1} \mathrm{H}$ NMR spectroscopy $\left(\mathrm{CDCl}_{3}, 298 \mathrm{~K}\right)$ on the crude reaction mixture. ${ }^{d}$ Theoretical molecular weight calculated using $M_{\mathrm{n}, \text { theo }}=\operatorname{conv}(\mathrm{BL}) \times[\mathrm{rac}-\mathrm{BL}]_{0} /[\mathrm{M}$ or $i \mathrm{PrOH}] \times M_{\mathrm{BL}}$. Experimental (uncorrected) molecular weight determined by SEC in THF; $\bigoplus_{\mathrm{M}}=M_{\mathrm{w}} / M_{\mathrm{n}}$. ${ }^{f}$ Experimental (uncorrected) molecular weight determined by $\mathrm{SEC}$ in $\mathrm{CHCl}_{3} ; \bigoplus_{\mathrm{M}}=M_{\mathrm{w}} / M_{\mathrm{n}} .{ }^{g} P_{\mathrm{r}}$ is the probability of racemic linkage between monomer units and is determined by ${ }^{13} \mathrm{C}\left\{{ }^{1} \mathrm{H}\right\}$ NMR spectroscopy. ${ }^{h}$ Carried out in THF. 
n

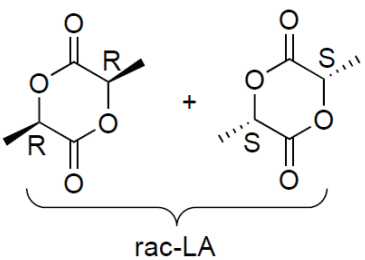

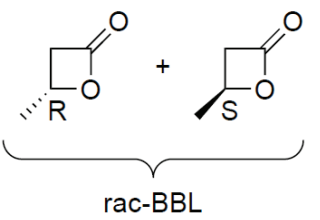

toluene

$25-100^{\circ} \mathrm{C}$

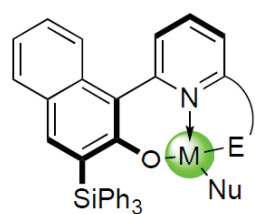

$\mathrm{E}=\mathrm{O}, \mathrm{N}$ $\mathrm{M}=\mathrm{Zn}$ Sc, Y, La Sc, Y, La

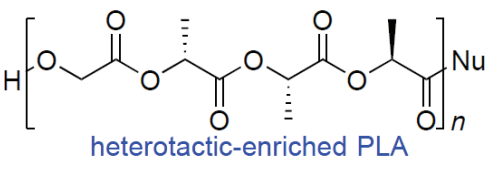
( $P_{\mathrm{r}}$ up to 0.80 )

TOF up to $1840 \mathrm{~mol} \cdot \mathrm{mol}^{-1} \cdot \mathrm{h}^{-1}$

toluene or THF

$25-100^{\circ} \mathrm{C}$

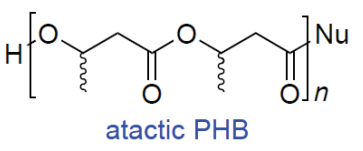

TOF up to $900 \mathrm{~mol} \cdot \mathrm{mol}^{-1} \cdot \mathrm{h}^{-1}$ 


\section{Highlights:}

- New tridentate ortho- $\mathrm{Ph}_{3} \mathrm{Si}$-substituted naphthol-pyridine ligands were synthesized

- Zn, Al, Y and La complexes were prepared

- Some of these complexes exhibit high activity in ROP of lactide and $\beta$-butyrolactone

- Good molecular weight control and narrow distributions are achieved 